\title{
Análise do Transporte de Soja, Milho e Farelo de Soja na Hidrovia Tietê-Paraná
}

\author{
João Carlos Vianna de Oliveira \\ Engenheiro Agrônomo
}

Orientador: Prof. Dr. José Vicente Caixeta Filho

Dissertação apresentada à Escola Superior de Agricultura "Luiz de Queiroz", Universidade de São Paulo, para obtenção do título de Mestre em Ciências, Área de Concentração: Economia Aplicada.

Piracicaba

Estado de São Paulo - Brasil

Outubro - 1996 
Dados Internacionais de Catalogação na Publicação (CIP) DIVISÃo DE BIBLIOTECA E DOCUMENTAÇÃO - Campus "Luiz de Queiroz"/USP

Oliveira, João Carlos Vianna de

Análise do transporte de soja, milho e farelo de soja na hidrovia Tietê-Paraná $/$ Jožo Carlos Vianna de Oliveira. - - Piracicaba, 1996.

136 p. : il.

Dissertação (mestrado) - Escola Superior de Agricultura Luiz de Queiroz, 1996.

Bibliografia.

1. Cultura agricola - Transporte fluvial - Estudo de caso 2. Hidrovia Tietê-

Paraná 3. Transporte fluvial - Análise I. Titulo 


\title{
Análise do Transporte de Soja, Milho e Farelo de Soja na Hidrovia Tietê-Paraná
}

\author{
João Carlos Vianna de OLIVEIRA
}

Aprovada em : 04.12.97

Comissão julgadora:

Prof. Dr. José Vicente Caixeta Filho

Prof. Dr. Geraldo Sant'Ana Camargo de Barros

Prof. Dr. Fernando Seixas

\section{ESALQ/USP}

ESALQ/USP

ESALQ/USP

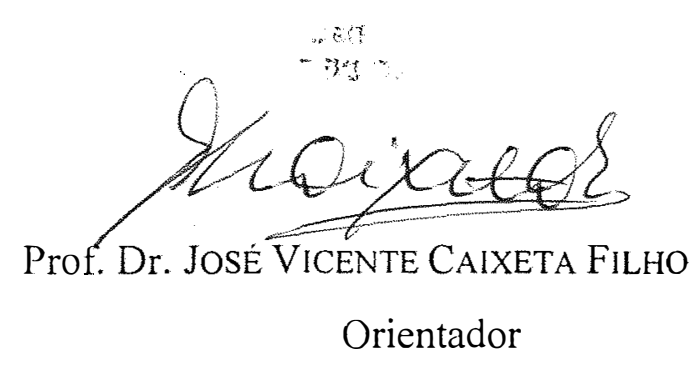


A minha esposa e filho

Eleonora e Danilo

Aos meus pais e irmãos

Sirley, José Carlos

Márcia, Alexandre e Eduardo

A minha avó

Sebastiana (in memorian) 


\section{Agradecimentos}

Ao Prof. José Vicente Caixeta Filho que além de excelente orientador é um grande amigo.

Aos Amigos da turma de mestrado que compartilharam as alegrias e dificuldades vividas durante o curso.

Aos Professores do Departamento de Economia e Sociologia Rural, que transmitiram conhecimento e exemplo de trabalho.

Aos funcionários do Departamento, que com esforço e dedicação nos auxiliaram em todos os instantes.

As empresas que gentilmente nos receberam e forneceram as informações essenciais para a realização desse trabalho.

A CAPES, que com o seu financiamento, permitiu a dedicação integral ao curso. 


\section{SUMÁRIO}

Página

LISTA DE FIGURAS _................................................................. vii

LISTA DE TABELAS ................................................................. ix

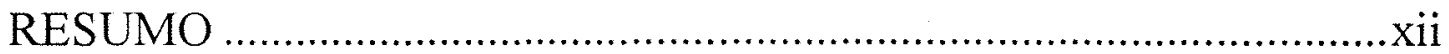

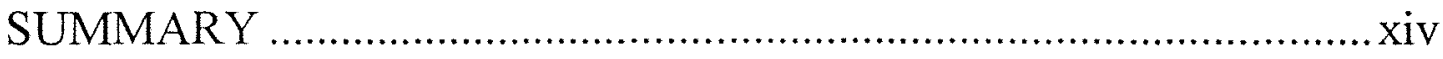

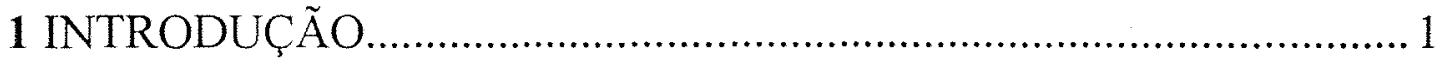

$1.1 \mathrm{O}$ problema e sua importância ....................................................2

2 COMERCIALIZAÇÃO, DIVISÃO MODAL E TRANSPORTE

HIDROVIÁRIO ................................................................ 8

2.1 Características da atividade de transporte ................................. 13

2.2 Estrutura da matriz de transporte .......................................... 15

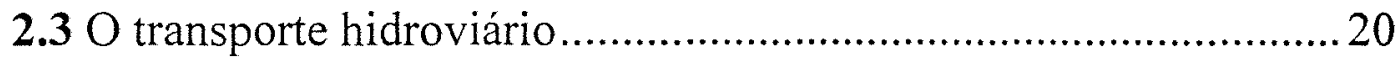

2.3.1 Situação na Europa ........................................................... 21

2.3.2 Situação nos EUA .........................................................23

2.3.3 Situação no Brasil ......................................................... 25

2.3.4 Hidrovia Tietê-Paraná................................................. 28

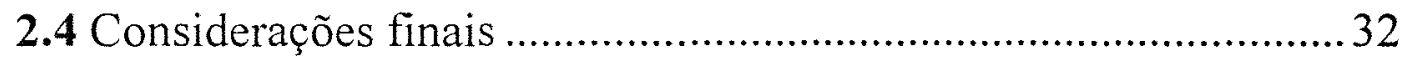

3 ARCABOUÇO TEÓRICO PARA A MODELAGEM DO

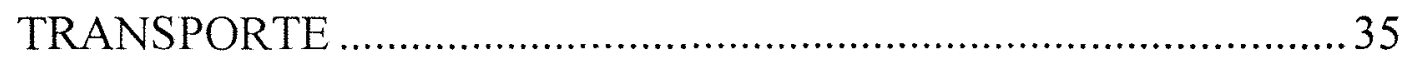

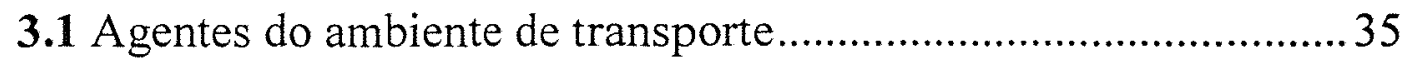

3.2 Prestador do serviço de transporte............................................. 37

3.3 Usuário do serviço de transporte. ............................................ 41 


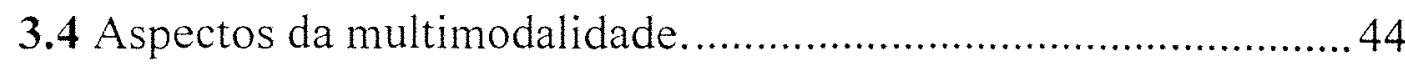

3.5 Análise da demanda por transporte. ............................................. 46

3.5.1 Estrutura de modelagem microeconômica. ......................... 47

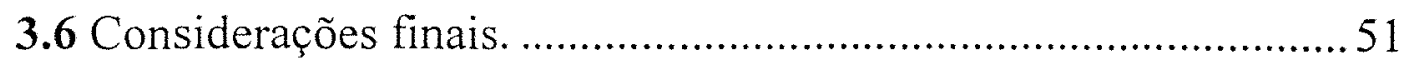

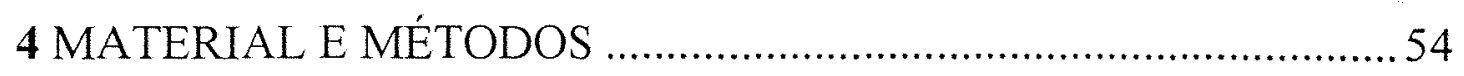

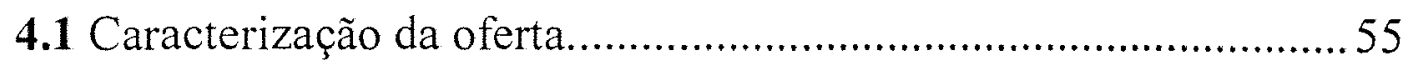

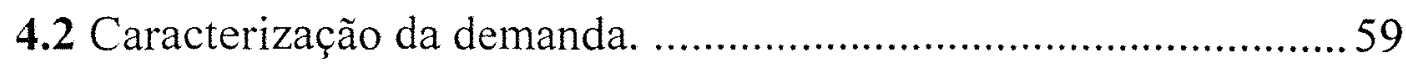

4.3 Verificação da competitividade do transporte hidroviário.............60

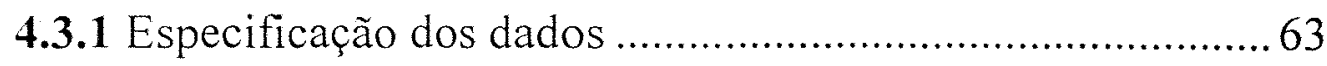

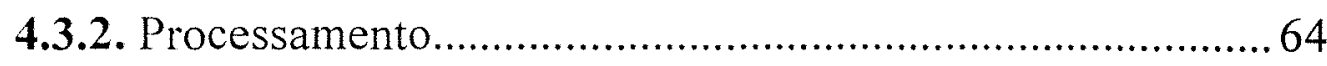

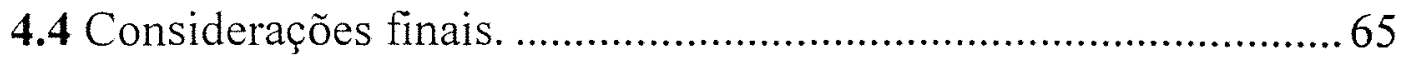

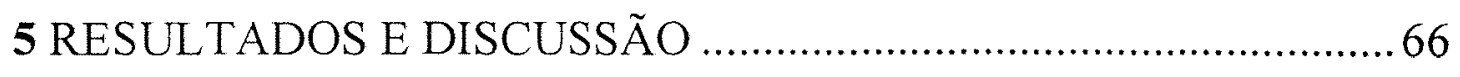

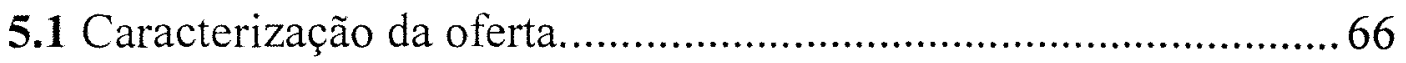

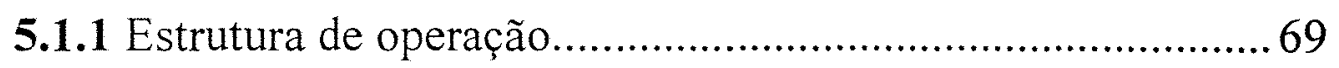

5.1.2 Características do transporte realizado .................................. 71

5.1.3 Conduta em relação ao usuário............................................... 72

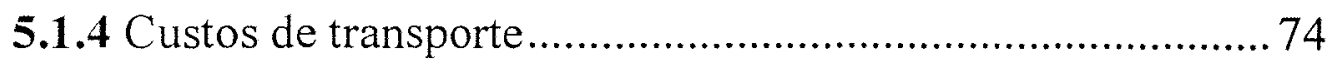

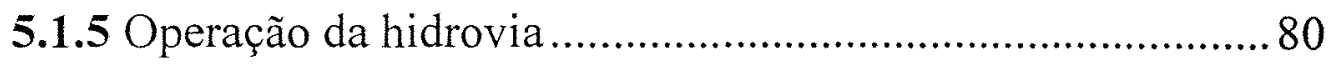

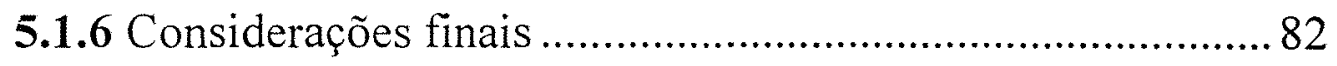

5.2 Demanda pelo transporte hidroviário. ........................................... 83

5.2.1 Soja em grão para exportação.............................................. 86

5.2.2 Soja em grão como matéria-prima da indústria .................... 88

5.2.3 Farelo de soja ..................................................................

5.2.4 Milho em grão …………………………………………..... 94 
5.2.5 Considerações finais ...................................................95

5.3 Verificação da competitividade do transporte hidroviário...........96

5.3.1 Análise das rotas com destino ao porto de Santos ............. 98

5.3.2 Análise das rotas com destino a algumas cidades do

Estado de São Paulo.......................................................... 101

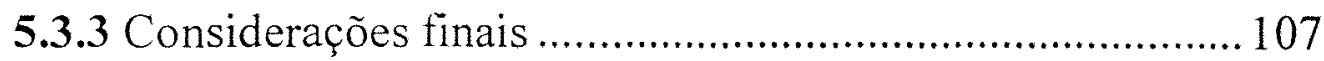

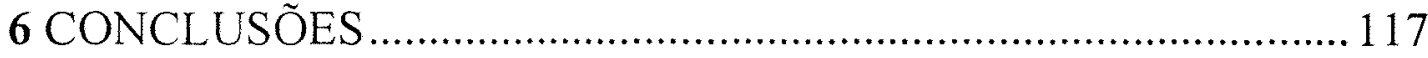

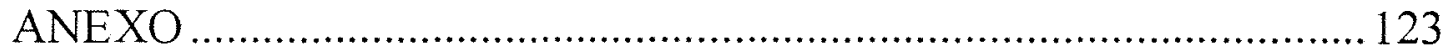

REFERÊNCIAS BIBLIOGRÁFICAS........................................... 129

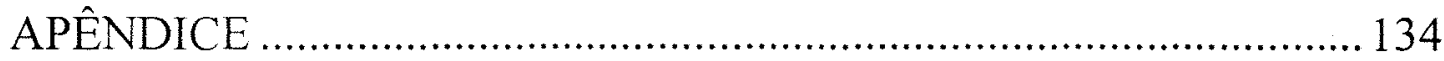




\section{LISTA DE FIGURAS}

1.1 Quantidade transportada por produto na hidrovia Tietê-Paraná durante os anos de 1991 a 1995

1.2 Evolução do transporte de soja em grão, milho em grão e farelo de soja, na hidrovia Tietê-Paraná, no período de 1991 a 1995.

2.1 Representação esquemática da cadeia agroindustrial do milho 8

2.2 Representação esquemática dos canais de comercialização da indústria brasileira de soja

2.3 Localização, trechos navegáveis, terminais e eclusas da hidrovia Tietê-Paraná...... 30

2.4 Esquema do Estado de São Paulo, mostrando o paralelismo das estradas de ferro com relação à hidrovia Tietê-Paraná

2.5 Esquema do Estado de São Paulo, mostrando o paralelismo das rodovias com relação à hidrovia Tietê-Paraná

2.6 Esquema do comboio Tietê-Paraná, elaborado com base nas especificações da CESP

3.1 Competição entre duas modalidades de transporte, dada a variação dos custos fixos.

3.2 Representação de um modelo de rede formado por 5 nós e $6 \operatorname{arcos}$ de interconexão

4.1 Diagrama de fluxo de informações do modelo proposto

5.1 Comportamento do custo unitário de transporte em função do número de viagens realizadas por ano, por embarcação, considerando-se diferentes porcentagens de carregamento

5.2 Movimentação mensal de cargas eclusadas, na hidrovia Tietê-Paraná, de janeiro de 1992 a abril de 1996

5.3 Número de embarcações eclusadas, na hidrovia Tietê-Paraná, por mês durante o ano de 1995 
5.4 Movimentação mensal de cargas eclusadas por produto na hidrovia TietêParaná, período de janeiro de 1996 a junho de 1996

5.5 Exportações brasileiras de soja em grão, quantidades ( $\mathrm{t}$ ) e preços (US\$/t), período de janeiro de 1994 a outubro de 1995

5.6 Exportações brasileiras de farelo de soja, quantidades $(\mathrm{t})$ e preços (US\$/t), período de janeiro de 1994 a outubro de 1995

5.7. Esquema mostrando os pontos de origem, destino (porto de Santos) e as alternativas de transporte disponiveis

5.8 Esquema mostrando os pontos de origem (Rio Verde-GO e São Simão-GO), as cidades de destino no Estado de São Paulo e as alternativas de transporte disponíveis

5.9 Variação da diferença percentual entre a alternativa multimodal e a unimodal rodoviária, com relação à alteração do custo de transbordo

5.10 Variação da diferença percentual entre a alternativa multimodal e a unimodal rodoviária, com relação à alteração do custo de transbordo, para cada alternativa de transporte

5.11 Comportamento da variação da diferença de custo entre as alternativas multimodais e unimodal rodoviária, com relação a alteração da distância entre essas duas alternativas

5.12 Comportamento geral dos valores de frete (US\$/t) das alternativas multimodais e da unimodal rodoviária, com relação à distância da unimodal rodoviária

5.13 Comportamento geral dos valores de frete (US\$/t) da alternativa multimodal e da unimodal rodoviária, com relação à distância da unimodal rodoviária, para cada alternativa de transporte 


\section{LISTA DE TABELAS}

Página

1.1 Quantidades estimadas (hipótese pessimista) e realizada de cargas transportadas pela hidrovia, para o ano de 1995 ..................................................................... 4

2.1 Balanço das produções estaduais de milho para a safra de 1994 ............................. 9

2.2 Principais estados produtores de soja e as respectivas capacidades ativas de industrialização da soja para o ano de 1993 .......................................................... 12

2.3 Principais portos brasileiros de exportação e as respectivas quantidades e porcentagens exportadas de soja em grão e farelo de soja no ano de 1992 ........... 13

2.4 Comparação geral das modalidades de transporte nos EUA................................... 16

2.5 Carga transportada, por modalidade nos EUA. 1993 ……………………........... 17

2.6 Composição do momento de transporte para os EUA, 1993 .................................... 18

2.7 Divisão modal (\%), segundo o momento de transporte $(\mathrm{t} . \mathrm{km})$, para países

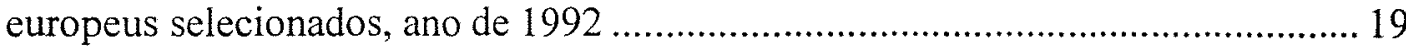

2.8 Quantidades de mercadorias movimentadas exclusivamente por transporte fluvial no ano de 1985, em alguns países da Europa .......................................... 22

2.9 Quantidade transportada por hidrovias norte-americanas no ano de 1993 .............. 24

2.10 Distâncias navegáveis com profundidade mínima de $2,5 \mathrm{~m}$, para os rios e

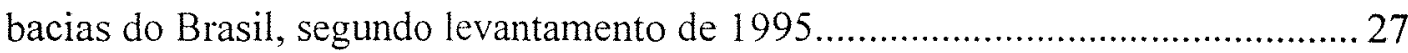

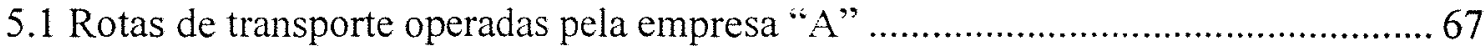

5.2 Rotas e produtos transportados pelas empresas " $\mathrm{B}$ " $\mathrm{e}$ "C" $\mathrm{C}$........................................68

5.3 Tempo de viagem para as principais rotas de transporte utilizadas pelas

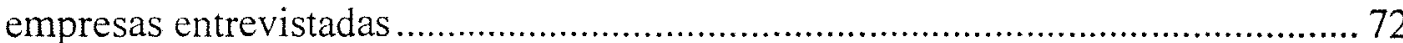

5.4 Número de viagens possiveis do comboio simples, por trecho de operação, segundo as condições vigentes no ano de 1996 ..................................................... 75

5.5 Parâmetros básicos adotados no cálculo dos custos de transporte ............................ 75 
5.6 Valores monetários adotados no cálculo dos custos de transporte...........................76

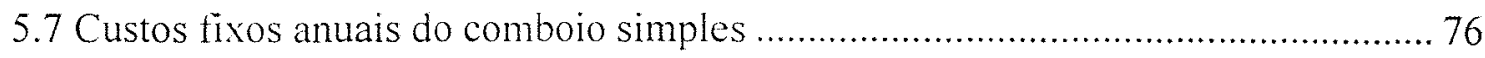

5.8 Recursos consumidos pelo comboio simples para a viagem entre São Simão e

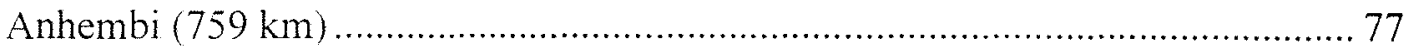

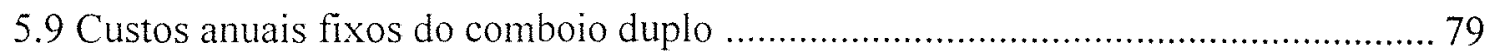

5.10 Recursos consumidos pelo comboio duplo para a viagem entre São Simão e

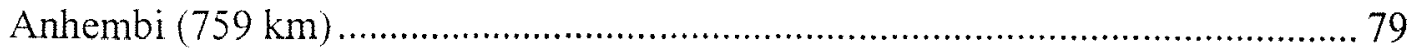

5.11 Tempo médio de paralização das eclusas das principais hidrovias dos EUA (1995)

5.12 Equação expressando a relação do valor do frete rodoviário (em US\$/t) com a distância $(\mathrm{km})$ para os produtos soja, milho e farelo de soja. transportados no período de outubro de 1993 a outubro de 1996

5.13 Resultados do processamento das rotas, considerando os custos associados com o comboio simples e destino Santos-SP

5.14 Resultados do processamento das rotas, considerando os custos associados com o comboio duplo e destino Santos-SP

5.15 Resultados do processamento das rotas, considerando os custos associados com o comboio simples e origem Rio Verde-GO

5.16 Resultados do processamento das rotas, considerando os custos associados com o comboio duplo e origem Rio Verde-GO

5.17 Resultados do processamento das rotas, considerando os custos associados com o comboio simples e origem São Simão-GO

5.18 Resultados do processamento das rotas, considerando os custos associados com o comboio duplo e origem São Simão-GO.

5.19 Diferença percentual média do custo das alternativas multimodais com relação à alternativa rodoviária. para as condições consideradas do transporte hidroviário e rotas com destino a Santos.... 
5.20 Diferença percentual média do custo das alternativas multimodais com relação à alternativa rodoviária, para as condições consideradas do transporte hidroviário e rotas com destino a algumas cidades do Estado de São Paulo 108

5.21 Diferença percentual média do custo das alternativas multimodais com relação à alternativa rodoviária, segundo os terminais hidroviários de descarga.

Anexo

1 Distâncias referentes às origens e destinos, por alternativa multimodal e unimodal rodoviária, com destino à Santos

2 Distâncias referentes às origens e destinos, por alternativa multimodal e unimodal rodoviária.....

3 Valores calculados para o custo unitário de transporte hidroviário (US\$/t.km) para o comboio simples de $2.200 \mathrm{t}$

4 Valores calculados para o custo unitário de transporte hidroviário (US\$/t.km) para o comboio duplo de $4.400 t$ 


\title{
Análise do Transporte de Soja, Milho e Farelo de Soja na Hidrovia Tietê-Paraná
}

\author{
Autor: JOÃO CARLOS VIANNA DE OLIVEIRA \\ Orientador: Prof. JOSÉ VICENTE CAIXETA FILHO
}

\section{RESUMO}

A utilização do transporte hidroviário de soja e milho no Brasil e no caso específico da hidrovia Tietê-Paraná, ainda encontra-se bastante incipiente, mesmo considerando-se a importância do serviço de transporte na comercialização desses produtos. Desta forma, o principal propósito deste trabalho foi analisar o transporte hidroviário de soja, milho e farelo de soja, com atenção especial às firmas envolvidas, procurando apresentar os elementos limitadores de uma maior utilização dessa alternativa de transporte.

Foi então delineado um estudo de caso, baseado em uma pesquisa exploratóriadescritiva com abordagens quantitativas e qualitativas sobre os prestadores do serviço de transporte hidroviário e sobre os demandantes desse serviço. Também foi realizada a avaliação da competitividade da alternativa hidroviária, utilizando-se o modelo de rede.

Pela caracterização da oferta do serviço de transporte hidroviário foi possível verificar os mais importantes elementos dessa atividade. Foi verificada uma significativa influência do tipo de embarcação (comboio simples ou duplo) e do nível de utilização do equipamento (número de viagens e porcentagem de carregamento) sobre os 
custos de transporte. Dois tipos básicos de empresas de transporte hidroviário foram encontrados, as que tem como atividade fim o transporte hidroviário e as que internalizaram essa atividade. O sistema de operação da hidrovia também foi um elemento influenciador da atividade de transporte. Três tipos principais de influência foram encontrados, o período de fechamento de eclusas, as taxas de utilização da hidrovia, e as restrições à navegação, que foram considerados prejudiciais em algum aspecto à competitividade da atividade de transporte hidroviário.

Os demandantes basicamente são empresas ligadas com a comercialização de soja e milho em grão e indústrias produtoras de óleo de soja. As empresas de comercialização optaram pela internalização da atividade de transporte e as demais demandantes optaram por contratar o serviço de terceiros. A relação entre prestadores do serviço e demandantes, através de contratos de curto prazo, foi identificada como um fator negativo, que poderia aumentar o custo de transporte hidroviário pela incerteza de demanda.

A competitividade da alternativa multimodal, que inclui a hidrovia, não é totalmente incontestável, se apresentando dependente de uma série de variáveis, dentre elas o custo hidroviário, o tipo de alternativa multimodal disponível entre um determinado par origem/destino e o aumento da distância com relação ao transporte rodoviário. A alternativa multimodal que apresentou a melhor competitividade, com relação à alternativa unimodal rodoviária, foi a hidro-ferroviária, seguida da rodo-hidroferroviária. As demais apresentaram, na maioria dos casos, custos de transporte mais elevados que aqueles observados para o transporte rodoviário. Constatou-se que, dependendo do desempenho da empresa na gestão das variáveis influenciadoras do seu custo unitário de transporte (US\$/t.km) e em especial, da intensidade de utilização do equipamento, o serviço oferecido poderá ter graus variáveis de competitividade. 


\title{
Analysis of Transportation of Soybean, Corn and Soybean Meal in the Tietê- Paraná Waterway
}

\author{
Author: JOÃO CARLOS VIANNA DE OLIVEIRA \\ Supervisor: Prof. JOSÉ VICENTE CAIXETA FILHO
}

SUMMARY

The waterway transportation volume of soybean and corn in Brazil, and specially in the case of Tietê-Paraná waterway, is still very low, even considering the high importance of transport services to these products. In view of that, the main proposal of this study is to analyse the waterway transportation of soybean, corn and soybean meal, with special focus on the involved firms, trying to recognize the intensive utilization constraint factors of this transportation option.

To do that, a case study was designed, based on a exploratory research with quantitative and qualitative descriptions of waterway carriers, shippers and receivers. It was also conducted the competitiveness analysis of the waterway system against the truck-only transportation, through a network model.

The characterization of waterway transportation supply made possible the identification of the most important elements of this activity. It was noted the significant influence from the kind of tow ( 2 or 4 barges) and the level of equipment utilization (number of trips per year and the percentage of balanced loaded trips) over the 
transportation costs. Two types of waterway transportation companies were identified: the transport specialized companies and the others where the transport is just one part of their marketing activity. The waterway system operation was also an important element that influenced the transportation activity. Three main aspects were pointed out: the period in which locks are closed, the usage taxes, and the navigation constraints, that were considered prejudicial in some way to the waterway transportation competition.

The actual shippers that demanded the Tietê-Paraná waterway services were basically trading companies of soybean and corn, and soybean oil production companies. The trading companies were realizing that the waterway transportation and the other shippers were contracting these services from other transportation companies. The relationship between carrier and shipper by short-run contracts were recognized as a negative trade factor, that could increase the transportation costs of waterway by the demand uncertainty.

The competitiveness of multimodal options, that include the waterway, is not fully incontestable, been dependent on many factors, like the waterway costs, the type of multimodal option available between a par source/target pair, and the increase in distance compared to the road transportation mode. The multimodal option that showed the best competitiveness, compared to the truck option, was the water-railway, followed by the truck-water-railway. The other ones showed, in the majority of the cases, transportation costs greater than the observed for the trucks. It was also verified that the transportation company performance affected the different degrees of competitiveness of the transportation service. 


\section{INTRODUÇÃO}

A produção de grãos brasileira, por razões diversas, deslocou-se para as regiões mais interiores, se distanciando dos centros consumidores e dos portos. Sendo assim, os serviços de comercialização, e especialmente o transporte, têm se tornado um item importante na composição dos custos do produto nacional.

No caso da soja, Melo (1990) aponta o alto custo de transporte como um dos principais entraves ao desenvolvimento da produção daquele grão no Brasil Central. $\mathrm{O}$ valor do frete no ano de 1990 , para uma distância de $1.400 \mathrm{~km}$, era de US\$ $50 / \mathrm{t}$ no Brasil e US\$ 6,6/t nos EUA.

Ao se comparar a matriz de transporte de soja dos EUA e do Brasil, pode-se verificar a predominância do transporte hidroviário (mais barato) para o primeiro e do rodoviário (mais caro) para o segundo (Burnquist et al., 1994), o que tem sido utilizado por vários autores, como por exemplo, Ferreira et al. (1993), para explicar a grande diferença de custo de transporte entre os dois países.

Problemas estruturais também podem ser relacionados como os principais responsáveis pelo alto custo de transporte brasileiro. A falta de corredores de transporte multimodais, a precária estrutura de armazenagem e a não conjugação de cargas de retorno, são elementos que tornam o transporte de produtos agrícolas, especialmente de grãos, um componente de peso excessivo no custo final do produto.

Dentro desse contexto de importância do transporte para a agricultura, em especial para soja e milho produzidos nas regiões de fronteira, encontra-se a hidrovia Tietê-Paraná, uma alternativa de transporte de grãos, já explorada por algumas empresas, para o escoamento com destino aos mercados interno e externo.

Observa-se que, não obstante a necessidade por alternativas de transporte mais baratas ser incontestável, a utilização da modalidade hidroviária ainda encontra-se bem 
inferior à desejável, mesmo sendo consagradamente uma modalidade mais barata que a rodoviária.

Desta forma, existe a necessidade de um maior conhecimento sobre esta atividade de transporte hidroviário, em específico sobre as características das empresas já operantes e das empresas demandantes, de forma a se identificar os elementos influenciadores, os fatores limitantes e as perspectivas dessa alternativa de transporte em relação às outras disponíveis e já utilizadas.

O presente trabalho objetiva, avaliar o atual processo de transporte de soja em grão, milho em grão e farelo de soja na hidrovia Tietê-Paraná. buscando oferecer uma visão sistemática da realidade à luz da economia dos transportes.

Os objetivos especificos são:

- estabelecer a natureza da oferta de transporte hidroviário pela identificação dos custos e características do serviço oferecido:

- caracterizar os usuários dos serviços de transporte hidroviário de grãos;

- verificar a competitividade do transporte hidroviário em relação às outras modalidades disponiveis na região.

\subsection{0 problema e sua importância}

O transporte na hidrovia Tietê-Paraná tem ocorrido com maior concentração do volume de cargas de alguns produtos em particular. Esse detalhe pode ser melhor visualizado na Figura 1.1. 

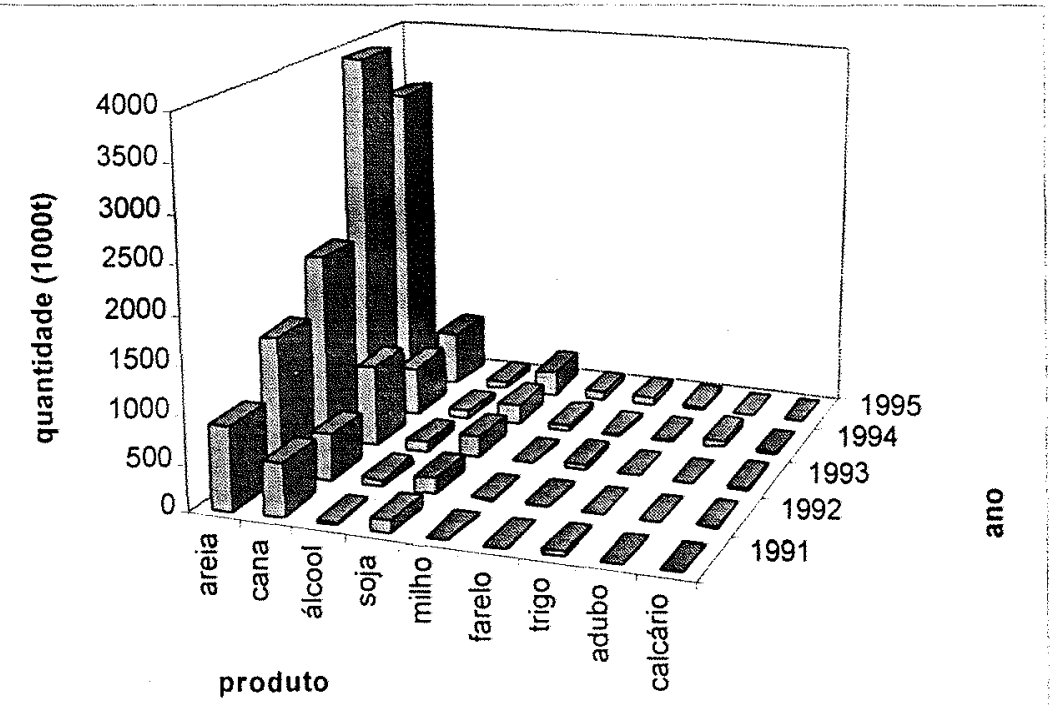

Figura 1.1 - Quantidade transportada por produto na hidrovia Tietê-Paraná durante os anos de 1991 a 1995 (Fonte: Companhia Energética de São Paulo CESPI).

O principal produto transportado nos últimos anos pela hidrovia tem sido a areia, cujo volume mais que triplicou (de 890 mil $\mathrm{t}$ em 1991 para 3315,6 mil t em 1995). No entanto, os produtos agrícolas, em relação à areia, representam uma pequena parcela do volume total transportado. Em 1995 a soja representou 5,7\% (252,9 mil t), o farelo de soja $1,76 \%(78,1$ mil t) e o milho $1,83 \%$ (81,1 mil t). Ao mesmo tempo, o grupo de insumos agrícolas (calcário e adubo), representam uma parcela ainda menor das movimentações, totalizando cerca de $0,2 \%$ da quantidade movimentada. A cana-de açúcar, por outro lado, é um produto de origem agrícola, que apresenta grandes volumes transportados na hidrovia Tietê-Paraná. No entanto, isto ocorre em uma situação particular, na qual uma usina de açúcar e álcool possui a unidade industrial e áreas produtivas localizadas junto à hidrovia, o que a diferencia da situação da soja e do milho que são produzidos em regiões não adjacentes à hidrovia.

${ }^{1}$ Dados fornecidos pela Diretoria de Hidrovias e Desenvolvimento Regional da Companhia Energética de São Paulo - CESP. 
A Companhia Energética de São Paulo (CESP) tem realizado estudos sobre projeções de cargas passíveis de serem movimentadas pela hidrovia. Esses estudos têm se fundamentado na verificação do potencial de produção e consumo das regiões de abrangência da hidrovia. Os principais produtos destacados nesses relatórios são grãos, farelos, fertilizantes, calcário agrícola, madeira, papel, carvão vegetal. álcool e derivados de petróleo.

No relatório da CESP (1992), previa-se para 1994-1995 o escoamento de 5 a 6 milhões de toneladas de grãos e farelos com destino aos centros consumidores e exportadores do Estado de São Paulo e Paraná. No entanto. verifica-se que esta quantidade foi superestimada. ao se defrontar com o que realmente foi transportado nesse periodo (319 mil t em 1994 e 439 mil t em $1995\left(\right.$ CESP$\left.^{2}\right)$ ).

Em relatório realizado pela empresa Themag Engenharia (1987), a partir de solicitação da própria CESP, também se nota a discrepância entre o real e o estimado. Os valores apresentados no relatório para as quantidades estimadas de cargas a serem absorvidas pela hidrovia são apresentados na Tabela 1.1. O relatório argumenta que as cargas seriam atraídas não somente em função dos baixos fretes, mas também em função das facilidades operacionais e principalmente da aceitação da hidrovia pelas indústrias. Analisando-se novamente esses fatores, percebe-se que suas contribuições não corresponderam ao esperado, refletindo-se nas discrepâncias entre as estimativas e a realidade.

Tabela 1.1 - Quantidades estimadas (hipótese pessimista) e realizadas de cargas transportadas pela hidrovia, para o ano de 1995.

\begin{tabular}{lccc}
\hline Produto & $\begin{array}{c}\text { Estimado } \\
(\mathbf{1 0 0 0})\end{array}$ & $\begin{array}{c}\text { Real } \\
(\mathbf{1 0 0 0} \mathbf{)}\end{array}$ & $\begin{array}{c}\text { Real/Estimado } \\
\mathbf{( \% )}\end{array}$ \\
\cline { 2 - 4 } Soja & 1200 & 253 & 21,10 \\
Mitho & 700 & 81 & 11,57 \\
Calcário & 700 & 8 & 1,14 \\
\hline Fonte: Themag Engenharia (1987) e CESP2
\end{tabular}

2 Dados fornecidos pela Diretoria de Hidrovias e Desenvolvimento Regional da Companhia Energética de São Paulo - CESP. 
Não é o caso de se discutir os procedimentos adotados em trabalhos anteriores, mas dadas as diferenças entre as previsões e a realidade. pode-se suspeitar que os baixos fretes, a facilidade de operação e a aceitação da hidrovia pelas indústrias não se efetivaram na intensidade esperada.

Toledo (1982), verificando as perspectivas do transporte hidroviário de calcário pela hidrovia Tietê-Paraná no Estado de São Paulo, constatou que esse transporte sofreria forte concorrência da modalidade rodoviária. Nas simulações realizadas pelo autor, constatou-se a perda de competitividade do transporte hidroviário quando este pressupunha a integração com segmentos rodoviários e quando se acrescentava a possibilidade de fretes de retorno para o transporte rodoviário. As principais conclusões foram: o transporte de calcário pela hidrovia não seria viável, pois a economia obtida não seria suficiente para atrair investimentos; o calcário só seria transportado pela hidrovia como carga de retorno de outros produtos; e a potencial competitividade seria ainda comprometida pelo fato da posição geográfica da hidrovia não coincidir com as regiões de maior consumo no Estado.

Toledo (1982) assinala, portanto, novos fatores influenciadores do volume de cargas da hidrovia, como o nível de investimento para se operar a atividade em relação à economia a ser obtida, a competição intensa com outra modalidade e o seu posicionamento geográfico.

Por outro lado, o transporte tem sido considerado um dos itens do custo de comercialização que mais tem prejudicado a competitividade da produção agrícola, em especial a de soja e a de milho. Ferreira et al. (1993), citando publicação da Abiove ${ }^{3}$, destacam que $74 \%$ do transporte de soja são realizados por rodovia, $23 \%$ por ferrovia e $3 \%$ por hidrovia. Argumentam ainda que esse padrão de distribuição modal é uma das explicações para o alto custo do transporte na comercialização desse produto. Sendo

\footnotetext{
3 Associação Brasileira de Indústrias de Óleos Vegetais. Evolução e perspectivas do mercado de soja e derivados. São Paulo, 1990.
} 
assim. a busca por alternativas mais baratas de transporte deveria ser esperada. o que no entanto nào se efetiva. Por exemplo. o volume de cargas transportado pela hidrovia Tietê-Paraná, considerada uma alternativa de baixo custo de transporte, não tem apresentado grande desenvolvimento.

Não obstante as discrepâncias observadas, algumas empresas têm acreditado no potencial econômico da hidrovia Tietê-Paraná, em específico na exploração do transporte de produtos agrícolas. Têm ocorrido investimentos na instalação de fábricas junto à hidrovia, na construção de terminais de carga e descarga e em comboios de transporte. Esse fato pode ser notado na evolução. discreta mas existente, do transporte dos produtos agrícolas, como mostra a Figura 1.2.

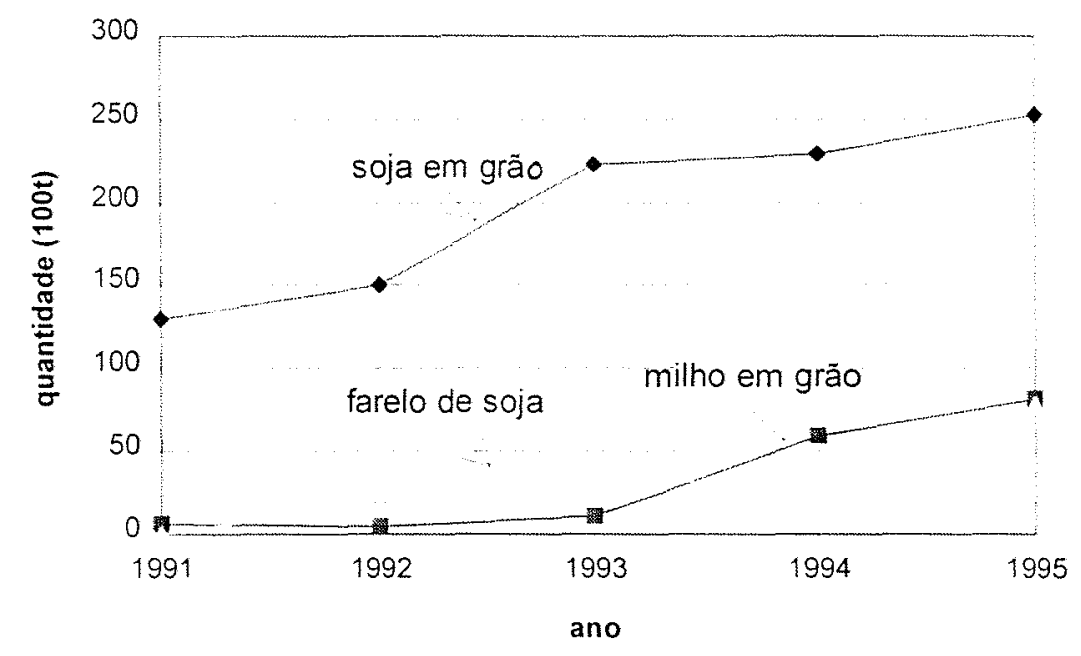

Figura 1.2 - Evolução do transporte de soja em grão, milho em grão e farelo de soja na hidrovia Tietê-Paraná, no período de 1991 a 1995 (Fonte: CESP4).

Nota-se. portanto, que a atividade de transporte na hidrovia Tietê-Paraná ainda busca os ajustamentos necessários para o seu pleno funcionamento. Os agentes

\footnotetext{
${ }^{4}$ Dados fornecidos pela Diretoria de Hidrovias e Desenvolvimento Regional da Companhia Energética de São Paulo - CESP.
} 
envolvidos estão buscando o seu ponto ótimo de operação, baseados nas experiências adquiridas no dia-a-dia da atividade e em informações de outros paises.

Sendo assim, este trabalho foi estruturado de maneira a oferecer um retrato da realidade da atividade de transporte de soja em grão, milho em grão e farelo de soja na hidrovia Tietê-Paraná. de forma a contribuir com o desenvolvimento dessa atividade. No capítulo 2 será apresentada uma revisão sobre a atividade de comercialização dos produtos estudados, sobre a divisão modal e sobre a atividade de transporte hidroviário no mundo, no Brasil e na hidrovia Tietê-Paraná. Ao capitulo 3 corresponderá uma revisão sobre os aspectos teóricos norteadores dos procedimentos a serem adotados para a condução dos objetivos do trabalho. No capítulo 4 será apresentado o método utilizado para a obtenção e análise dos dados. No capítulo 5 serão mostrados os resultados obtidos e será realizada a discussão com base na teoria discutida anteriormente. No capítulo 6 serão apresentadas as conclusões e recomendações do trabalho. 


\section{COMERCIALIZAÇÃO, DIVISÃO MODAL e TRANSPORTE HIDROVIÁRIO}

Os produtos considerados no presente trabalho são soja em grão, milho em grão e farelo de soja. A atenção específica sobre esses produtos justifica-se pela importância dos mesmos no mercado agrícola brasileiro; no peso do custo de transporte na comercialização e competitividade externa desses produtos; e no fato desses produtos serem típicos usuários do transporte hidroviário, pelo menos em outros países.

A produção brasileira de milho é basicamente voltada para o abastecimento interno, em específico para o suprimento das demandas para alimentação humana e animal. Segundo Troccoli (1995), a produção da safra de 94/95 foi de 37 milhões de te o consumo foi de 35 milhões de t. Na Figura 2.1 pode-se visualizar a cadeia agroindustrial do milho no mercado brasileiro.

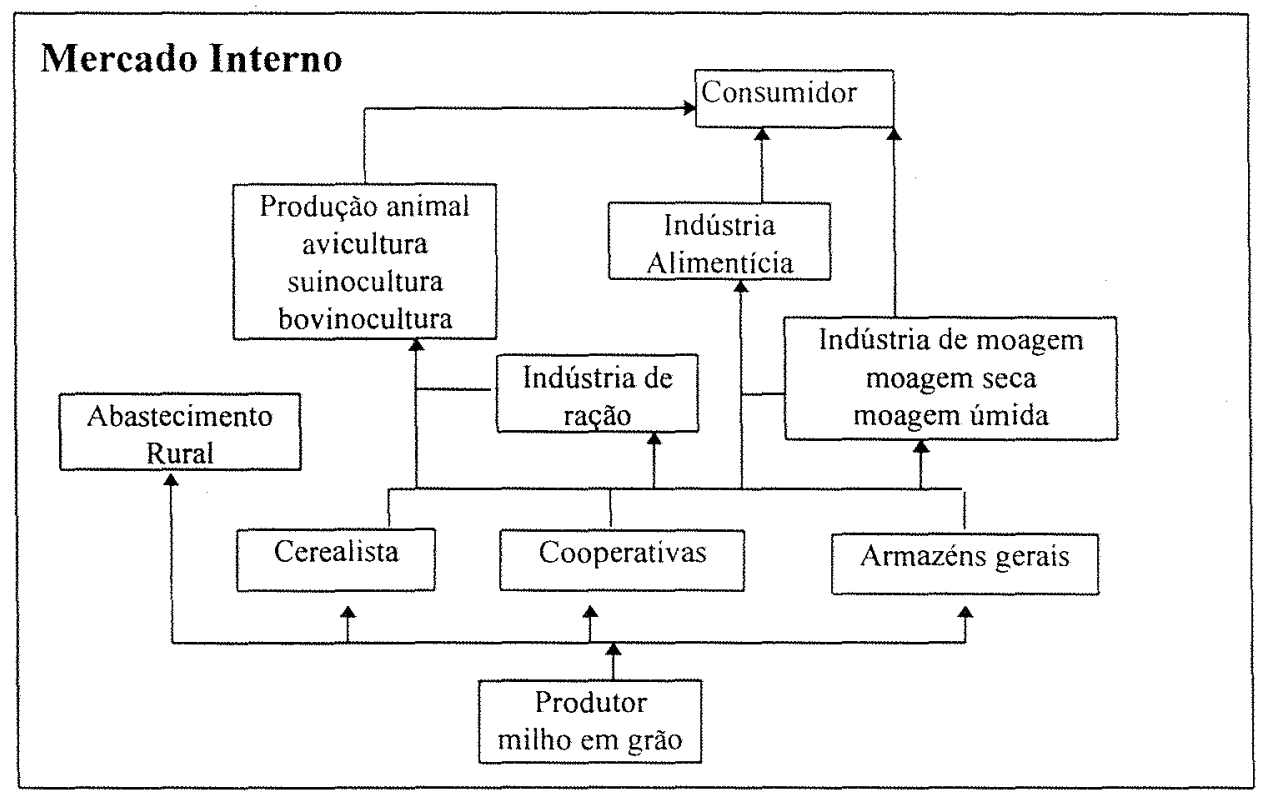

Figura 2.1 - Representação esquemática da cadeia agroindustrial do milho, adaptado de Souza (1995). 
Lima (1993) destaca que a maior parte do volume de milho consumido destina-se basicamente à alimentação animal, existindo uma estreita relação entre o mercado de carnes, especialmente de aves e suínos, com o mercado do milho. De acordo com Troccoli (1995), para produzir 21,897 milhões de t de ração em 1995, foram consumidos 12.494 milhões de $t$ de milho. Para o Estado de São Paulo, o maior consumidor de milho para elaboração de ração de aves, a Associação Paulista de Avicultura (APA) prevê o consumo de 2,73 milhões de t de milho em 1996, segundo dados publicados pela Revista Aves \& Ovos (1996).

De acordo com Souza (1995), os estados da Federação podem ser divididos entre importadores (SP e SC) e exportadores ( $\mathrm{PR}$ e GO). $\mathrm{Na}$ Tabela 2.1 pode ser visto o balanço da produção e consumo de milho nos estados brasileiros.

Tabela 2.1 - Balanço das produções estaduais de milho para a safra de 1994.

\begin{tabular}{lrrr}
\hline Estado & $\begin{array}{c}\text { Produção } \\
\text { (mil t) }\end{array}$ & $\begin{array}{c}\text { Consumo } \\
\text { (mil t) }\end{array}$ & $\begin{array}{r}\text { Balanço } \\
\text { (mil t) }\end{array}$ \\
\hline Paraná & 8594 & 5575 & 3020 \\
Rio Grande do Sul & 4744 & 4964 & -220 \\
Minas Gerais & 3810 & 3913 & -103 \\
Santa Catarina & 3303 & 4598 & -1295 \\
Goiás & 3136 & 2086 & 1050 \\
São Paulo & 3136 & 6246 & -3110 \\
Mato Grosso do Sul & 1200 & 550 & 650 \\
Mato Grosso & 1172 & 737 & 435 \\
Espírito Santo & 226 & 410 & -184 \\
Rio de Janeiro & 55 & 374 & -319 \\
Outros & 6798 & 9394 & -2596 \\
\hline Total & 33038 & 32600 & 438 \\
\hline Fonte: Souza(1995) & \multicolumn{3}{c}{}
\end{tabular}

O transporte é destacado como um elemento importante na comercialização do milho, em especial para as regiões produtoras mais distantes dos centros consumidores. Dados apresentados por FNP Consultoria (1996). mostram que o custo de transporte, 
para o Estado de Goiás. representa 54\% dos custos de pós-colheita ${ }^{5}$. o que aproximadamente representa de $6 \%$ a $10 \%$ do preço pago ao produtor. Soares \& Caixeta (1996) apresentam valores de 15\% a $20 \%$ do preço final do milho. como sendo o peso do transporte para uma distância de $600 \mathrm{~km}$. Santo et cl. (1994) destacam a diminuição da carga tributária e a melhoria do sistema de transporte como duas variáveis fundamentais para a garantia do futuro da produção de milho no Centro-Oeste. O autor cita a perda de competitividade do milho do Mato Grosso, comercializado no Nordeste, para o milho importado, como um exemplo do efeito do custo de transporte e da tributação.

Quanto à soja, o complexo agroindustrial dessa cultura é responsável por uma renda de exportações na ordem de US\$ 3,5 a 4 bilhões, segundo a FNP-Consultoria (1996). O Brasil é o segundo maior exportador de soja em grão, o maior exportador de farelo de soja e possui a segunda maior produção do mundo. Na safra de 93/94, o Brasil produziu 25 milhões de t, consumiu 19,7 milhões de t, exportou 5.5 milhões de $t$ de soja em grão e 9,5 milhões de $t$ de farelo, de acordo com dados da Revista Agroanalysis (1995) e FNP Consultoria (1996).

Com relação ao processo de comercialização da soja no Brasil, Aguiar (1990) destaca os canais de comercialização da indústria brasileira de soja, que podem ser visualizados na Figura 2.2.

Nota-se a existência de dois níveis divisórios da atividade de comercialização e processamento. O primeiro refere-se à comercialização da soja em grão, que é executado pelo agricultor, exportador ("trading"), cooperativa e indústria. O segundo refere-se à comercialização do óleo e do farelo de soja, onde os agentes envolvidos são os pecuaristas, atacadistas, supermercados e varejistas.

\footnotetext{
5 Os custos de pós-colheita incluem: transporte, recebimento. secagem, pré-limpeza, pesagem, descarga e taxa administrativa. Para o caso do Estado de Goiás. a distância média considerada da unidade produtiva até o armazém é de $80 \mathrm{~km}$.
} 


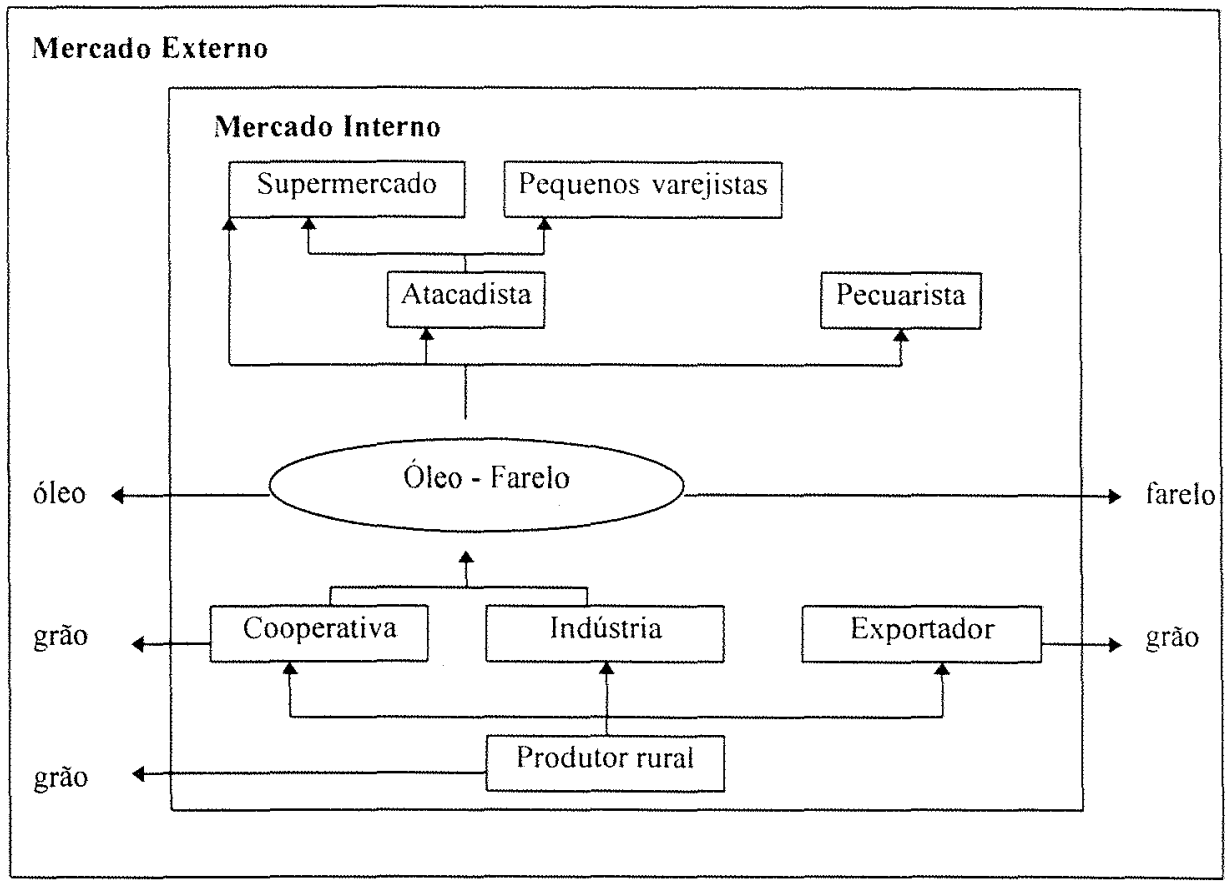

Figura 2.2 - Representação esquemática dos canais de comercialização da indústria brasileira de soja (Fonte: Aguiar, 1990).

Aguiar (1990) destaca que as vendas de soja em grão nas regiões de cultivo tradicional ocorrem por intermédio das cooperativas, que também realizam a exportação e, em alguns casos, o processamento. Por outro lado, nas regiões do Centro-Oeste, as vendas ocorrem diretamente do produtor para as indústrias.

O segundo nível refere-se à comercialização de óleo e farelo produzidos pelas indústrias esmagadoras. O óleo no mercado interno é repassado pelas indústrias para os atacadistas e varejistas; já para o mercado externo, as próprias indústrias realizam a exportação. O farelo é vendido no mercado interno, em sua maior parte, para a produção animal, onde será usado como ração. Aguiar (1990) salienta que a quantidade de farelo adquirida pelas fábricas de ração é bastante inferior em relação à adquirida pelos pecuaristas. Esse fato ocorre, segundo o autor, em função das vantagens econômicas da produção de ração no local de consumo. Quanto ao farelo destinado para o mercado externo, este também atende à demanda para a alimentação animal. Aguiar (1990) nota 
que a exportação de farelo de soja é realizada em sua maior parte pelas próprias indústrias.

A produção em função da capacidade de processamento de soja por estado pode ser visualizada na Tabela 2.2. Nota-se que os Estados do Paraná e São Paulo são os que apresentam o maior déficit entre a produção e a capacidade de processamento da soja. No entanto, deve-se destacar que a capacidade de processamento, segundo Estrazulas (1996), apresenta ociosidade próxima de 50\%.

Tabela 2.2 - Principais estados produtores de soja e as respectivas capacidades ativa de industrialização da soja para o ano de 1993.

\begin{tabular}{lccc}
\hline \multicolumn{1}{c}{ Estado } & $\begin{array}{c}\text { Produção }^{\mathrm{it}} \\
(\mathbf{1 . 0 0 0} \mathbf{~}) \\
{[\mathrm{A}]}\end{array}$ & $\begin{array}{c}\text { Capacidade ativa de } \\
\text { industrialização }(\mathbf{1 . 0 0 0 t})^{\mathbf{b}}\end{array}$ & $\begin{array}{c}\text { Balanço } \\
{[\mathbf{B}]}\end{array}$ \\
\hline Rio Grande do Sul & 6.293 & 7.191 & -898 \\
Paraná & 4.817 & 9.355 & -4538 \\
Mato Grosso & 4.198 & 1.734 & 2464 \\
Mato Grosso do Sul & 2.229 & 2.239 & -10 \\
Goiás & 1.968 & 1.485 & 483 \\
São Paulo & 1.156 & 3.817 & -2661 \\
\hline TOTAL & 20.661 & 25.821 & \\
\hline
\end{tabular}

Fontes: a - FNP Consultoria (1996) b - Estrazulas (1996)

Os portos de exportação e as respectivas porcentagens de soja e farelo de soja exportados por cada um deles podem ser visualizados na Tabela 2.3. Nota-se que o porto de Santos apresenta boa participação nas exportações de soja em grão, tendo, no entanto, uma participação bastante discreta para o farelo de soja. 
Tabela 2.3 - Principais portos brasileiros de exportação e as respectivas quantidades e porcentagens exportadas de soja em grão e farelo de soja no ano de 1992.

\begin{tabular}{lrrrr}
\hline \multicolumn{1}{c}{ Porto } & \multicolumn{2}{c}{ Soja em grão } & \multicolumn{2}{c}{ Farelo de soja } \\
& $\mathbf{1 . 0 0 0 \mathbf { t }}$ & $\mathbf{( \% )}$ & $\mathbf{1 . 0 0 0 ~}$ & $\mathbf{( \% )}$ \\
\hline Rio Grande - RS & 1.331 & 31,1 & 2.331 & 26,6 \\
Paranaguá - PR & 1.413 & 33,0 & 4.984 & 56,8 \\
Santos - SP & 1.199 & 28,0 & 178 & 2,0 \\
São Francisco - SC & 55 & 1,3 & 1.010 & 11,5 \\
Vitória - ES & 218 & 5,0 & 136 & 1,6 \\
Outros & 68 & 1,6 & 131 & 1,5 \\
\hline TOTAL & 4.284 & & 8.770 & \\
\hline
\end{tabular}

Fonte: Estrazulas (1996)

O transporte é um elemento de extrema importância para o complexo soja, em especial para as produções destinadas à exportação. Licio \& Carbucci (1996) destacam que o transporte predominantemente rodoviário. que interliga as zonas produtoras da região da Chapada dos Parecis-MT aos portos de Santos-SP e Paranaguá-PR, representa de $35 \%$ a $40 \%$ do preço final do produto, posto nos referidos portos. Ferreira et al. (1993) destacam as diferenças do peso do transporte entre as regiões produtoras, salientando que para as regiões do Sul e Sudeste o transporte representa pouco mais de $10 \%$ da cotação da soja ou farelo no porto. Já para a região Centro-Oeste, tal valor atinge mais de $30 \%$.

\subsection{Características da atividade de transporte}

Da região produtora ao consumidor. o produto agrícola utiliza uma série de serviços que the agregam valor. A transferência espacial é um dos serviços necessários para que o produto agrícola chegue até o consumidor final. De acordo com Barros (1987), a transferência espacial de produtos agrícolas envolve mais do que seu transporte, incluindo: coleta do produto. reunião em terminais de carga, transporte para os centros consumidores e distribuição para atacadistas e varejistas. $O$ custo de transferência é formado pelo custo de transporte. diretamente relacionado com a 
distância. e pelo custo terminal. que é independente da distância. O entendimento da influência desses custos sobre o preço final do produto. bem como sobre a renda do produtor. é fundamental na avaliação da importância que o transporte tem sobre o processo agrícola como um todo.

Destacando a importância do transporte para a agricultura, Gallimore (1981) afirma que tão importante quanto a habilidade na produção deve ser a habilidade de transportá-la até os centros consumidores. 2 Essa habilidade depende do sistema de transporte existente, da quantidade e localização das terras produtivas e da adequação dos serviços de transporte.

Koo \& Larson (1985) destacam a importância da eficiência do sistema de transporte sobre os produtores e consumidores, além da sua vital função de ligação entre a produção e o mercado agrícola de produtos e insumos. Os autores associam a prosperidade da agricultura ao sistema de transporte que viabiliza a distribuição de produtos e insumos, ao menor custo possível.] A competitividade externa dos produtos agrícolas também relaciona-se com os custos de transferência desses produtos até os países consumidores. Dessa forma, produtores rurais, consumidores domésticos e consumidores externos podem todos se beneficiar de um sistema de transporte eficiente.

Kyle (1980) destaca que a redução dos custos de transferência da produção pode representar função substancial na batalha contra a inflação. Algum aumento no custo de transferência de produtos volumosos (grãos, fertilizantes, carvão, ferro, entre outros), produz um efeito multiplicador sobre o produto da economia. $O$ autor salienta que $o$ custo de transferência é mais significativo nos custos finais de matérias-primas e produtos volumosos, que para os produtos finais.

Estudando as interrelações entre o mercado de grãos e o de transporte dos EUA, Fedeler \& Heady (1976) afirmam que variações no custo de transporte produzem modificações substanciais na quantidade e direção do fluxo individual interregional de grãos. mas somente pequenas modificações na localização da produção. Modificações nos custos têm impacto maior nos preços e no retorno ao investimento que na localização da produção, sendo o efeito sobre preços e retorno não uniforme entre as 
regiões. Destacam ainda que as relações entre as indústrias de grãos e transporte devem ser mais exploradas e que ambas indústrias pressupõem investimentos de longo prazo e que, dada a interdependência entre elas, investimentos de uma indústria podem se tornar não lucrativos com a ocorrência de modificações na outra.

Enfocando o transporte de grãos, o Council for Agricultural Science and Technology (1974) destaca os problemas comuns a todas as modalidades de transporte nos EUA:

- indisponibilidade de capital necessário para expansão, ocasionado pela inadequada remuneração ;

- inadequada coordenação entre ferrovia, rodovia e hidrovia, o que resulta em duplicação de trabalho e outras ineficiências;

- insuficiente comunicação entre transportador. embarcador e receptor. para desenvolver as necessárias melhorias, o planejamento e uma utilização eficiente de equipamentos.

São destacadas como alternativas para a solução dos problemas citados: a parcial ou total desrregulamentação do transporte, de forma a permitir taxas de retorno de capital determinadas pelo mercado; o desenvolvimento de mecanismos de empréstimos governamentais subsidiados; e o desenvolvimento de um sistema de informação que poderia oferecer, para todas as modalidades de transporte, bases para melhor coordenação, maior eficiência de utilização de equipamentos e melhoria dos serviços.

\subsection{Estrutura da matriz de transporte}

O conhecimento das particularidades de cada modalidade de transporte é essencial para a sua exploração eficaz. Min (1991) apresenta dados sobre as características de cada modalidade de transporte. conforme reproduzido na Tabela 2.4. Observa-se que não existe um tipo de transporte dominante, com vantagens em todos os itens. 
Tabela 2.4 - Comparação geral das modalidades de transporte nos EUA.

\begin{tabular}{|c|c|c|c|c|}
\hline \multirow[t]{2}{*}{ Característica } & \multicolumn{4}{|c|}{ Tipo de transporte } \\
\hline & Rodoviário & Ferroviário & Aéreo & Hidroviário \\
\hline Custo & moderado & baixo & alto & baixo \\
\hline Tipo de percurso & ponto-a-ponto & $\begin{array}{l}\text { terminal-a- } \\
\text { terminal }\end{array}$ & $\begin{array}{l}\text { terminal-a- } \\
\text { terminal }\end{array}$ & $\begin{array}{l}\text { terminal-a- } \\
\text { terminal }\end{array}$ \\
\hline Percurso médio $(\mathrm{km})$ & 828 & 992 & 1424 & $605-2.200$ \\
\hline Capacidade $(\mathrm{t})$ & $9-23$ & $45-11.000$ & $4,5-113$ & $900-54.500$ \\
\hline Velocidade & moderada & lenta & rápida & lenta \\
\hline Disponibilidade & alta & moderada & moderada & baixa \\
\hline $\begin{array}{l}\text { Variabilidade do } \\
\text { tempo em trânsito }\end{array}$ & alta & moderada & alta & baixa \\
\hline Perdas & baixa & moderada-alta & baixa & $\begin{array}{l}\text { baixa- } \\
\text { moderada }\end{array}$ \\
\hline
\end{tabular}

Fonte: $\operatorname{Min}(1991)$

As modalidades de transporte ferroviário, hidroviário e aéreo fazem a movimentação de cargas de terminal a terminal, ou seja, elas necessitam associar-se com o transporte rodoviário para atingir o ponto de produção e/ou entrega.

Surge então a necessidade de, na maioria dos casos, operar com mais de um modo de transporte. Min (1991) define multimodalidade ${ }^{6}$ como a movimentação de cargas da origem ao destino, usando um conjunto de vários modos de transporte. Segundo o mesmo autor, a multimodalidade oferece a oportunidade de grande redução dos custos e melhoria dos serviços, mas pode criar muitas outras dificuldades, dada a variedade de opções complexas.

A multimodalidade, como alternativa da melhoria da produtividade do trabalho, é destacada por Kyle (1980). O autor ressalta que a combinação das melhores características dos transportes ferroviário e hidroviário pode oferecer melhoria significativa na produtividade do processo de distribuição.

${ }^{6}$ Muitos autores adotam a palavra intermodalidade para se referir ao uso de várias modalidades em uma atividade de transporte. No presente trabalho será adotado o termo multimodalidade para esse fim. 
Caixeta (1995), avaliando as modalidades de transporte. destaca que os modos ferroviário e hidroviário requerem menores taxas de energia por $\mathrm{t} / \mathrm{km}$ e menores custos de manutenção. No entanto, também destaca a necessidade de conjugação com o transporte rodoviário, o que diminui a competitividade da ferrovia e hidrovia, em jornadas de curta e média distâncias.

Para o caso específico dos EUA, a divisão modal do transporte, de acordo com o U.S. Bureau of Census (CFS-Commodities Flow Survey), pode ser vista na Tabela 2.5.

Tabela 2.5 - Carga transportada por modalidade nos EUA, 1993.

\begin{tabular}{|c|c|c|c|}
\hline Modalidade de transporte & $\begin{array}{c}\text { Valor } \\
\text { (USS milhões) }\end{array}$ & $\begin{array}{c}\mathrm{t} \\
(\mathrm{mil})\end{array}$ & $\begin{array}{c}\text { t.km } \\
\text { (milhões) }\end{array}$ \\
\hline Todos os Modos & 6.037 .220 & 8.949 .855 & 1.418 .880 \\
\hline \multicolumn{4}{|c|}{ Unimodal } \\
\hline Caminhões proprios & 1.789 .798 & 3.225 .976 & 133.944 \\
\hline Caminhões alugados & 2.775 .836 & 2.650 .282 & 357.722 \\
\hline Aéreo & 41.520 & 439 & 346 \\
\hline Ferroviário & 250.534 & 1.424 .359 & 540.394 \\
\hline Fluvial & 41.645 & 332.217 & 92.736 \\
\hline Grandes Lagos & 624 & 31.150 & 6930 \\
\hline Maritimo & (S) & $(\mathrm{S})$ & $(\mathrm{S})$ \\
\hline Dutoviário (1) & 84.053 & 423.272 & (S) \\
\hline \multicolumn{4}{|c|}{ Multimodais } \\
\hline Caminhões próprios e alugados & 22.567 & 29.409 & 2.623 \\
\hline Caminhões e aéreo & 107.736 & 2.083 & 1.591 \\
\hline Caminhões e ferroviário & 82.895 & 34.486 & 24.311 \\
\hline Caminhões e fluvial & 8.232 & 65.364 & 27.202 \\
\hline Caminhões e dutoviario (1) & 649 & 3.072 & (S) \\
\hline Ferrovia e fluvial & 3.260 & 60.546 & 31.409 \\
\hline Fluvial e Grandes Lagos & (S) & $(\mathrm{S})$ & (S) \\
\hline Fluvial e Marítimo & 16.514 & 72.613 & 71.244 \\
\hline \multicolumn{4}{|c|}{ Outros } \\
\hline Modos diversos & 246.056 & 566.851 & 74.202 \\
\hline
\end{tabular}

${ }^{7}$ Dados obtidos na Internet, pelo endereço: FTP FTP.CENSUS.GOV/PUB/ECONOMY/93cflocv.txt 
Pelos dados da Tabela 2.5. pode-se fazer comparações quanto ao volume e valor transportado por cada modalidade. Por exemplo. o valor total das cargas transportadas por via aérea simples é aproximadamente igual ao do transporte fluvial simples. mas com uma quantidade em torno de 700 vezes menor. Ao mesmo tempo, pode-se observar. para o transporte multimodal, que o transporte hidroviário conjugado com outro modo se destaca em relação às demais combinações quanto ao volume, reforçando a sua necessidade de coordenação com as outras modalidades.

$\mathrm{Na}$ Tabela 2.6 tem-se um maior detalhamento da variável "momento de transporte" ponderação da quantidade transportada pela distância em t.km, para o caso dos EUA.

Tabela 2.6 - Composição do momento de transporte para os EUA, 1993.

\begin{tabular}{lrrr}
\hline $\begin{array}{c}\text { Modalidade de } \\
\text { transporte }\end{array}$ & $\begin{array}{c}\text { t.km } \\
\text { (milhões) }\end{array}$ & $\begin{array}{c}\text { t.km } \\
\mathbf{( \% )}\end{array}$ & $\begin{array}{c}\text { Média de } \\
\text { percurso } \\
\text { (km) }\end{array}$ \\
\hline Caminhões & 502.437 & 35,4 & 224 \\
Aéreo & 1.851 & 0,1 & 2.070 \\
Ferroviário & 569.614 & 40,1 & 1.629 \\
Fluvial & 143.664 & 10,1 & 555 \\
Grandes Lagos & 24.966 & 1.8 & 985 \\
Marítimo & 63.762 & 4,5 & 3.748 \\
Dutoviário & $(\mathrm{S})$ & $(\mathrm{S})$ & $(\mathrm{S})$ \\
Outros modos & 80.425 & 5,7 & 749 \\
\hline Total & 1.418 .880 & 100.0 & 649 \\
\hline
\end{tabular}

Fonte: U.S. Bureau of Census, 1993 Commodity Flow Survey

(1) os dados se referem tanto à modalidade simples quanto à conjugada com outras modalidades.

(S) os dados apresentaram alta variabilidade e não foram considerados.

Pelos dados da Tabela 2.6, nota-se que a maior parte do momento de transporte é representada por ferrovias (40\%); em segundo lugar, está o transporte rodoviário por caminhões $(35,4 \%)$ e em terceiro lugar o transporte fluvial (10\%). 
Ainda na Tabela 2.6. propriamente na coluna média de percurso. observa-se que os percursos maiores são próprios dos seguintes modos: transporte marítimo, 3.748 km; aéreo. $2.070 \mathrm{~km}$; ferroviário, $1.629 \mathrm{~km}$ e fluvial, $555 \mathrm{~km}$. O transporte rodoviário por caminhão atua em percursos menores $(224 \mathrm{~km})$.

A divisão modal para alguns países europeus, apresentada por Bonnot (1993), é reproduzida na Tabela 2.7. Nota-se que o papel do transporte hidroviário para os Países Baixos é essencial, sendo sua participação relativa nos demais países (a menos da França), também bastante relevante.

Tabela 2.7 - Divisão modal (\%), segundo o momento de transporte (t.km), para países europeus selecionados, ano de 1992.

\begin{tabular}{lrccc}
\hline Modo (\%) /País & França & Alemanha & Bélgica & Países Baixos \\
\hline Rodoviário & 65,2 & 52,4 & 67,2 & 34,1 \\
Ferroviário & 21,8 & 23,3 & 17,9 & 4.9 \\
Hidroviário (Fluvial) & 3,0 & 19,9 & 12,7 & 54,4 \\
Oleodutos & 10,0 & 4,4 & 2,2 & 6,6 \\
\hline
\end{tabular}

Fonte: Bonnot (1993)

Já para o caso brasileiro, de acordo com a Empresa Brasileira de Planejamento de Transporte - GEIPOT (1995), a divisão entre os modos de transporte (em t.km) para o ano de 1994 foi: $56,1 \%$ para o transporte rodoviário ${ }^{8}, 21,4 \%$ para o ferroviário, 0,29\% para o aéreo, 3,84\% para o dutoviário e $18,4 \%$ para o hidroviário fluvial (inclui navegação de interior e cabotagem). Em função da indisponibilidade de dados, fica difícil estimar a porcentagem da navegação de interior (ou fluvial) no transporte hidroviário. No entanto, trabalhando-se apenas com as quantidades transportadas, segundo os dados do GEIPOT (1995), a navegação de interior representa $12,57 \%$ do total transportado.

8 Os valores do transporte rodoviário e hidroviário são estimativas realizadas pelo GEIPOT. 


\subsection{0 transporte hidroviário}

Em muitos países, o transporte hidroviário é de suma importância na promoção do desenvolvimento regional e no oferecimento de uma alternativa de transporte bastante econômica. Conceitualmente, a palavra hidrovia refere-se ao transporte de cargas e pessoas por vias maritimas, fluviais e lacustres. Desta forma. sempre é importante verificar a abrangência dessa definição, ao se avaliar dados agregados.

No intuito de padronizar os conceitos e considerando que o presente trabalho se refere apenas ao transporte hidroviário por vias fluviais, será utilizada a palavra hidrovia com esse sentido.

O transporte hidroviário usualmente caracteriza-se pela movimentação de cargas volumosas de baixo valor agregado, a baixas velocidades. Grãos, farelos. fertilizantes, madeiras e combustíveis são cargas características do transporte hidroviário, de acordo com vários autores, como CESP (1992), Johnson \& Wood (1990) e Koo et al. (1985).

Comparando o transporte hidroviário com os demais modos, notam-se várias vantagens. Kraft et al. (1971) destacam que a grande vantagem do transporte hidroviário está na movimentação de grandes volumes por longas distâncias. Eastman (1982) salienta as vantagens comparativas do transporte hidroviário, segundo a produtividade do trabalho e do capital. em estudo realizado para os EUA no período de 1955 a 1979. A produtividade do trabalho na hidrovia $\left(\mathrm{t} . \mathrm{km} / \mathrm{n}^{\circ}\right.$. funcionários) foi $4-5$ vezes maior que na ferrovia e 10-15 vezes maior que na rodovia. Os investimentos hidroviários (t.km/US\$ investido) se mostraram quatro vezes mais produtivos que os rodoviários e duas vezes mais produtivos que os ferroviários. Quanto ao consumo de combustível, o autor verificou que a hidrovia transporta o dobro de t.km/l, em comparação com a ferrovia.

Segundo a CESP (1992), os custos do transporte hidroviário por vias fluviais de cargas no Brasil se situam entre US\$ 0,012 e US\$ 0,016 por t.km, o que representa algo em torno da metade dos valores observados para o transporte ferroviário, ou ainda três vezes mais barato que o rodoviário. 
Os valores apresentados evidencian uma grande vantagem do transporte hidroviário, em relação às outras modalidades disponiveis. Ressalte-se, no entanto. que conclusões a respeito dos valores devem ser feitas com ressalvas, dadas as diferenças de densidade de cargas e dos serviços oferecidos.

Outro aspecto interessante do transporte hidroviário é a sua menor agressão ao meio ambiente em comparação com as outras modalidades de transporte. Ellwanger (1995), analisando as externalidades da atividade de transporte, apresenta a modalidade rodoviária como responsável por $93 \%$ dos custos externos ${ }^{9}$, a aérea por $5,9 \%$, a ferroviária por $1.7 \%$ e a hidroviária por $0,3 \%$.

Por outro lado, o transporte hidroviário apresenta algumas limitações, como destacam Kraft et al. (1971). Segundo os autores, a hidrovia limita-se aos canais naturais fixos, sendo a construção de canais artificiais um procedimento de alto custo, justificável em poucos casos. Também destacam como limitação o fato do transporte hidroviário necessitar de complementação de outros modos, dado que a movimentação da carga é feita de terminal a terminal.

\subsubsection{Situação na Europa}

Em trabalho intitulado "Contemporary Problems of European Waterway", Bierman \& Rydzkowski (1988) realizaram o levantamento de toda a estrutura hidroviária européia, destacando as necessidades de investimento e melhoria. De acordo com os autores, a Europa tem liderado o desenvolvimento do transporte hidroviário. Grandes investimentos têm sido realizados no sentido de interligar os principais rios navegáveis via canais artificiais, de forma a se ter uma vasta rede hidroviária. As

${ }^{9}$ Custos gerados na produção ou consumo de bens e serviços, que não são diretamente pagos pelos consumidores ou produtores, mas por uma terceira parte, geralmente o poder público (Ellwanger, 1995). 
principais vantagens do sistema europeu são a densidade da rede hidroviária e seu alto grau de conectividade.

São dois os principais sistemas de navegação formados pelos rios Reno e Danúbio. O rio Reno possui navegabilidade em $1.291 \mathrm{~km}$. passando pela Suiça. França. Alemanha. Bélgica e Holanda, que representam a região mais industrializada da Europa. Além de ser uma grande artéria de transporte. o rio Reno realiza a interligação dos sistemas hidroviários de leste a oeste da Europa.

O rio Danúbio, por sua vez, possui $2.393 \mathrm{~km}$ navegáveis. No entanto, por atravessar uma região menos industrializada, o tráfego é inferior ao observado no rio Reno. Segundo a revista Navigation Ports \& Industries (1994), o transporte de cargas nos rios Danúbio e Reno foi de 28 e 290 milhões de toneladas, respectivamente.

Na Tabela 2.8 são apresentadas as quantidades transportadas exclusivamente por hidrovia e as distâncias médias percorridas. citadas por Bierman \& Rydzkowski (1988). Pode-se notar que, para os percursos apresentados, não há, basicamente, valores associados a longas distâncias.

Tabela 2.8 - Quantidades de mercadorias movimentadadas exclusivamente por transporte fluvial no ano de 1985. em alguns países da Europa.

\begin{tabular}{ccc}
\hline País & $\begin{array}{c}\text { Quantidade } \\
(\mathbf{1 0 0 0} \mathbf{)})\end{array}$ & $\begin{array}{c}\text { Distância média de } \\
\text { percurso (km) }\end{array}$ \\
\hline Austria & 6.912 & 203 \\
Bélgica & 84.950 & 52 \\
França & 62.498 & 228 \\
Alemanha Ocid. & 16.064 & 137 \\
Alemanha Orien. & 201.765 & 217 \\
Tchecoslováquia & 11.596 & 330 \\
Holanda & 231.786 & 128 \\
Polônia & 103.906 & 97 \\
Romênia & 15.615 & 148 \\
\hline
\end{tabular}

Fonte: Bierman \& Rydzkowski (1988)

Bierman \& Rydzkowski (1988) ainda destacam, no referido trabalho, a importância da modemização e ampliação dos sistemas de eclusas e canais, de forma a 
garantir a competitividade do transporte hidroviário, uma vez que, desde 1980. tem sido observado declínio deste tipo de transporte em todos os países das bacias do Reno e Danúbio. Uma das justificativas apresentadas pelos autores. para defender os investimentos no setor, refere-se ao volume de tráfego já existente e à necessidade de economia de energia. Também são estudadas para o transporte hidroviário europeu alternativas no sentido de economia de energia, como o uso do carvão, além de novas formas de composição de embarcações (comboios com 6 barcaças ao invés de 4), que podem representar diminuição de custo da ordem de $17 \%$ em relação ao comboio antigo. Outro aspecto destacado refere-se à eliminação de práticas discriminatórias e restrições legais, como forma de diminuição de custos e aumento da competitividade.

Concluindo, Bierman \& Rydzkowski (1988) questionam o transporte exclusivamente de cargas volumosas por hidrovia, sugerindo a ampliação do escopo das mercadorias como forma de adaptação às novas necessidades do mercado europeu.

\subsubsection{Situação nos EUA}

O sistema fluvial dos Estados Unidos, de acordo com Johnson \& Wood (1990), possui $25.749 \mathrm{~km}$ de extensão ${ }^{10} \mathrm{com} 2,7 \mathrm{~m}$ de profundidade mínima. Segundo o Bureau of Transportation Statistics - BTS (1994), o sistema hidroviário apresenta uma alta conectividade, sendo 86\% da extensão interligada. Da extensão total, o BTS (1994) destaca que $17.177 \mathrm{~km}$, que incluem 168 pontos de eclusagem com 211 câmaras ${ }^{11}$, são intensivamente utilizados de forma comercial.

O rio Mississippi consiste no principal eixo hidroviário comercial, sendo dividido em dois sub-sistemas, o Alto e o Baixo Mississippi. O primeiro conecta as principais cidades metropolitanas do Meio-Oeste, passando por cinco Estados, com $1.078 \mathrm{~km}$

\footnotetext{
${ }^{10}$ Descontando-se as rotas costais maritimas, os Grandes Lagos e o Sistema St. Lawrence Seaway.

11 Em um mesmo ponto de eclusagem, pode ocorrer mais de uma câmara, que corresponde ao local onde a embarcação efetivamente transpõe uma barragem.
} 
navegáveis. Quando o rio Mississippi se encontra com o rio Ohio, inicia-se o trecho denominado Baixo Mississippi. que vai até o Golfo do México. A conexão do Alto Mississippi com os Grandes Lagos é feita pelo rio lllinois. que possui extensão de 560 $\mathrm{km}$ navegáveis.

$\mathrm{Na}$ Tabela 2.9, pode ser observado o volume de carga norte-americana transportada por hidrovia durante o ano de 1993. Os ríos Mississippi e Ohio têm os maiores valores de transporte de carga, seguidos pelos rios Tennessee, Illinois, Monongahela, Kanawha e Columbia.

Tabela 2.9 - Quantidade transportada por hidrovias norte-americanas no ano de 1993.

\begin{tabular}{lc}
\hline Hidrovia & $\begin{array}{c}\text { Quantidade } \\
\text { (milhóes t) }\end{array}$ \\
\hline Alabama-Coosa & 1,09 \\
Allegheny & 2,81 \\
Apalachicola & 0,54 \\
Black Warrior & 21,50 \\
Columbia & 16,33 \\
Cumberland & 12,97 \\
Illinois & 41,37 \\
Kanawha & 20,23 \\
McClellan-Kerr & 8,53 \\
Mississippi & 270,61 \\
Missouri & 5,08 \\
Monongahela & 30,03 \\
Ohio & 206,11 \\
Snake & 4,81 \\
Tennessee & 43,73 \\
Tennessee Tombigbee & 6,44 \\
\hline TOTAL & 692,18 \\
\hline Fonte: Warerborne Commerce Statistics Center &
\end{tabular}

Johnson \& Wood (1990) destacam que o transporte hidroviário norte-americano especializou-se em produtos volumosos de baixo preço que não necessitam de rapidez de transporte. Citam como exemplos: o petróleo e seus subprodutos, que representam $36 \%$

12 Dados obtidos no serviço "Navigation Data Center". mantido pelo "U.S. Army Corp of Engineers" na Internet. endereço: http://www.wrc-nrc.usage.army.mil/ndc. 
do total transportado; carvão com $28 \%$ : e outros produtos. como grăos. subprodutos de grăos. produtos químicos, ferro, produtos florestais, cimento, sulfato, fertilizante. papel, areia. pedregulho e calcário. Esses produtos, segundo o BTS (1994), eram transportados em 1992 por 360 empresas, que operavam com embarcações de potência entre 1000 e $9000 \mathrm{hp}$. compostas de até 15 barcaças de $1360 \mathrm{t}$.

Os problemas enfrentados pela atividade de transporte hidroviário, relacionam-se basicamente, com o esgotamento da capacidade de eclusagem de muitos rios. Esse fato é ressaltado por Johnson \& Wood (1990) como o principal aspecto limitador da ampliação da utilização do sistema hidroviário.

\subsubsection{Situação no Brasil}

Várias bacias hidrográficas brasileiras possuem rios navegáveis, naturalmente ou por consequência de obras específicas. Segundo o RP Engenheiros Associados (1993), a partir de levantamento das bacias hidrográficas brasileiras e os respectivos rios navegáveis, é a Bacia Amazônica a maior rede hidroviária do Brasil, sendo seus principais rios navegáveis o Amazonas, Madeira, Negro, Branco, Xingú, Tapajós, Trombetas e Jari, onde foram movimentadas 3 milhões de toneladas no ano de 1990. Dentre os vários corredores de transporte, delineados pelo atual Governo Federal para a melhoria do sistema de transporte nacional, está o corredor noroeste, que prevê a utilização dos rios Madeira e Amazonas para o escoamento da produção agrícola da Chapada dos Parecis, localizada nos Estados de Rondônia e Mato Grosso (Licio \& Corbucci, 1996).

Os rios Araguaia e Tocantins formam a bacia que abrange parte das regiões Norte e Centro-Oeste. O rio Araguaia possui trechos navegáveis para embarcações de 1 a $1,2 \mathrm{~m}$ de calado e o Tocantins possui em quase toda sua extensão $2,5 \mathrm{~m}$ de profundidade

mínima. Para que todo o sistema fique navegável, é necessária a conclusão da eclusa da Barragem de Tucuruí. Essa alternativa de escoamento de grãos produzidos no Centro- 
Oeste do pais. sul e sudoeste do Maranhão e oeste da Bahia até a foz do rio Amazonas, está sendo chamada pelo Governo Federal de Corredor Centro-Norte.

A Bacia do rio São Francisco apresenta dois trechos navegáveis: o baixo São Francisco, com $208 \mathrm{~km}$, e o médio São Francisco. com $1.317 \mathrm{~km}$. São transportados no médio São Francisco gipsita, soja, carvão e arroz, resultados da comercialização do Centro-Oeste para o nordeste, em viagens que levam de 24 a 30 dias, dependendo da estação do ano. Licio \& Corbucci (1996) destacam que o Corredor de Transporte Nordeste, do qual o rio São Francisco faz parte. possibilitará a colocação competitiva, no Nordeste, do milho produzido no Centro-Oeste. com relação ao importado.

O rio Paraguai é outro importante meio de ligação do Centro-Oeste, formando com o rio Paraná um corredor de saída para o Oceano Atlântico. No trecho de Cáceres a Corumbá, a navegação pode ser feita por comboios de 2.500 t, e de Corumbá aos portos argentinos e uruguaios, por comboio de 7.500 a 15.000 t. De acordo com Chain Jr. (1995), o total de cargas transportadas em 1992 foi de 250.121 t, sendo $37.273 \mathrm{t}(15 \%)$ de soja, $1.389 \mathrm{t}$ de madeira e 2.313 cabeças de gado. No entanto. existem limitações ecológicas da navegação no rio Paraguai, pois determinadas obras requeridas pelos seus usuários poderiam ter efeito catastrófico sobre o ecossistema do Pantanal Matogrossense.

Na Bacia do Paraná localiza-se a hidrovia Tiete-Paraná, situada na região mais industrializada e economicamente ativa do país. No rio Tietê, que representa o chamado Tramo Tietê da hidrovia Tietê-Paraná. a navegabilidade é possivel desde sua foz até a foz do rio Piracicaba, seu afluente. No rio Paraná, a navegação estende-se entre São Simão (GO) e a hidrelétrica de Jupiá e desta até a hidrelétrica de Itaipu, representando esses dois trechos o Tramo Norte e o Tramo Sul da hidrovia Tietê-Paraná.

Nos rios do Sul, especialmente no Estado do rio Grande do Sul se desenvolve uma navegação economicamente intensa em cerca de $600 \mathrm{~km}$. Segundo os dados do GEIPOT (1995), nos portos hidroviários do rio Grande do Sul, foram movimentadas 5,7 milhões de t de granéis sólidos em 1994. 
Conforme foi apresentado, existem várias alternativas de transporte hidroviário no Brasil. No entanto, a sua utilização ainda encontra-se pouco desenvolvida. com raras exceções. Um aspecto importante a ser observado é a condição de navegação dos canais navegáveis, inclusive em termos de profundidade mínima. Na Tabela 2.10, é apresentada a distância navegável para os rios ou bacias que apresentem profundidade mínima acima de $2.5 \mathrm{~m}^{13}$. Como pode ser notado. a Bacia Amazônica é a que apresenta as maiores distâncias navegáveis com profundidade acima de $2,5 \mathrm{~m}$. As demais bacias e rios, apresentam valores bem menores. Nota-se, o posicionamento geográfico da Bacia Amazônica, com relação à produção agrícola. está associado a um pequeno potencial de movimentação de cargas agrícolas.

Tabela 2.10 - Distâncias navegáveis com profundidade mínima de $2,5 \mathrm{~m}$, para rios e bacias do Brasil, segundo levantamento de 1995.

\begin{tabular}{lcr}
\hline \multicolumn{1}{c}{ Bacia ou rio } & Distância $(\mathbf{k m})$ & $\mathbf{~ \% ~}$ \\
\hline Bacia do Amazonas & 5.583 & 65,7 \\
Bacia do Tocantins & 250 & 2,9 \\
Bacia do São Francisco & 208 & 2,4 \\
Bacia do Paraná & 710 & 8,4 \\
Bacia do Paraguai & 0 & 0 \\
Rios do Nordeste & 611 & 7,2 \\
Rios do Sudeste & 164 & 1,9 \\
Rios do Sul & 974 & 11,5 \\
\hline TOTAL & $\mathbf{8 . 5 0 0}$ \\
\hline Fonte: GEIPOT (1995)
\end{tabular}

$13 \mathrm{O}$ valor de $2.5 \mathrm{~m}$ fó adotado, considerando a referência de profundidade minima utilizada nos EUA, que possibilita a utilização mais intensiva do sistema hidroviário através de embarcações maiores. 


\subsubsection{Hidrovia Tietê-Paraná}

Na Bacia do Paraná localiza-se a hidrovia Tietê-Paraná composta pelos rios Tietê, Paraná e alguns de seus afluentes.

Até o presente, a navegação está sendo realizada em dois trechos separados. O primeiro inicia-se em São Simão (GO) e vai até Santa Maria da Serra (SP), no rio Piracicaba e Anhembi (SP), no rio Tietê, esse trecho corresponde aos Tramo Norte e Tietê da hidrovia. O segundo trecho estende-se da barragem de Itaipu até a barragem de Jupiá, ambas no rio Paraná, sendo chamdo de Tramo Sul da hidrovia. Para que os dois trechos sejam conectados, é necessário o término da eclusa de Jupiá.

Uma característica específica dessa hidrovia é a não conexão com o mar. Para que isso ocorra sem interrupções à navegação, é necessária a construção de um sistema de eclusas na barragem de Itaipu, obra considerada bastante dispendiosa. Na Figura 2.3 podem ser vistas as principais características da hidrovia Tietê-Paraná.

Outro aspecto importante relaciona-se com a disponibilidade de outras modalidades de transporte na região da hidrovia Tietê-Paraná. A ferrovia tem um traçado bastante paralelo ao da hidrovia, representado pela SR-10 da RFFSA (Rede Ferroviária Federal S.A.), que liga Corumbá a Bauru; e pelos trechos da FEPASA (Ferrovia Paulista S.A.) entre Santa Fé do Sul e Araraquara, Panorama e Bauru e Presidente Epitácio e Botucatu. A rodovia também apresenta disposição paralela, representada pelas estradas estaduais de São Paulo, a SP-320, a SP-310, a SP-300, SP294 e a SP-270. Esses detalhes podem ser vistos nas Figuras 2.4 e 2.5.

Quanto à estrutura de navegação, o primeiro trecho apresenta 5 barragens, totalizando 6 eclusas, com distâncias entre as mesmas variando de 50 a $100 \mathrm{~km}$, de 
acordo com a CESP (1995a). Todas as eclusas desse trecho possuem dimensões iguais, com $142 \mathrm{~m}$ de comprimento e $12 \mathrm{~m}$ de largura.

Com base nas eclusas e na profundidade mínima do canal de navegação, a CESP estabeleceu o comboio padrão de transporte de carga, que para o primeiro trecho é denominado "Comboio Tietê", e deve ter dimensões máximas de 2,5 m de calado, 137 $\mathrm{m}$ de comprimento e $11 \mathrm{~m}$ de largura.

Para o segundo trecho, como as eclusas são de $210 \mathrm{~m}$ de comprimento e $17 \mathrm{~m}$ de largura, o comboio padrão, denominado "Comboio Paraná", deve ter no máximo $3,5 \mathrm{~m}$ de calado, $141 \mathrm{~m}$ de comprimento e $10 \mathrm{~m}$ de largura.

Em função das dimensões, o Comboio Tietê pode transportar até $2.200 \mathrm{t}$ e o Comboio Paraná até 6.600 t, exigindo para isso, respectivamente, entre 900 e $1300 \mathrm{hp} \mathrm{e}$ entre 1.800 e $2.200 \mathrm{hp}$ de potência do empurrador, segundo a CESP (1995a). Na Figura 2.6, pode-se visualizar o esquema do comboio Tietê.

Os terminais de embarque e desembarque da hidrovia Tietê-Paraná são, em sua maioria, de propriedade das empresas transportadoras. Os principais terminais são o de São Simão, Pederneiras, Araçatuba, Santa Maria da Serra e Anhembi.

O órgão gestor das operações de eclusagem e manutenção dos canais da hidrovia Tietê-Paraná é a CESP. A fiscalização, o licenciamento e controle do tráfego é realizado pela Capitania Fluvial da hidrovia Tietê-Paraná, divisão da Marinha Brasileira. 


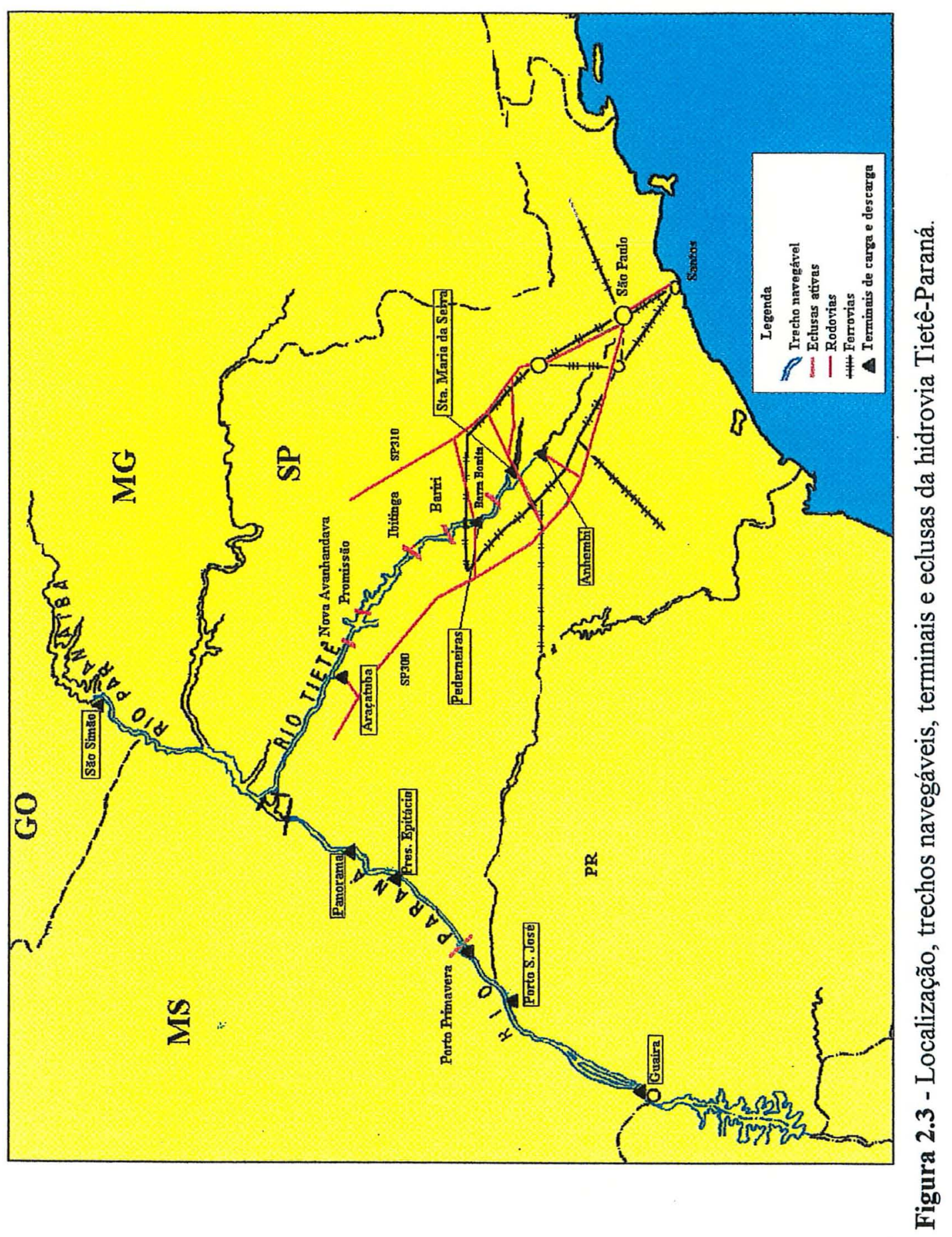




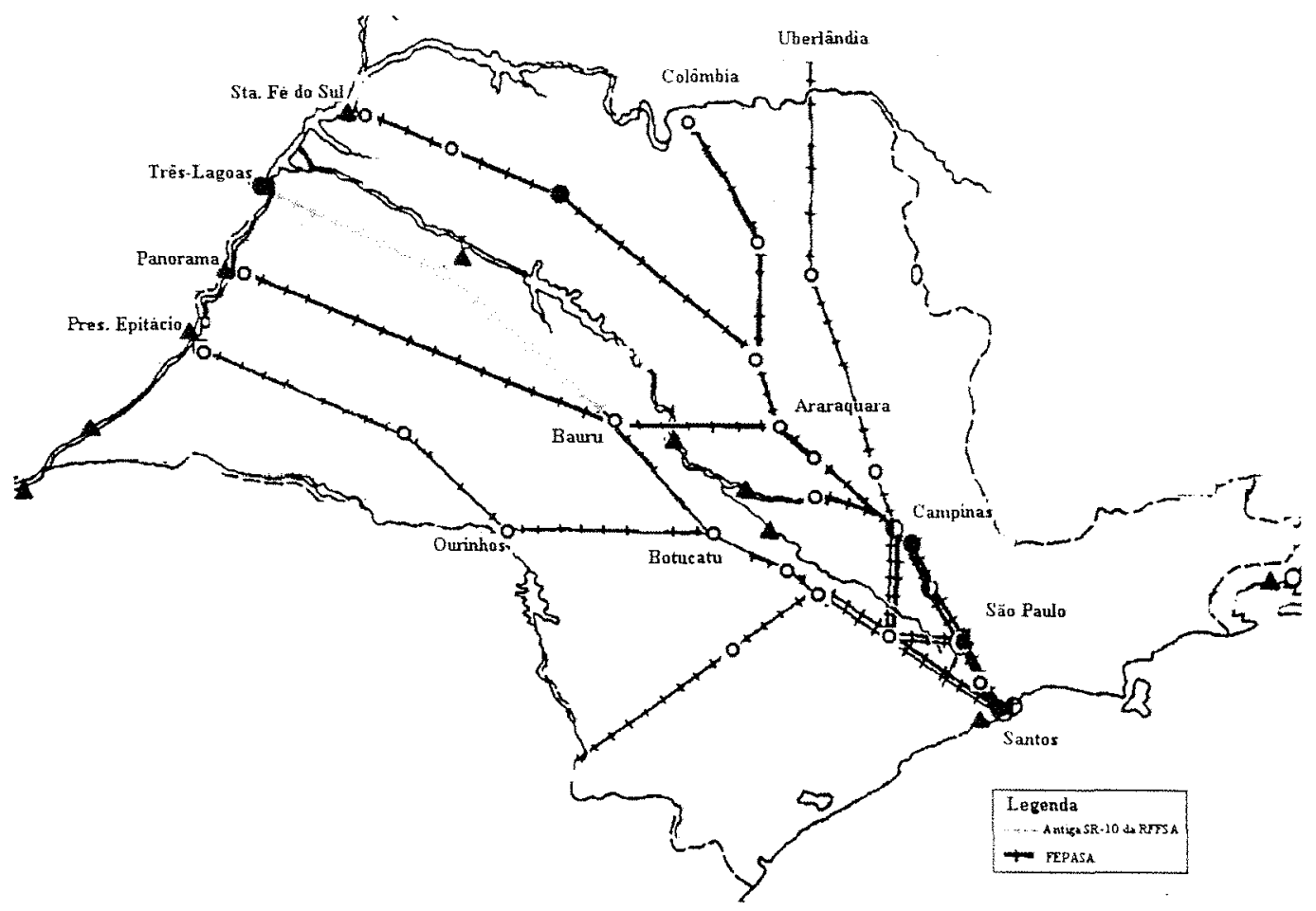

Figura 2.4 - Esquema do Estado de São Paulo, mostrando o paralelismo das estradas de ferro com relação à hidrovia Tietê-Paraná.

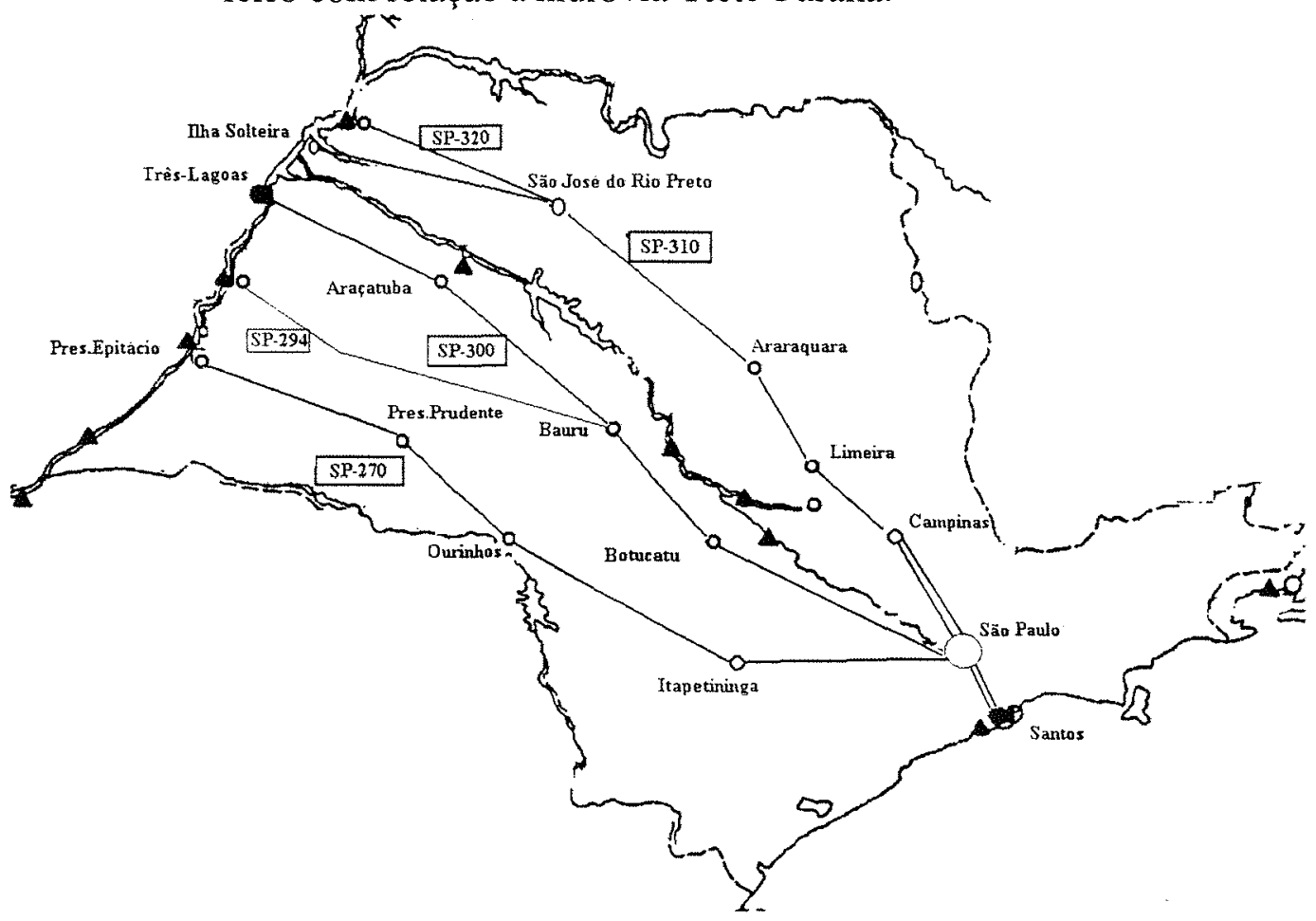

Figura 2.5 - Esquema do Estado de São Paulo, mostrando o paralelismo das rodovias estaduais com relação à hidrovia Tietê-Paraná. 

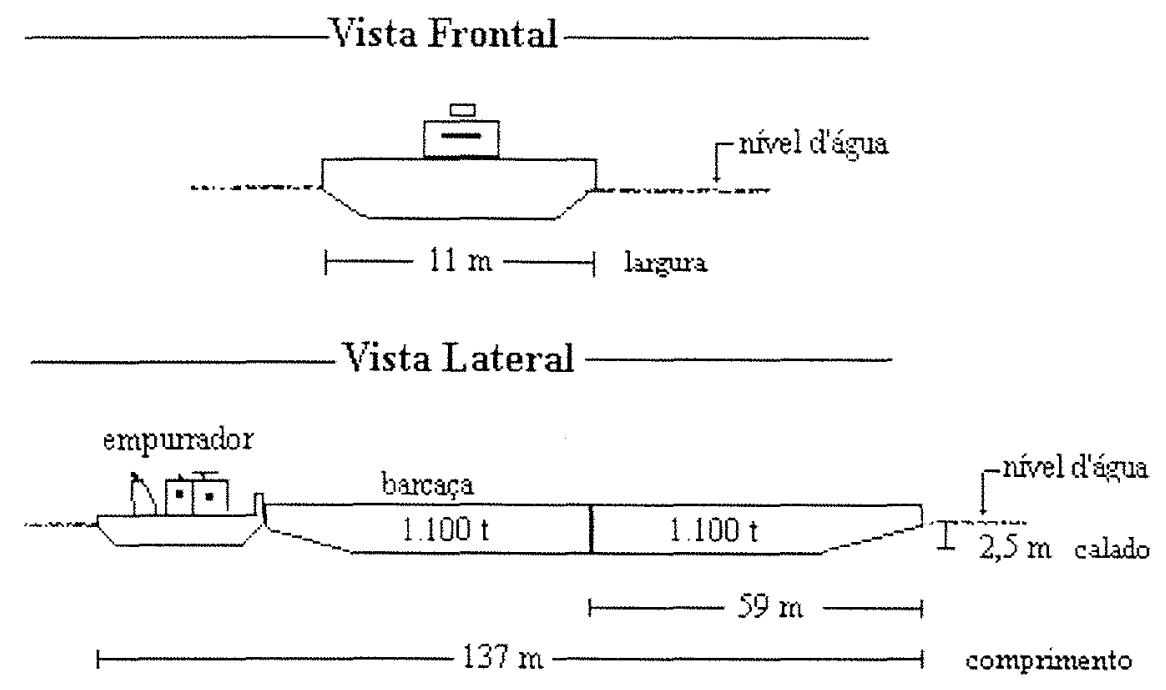

Figura 2.6 - Esquema do comboio Tietê-Paraná, elaborado com base nas especificações da CESP (1995a).

\subsection{Considerações Finais}

Conforme as informações apresentadas, o milho é um produto agrícola destinado ao abastecimento interno, em especial para o atendimento da demanda por alimentação animal. O Estado de São Paulo é o maior consumidor e importador de milho de outras regiões, principalmente dos Estados de Goiás e do Paraná. Os agentes envolvidos com a comercialização do milho são produtores, cerealistas, cooperativas, armazéns gerais, empresas de produção animal e indústrias (de ração, moagem seca e úmida). O transporte representa cerca de $20 \%$ do preço final do milho, para um percurso de $600 \mathrm{~km}$, sendo que, com o aumento da distância, essa porcentagem pode ser ainda maior.

A soja tem a maior parte de sua produção destinada ao mercado interno, fundamentalmente para o abastecimento da produção de óleo de soja. O farelo de soja, sub-produto da produção do óleo, destina-se à alimentação animal e é exportado em sua 
maior parte. Na comercialização da soja em grão destacam-se os produtores, as cooperativas. as indústrias e os exportadores. Já o farelo de soja é basicamente transacionado pelas próprias indústrias no mercado interno e externo. O Estado de São Paulo apresenta um déficit entre produção e consumo e o porto de Santos destaca-se na exportação de soja em grão e não na de farelo de soja. O transporte representa de $10 \% \mathrm{a}$ $40 \%$ do preço final do produto, de acordo com a distância da zona produtora aos portos e regiões consumidoras nacionais.

As características produtivas e de comercialização da soja e do milho serão importantes parâmetros para a análise proposta. Atenção especial foi dada ao Estado de São Paulo, em função da sua importância com relação à geração de movimentações dos produtos estudados, e da posição geográfica da hidrovia Tietê-Paraná.

Quanto às características da atividade de transporte. destacou-se que o custo de transferência inclui o custo de transporte e o custo terminal, sendo o primeiro dependente da distância de movimentação e o segundo dependente do tempo de operação. Salientou-se também que, dada a característica de investimento de longo prazo da atividade de transporte e da produção agrícola, as interrelações entre essas duas atividades devem ser muito bem ponderadas.

$\mathrm{Na}$ estrutura da matriz de transporte. pôde-se notar que cada modalidade de transporte apresenta vantagens e desvantagens. não existindo uma modalidade superior em todos os aspectos. As modalidades ferroviária e hidroviária pressupõem a associação com a modalidade rodoviária para atingir os pontos de destino. De acordo com dados dos EUA, a média de distância do transporte rodoviário é de $224 \mathrm{~km}$, ou seja, nesse país essa modalidade é basicamente utilizada na distribuição intrarregional.

O transporte hidroviário apresenta várias vantagens com relação às outras modalidades, principalmente quanto à produtividade dos recursos empregados. No entanto, limitações tais como os canais fixos de navegação, necessidade de integração com outras modalidades e velocidade lenta, não podem ser desprezados na avaliação do seu potencial. 
Os grandes exemplos mundiais de utilização do transporte hidroviário são a Europa e os EUA. Nesses dois casos observou-se que o sistema hidroviário é amplamente utilizado, apresentando volumes expressivos (até 250 milhões de $t$ por ano). Pode-se considerar que o volume de investimento, a distribuição geográfica e a interconectividade, foram elementos fundamentais que permitiram atingir tal nível de utilização. Nos EUA, os principais produtos transportados são o petróleo e o carvão, sendo os produtos agrícolas responsáveis por cerca de $12 \%$ do volume total transportado. Por outro lado, o Brasil apresenta um sistema hidroviário desconectado, que necessita de investimentos pesados para se tornar uma alternativa amplamente utilizável, ainda mais porque as regiões produtoras, especialmente de grãos não coincidem com as de maiores recursos hidroviários.

Não obstante, há tradição do transporte hidroviário europeu e norte-americano, existe preocupação com a competitividade desses sistemas, em especial com relação aos efeitos de práticas discriminatórias, de restrições legais e da capacidade estrutural (principalmente eclusas) sobre a economia das empresas transportadoras.

A hidrovia Tietê-Paraná apresenta algumas particularidades como paralelismo de ferrovias e rodovias, não ligação com o mar e com outros sistemas hidroviários. Por outro lado, encontra-se entre uma região tipicamente produtora de grãos e uma tipicamente consumidora.

No próximo capítulo serão destacados os aspectos teóricos norteadores da análise proposta para este estudo. 


\section{ARCABOUÇO TEÓRICO PARA A MODELAGEM DO TRANSPORTE}

O presente capítulo tem o objetivo de apresentar a teoria relacionada com o assunto em discussão, de forma a estabelecer bases para os procedimentos e definição dos padrões a partir dos quais os resultados serão discutidos.

No item 3.1, serão destacados os agentes envolvidos com a atividade de transporte e as suas interrelações.

No item 3.2, serão destacados os elementos importantes na análise do prestador do serviço de transporte, além das variáveis influenciadoras do seu comportamento e custos.

O comportamento e os custos do usuário dos serviços de transporte serão destacados no item 3.3 .

No item 3.4 serão abordados os vários aspectos relacionados com a atividade de transporte multimodal, assim com as vantagens e limitações desse serviço que devem ser consideradas na análise.

No item 3.5 será focada a demanda por transporte, através da análise dos volumes captados por uma determinada modalidade de transporte, considerando-se aspectos dessa demanda por transporte assim como das características do serviço ofertado.

\subsection{Agentes do ambiente de transporte}

Daskin (1985) destaca que os agentes envolvidos no processo de decisão na atividade de transporte são os produtores, transportadores, governo e consumidores. De 
acordo com o autor, os serviços de transporte, no setor privado, são avaliados em valores monetários e os objetivos são basicamente econômicos. de minimização de custos ou maximização de lucro, se as condições de mercado forem exógenas ou endógenas, respectivamente. Para o setor público, em particular. os serviços de transporte não podem ser avaliados apenas monetariamente, não bastando para o governo os objetivos de minimizar custo ou maximizar lucro.

Daskin (1985) destaca que embarcadores (setor privado) e agências de serviço (setor público) são os agentes econômicos que exercem a demanda por transporte, e assim o fazem para atender a demanda de consumidores e sociedade por bens e serviços. Kanafani (1983) ressalta que a demanda por transporte é derivada da interação entre atividades socioeconômicas dispersas no espaço. Por outro lado, transportadores privados e públicos ofertam o serviço de transporte. e são influenciados pela infraestrutura, financiamento, subsídios, regulamentação da atividade, fatores estes, em sua maioria, geridos pelo setor público.

Sendo assim, estudos aplicados ao transporte devem considerar o padrão de interrelação entre usuários e prestadores dos serviços de transporte, ambos influenciados pelas ações governamentais.

As decisões com que cada agente se defronta durante o exercício de sua atividade, são aspectos que também devem ser considerados. Daskin (1985) destaca que os usuários dos serviços de transporte frequentemente decidem no curto prazo sobre a gerência de estoques e a comercialização; no médio prazo decidem sobre a modalidade e o prestador do serviço; e no longo prazo decidem sobre a localização das instalações e sobre o planejamento da produção. Os prestadores do serviço, por sua vez, reagindo a uma demanda específica. decidem no curto prazo sobre a rota e a programação de transporte; no curto/médio prazo decidem sobre o nível de serviço, o tamanho e o tipo da frota; e no longo prazo decidem sobre a configuração da rede de transporte. Daskin (1985) destaca que o nível de serviço entre um par de origem e destino é definido pelo preço do frete. tempo de trânsito (média e variância). atrasos, perdas e danos. 
O Governo. por outro lado. deve decidir sobre a sua participaçăo na atividade de transporte quanto à manutenção e ampliação da infra-estrutura básica. à disponibilização de subsídios, à taxação e à natureza da regulamentação. considerando como restrição a velocidade das ações (curto, médio e longo prazo). Sobre os serviços prestados pelo setor público, o Governo deve decidir ainda sobre a prestação direta, por intermédio de suas próprias agências, ou por repasse ao setor privado.

Finalmente, além das interrelações e decisões dos agentes envolvidos na atividade de transporte, tem-se todo o ambiente econômico da região onde eles estejam inseridos. O nível de crescimento, a disponibilidade de capital para investimentos, a taxa de inflação, a competição com produtos internacionais, o nivel tecnológico e da mão-de-obra, são fatores macroeconômicos que afetam as interrelações e decisões dos agentes no curto, médio e longo prazo.

A seguir, são destacados os aspectos específicos do prestador e do usuário do serviço de transporte, detalhando-se as variáveis influenciadoras do comportamento econômico de cada um desses dois agentes.

\subsection{Prestador do serviço de transporte}

Bronzini et al. (1985) destacam a seguinte máxima referente à atividade de prestação do serviço de transporte hidroviário:

\section{“Quando o negócio vai bem não se pode ir rápido o suficiente e quando o negócio vai mal não se pode ir devagar o suficiente"}

As particularidades do transporte hidroviário definem um padrão de reação aos estímulos advindos do mercado, como pode-se perceber da frase apresentada anteriormente. Desta forma, o entendimento das variáveis influenciadoras da oferta fornece subsídios para a análise de cada modalidade e do seu potencial competitivo. 
Kanafani (1983) destaca como fatores influenciadores da oferta dos serviços de transporte os seguintes itens:

- tecnologia: os custos de prestação do serviço de transporte estão associados com a tecnologia utilizada e com a adequação desta às condições de mercado e de infra-estrutura;

- estratégias de operação: a maneira pela qual uma determinada tecnologia é utilizada depende do comportamento e dos objetivos do prestador do serviço, ou seja, da sua estratégia de operação em um determinado mercado;

- exigências e restrições institucionais: as estratégias de operação e a política de preços são frequentemente sujeitas às exigências e restrições impostas por regulamentações ou pela estrutura de mercado:

- comportamento do consumidor: a maneira pela qual os usuários utilizam os serviços de transporte (volume, frequência de cargas, época de demanda, entre outras) e a percepção dos custos incorridos ou percebidos como incorridos, determinam alguns aspectos da oferta dos serviços de transporte, como, por exemplo, a ociosidade do equipamento, a velocidade de transporte, o nível de proteção à carga.

No que se refere ao custo de produção dos serviços de transporte, aqui chamado de custo de transferência, pode-se dividi-lo em dois componentes básicos: o custo de transporte e o custo terminal. O primeiro, de acordo com Wright (1980) e Barros (1987), é função da distância percorrida e inclui o custo do capital (juros sobre o investimento e desgaste de material), combustível, lubrificantes, manutenção, depreciação proporcional à distância e mão-de-obra. O segundo. o custo terminal. corresponde às operações de preparo da carga para o transporte, cujos itens são variáveis com o tempo. Normalmente, os itens incluídos no custo terminal são: a mão-de-obra de carga e descarga; os juros sobre os investimentos em material rodante e equipamentos de terminal; a administração da operação: e as taxas de licenciamento e seguros. Do ponto 
de vista da distância. os custos de transporte e terminal são considerados variáveis e fixos, respectivamente.

A tecnologia utilizada em uma determinada modalidade de transporte (por exemplo, o tipo de veículo e o tipo de instalação). está diretamente relacionada com a proporção entre custos fixos e variáveis. Assim, a adequação da tecnologia às necessidades que o mercado solicita em seus diversos segmentos, é de extrema importância para a operação com custos adequados.

Um aspecto relacionado com a estratégia de operação é a intensidade de uso do equipamento e a sua influência sobre os custos, destacado por Michaels et al. (1982) e Beilock \& Casavant (1984). Beilock \& Casavant (1984) salientam duas dimensões da utilização do equipamento: a frequência de movimentação e a porcentagem de quilômetros percorridos com o veículo carregado.

A porcentagem de quilômetros percorridos com o veículo carregado está diretamente relacionada com a disponibilidade de cargas de retorno. Em determinadas modalidades, como na hidrovia, a diferença entre o custo de transporte para o veículo carregado e vazio é muito pequena. Sendo assim, a conjugação de cargas de retorno diminuiria o custo de transferência.

Beilock \& Casavant (1984) ainda destacam a relação entre a frequência de movimentação e a porcentagem de quilômetros com o veículo carregado, onde a diminuição no valor de uma variável implica no aumento do valor da outra para que não se alterem os custos.

Outro aspecto é a influência do volume transportado sobre os custos. Ao se calcular o custo fixo por unidade de volume ou de massa transportado, realiza-se uma estimativa da quantidade total a ser transportada durante um determinado período. Sendo assim, modificações na demanda por transporte tenderão a alterar os custos fixos unitários, de acordo com a estrutura de cada modalidade de transporte.

Michaels et al. (1982) destacam que o transporte rodoviário por caminhão possui capacidade de se ajustar às variações na demanda. Firmas individuais podem entrar ou 
sair da atividade em uma região, ajustando o seu investimento à demanda. Este aspecto torna o custo fixo, por unidade transportada por rodovia. razoavelmente estável com respeito ao volume de carga. Por outro lado, o mesmo não acontece com outras modalidades de transporte, como a ferroviária e hidroviária, cuja capacidade de ajustamento do investimento à demanda é muito lenta, resultando em variações do custo fixo por unidade transportada.

$\mathrm{Na}$ Figura 3.1, apresentada por Michaels et al. (1982), pode-se visualizar o impacto da alteração do volume transportado, sobre os custos unitários do transporte ferroviário e consequentemente sobre a sua competitividade na distância. As curvas v1. v2 e v3 representam o deslocamento da curva de custo unitário ocasionado pela diminuição do volume transportado pela modalidade ferroviária. Nota-se que com o deslocamento da curva de custo ferroviário de $\mathrm{v} 1$ para $\mathrm{v} 2$ e deste para $\mathrm{v} 3,0$ transporte rodoviário por caminhão passa a ser competitivo em una distância $d 2$ e posteriormente $d 3$ maiores que $d l$.

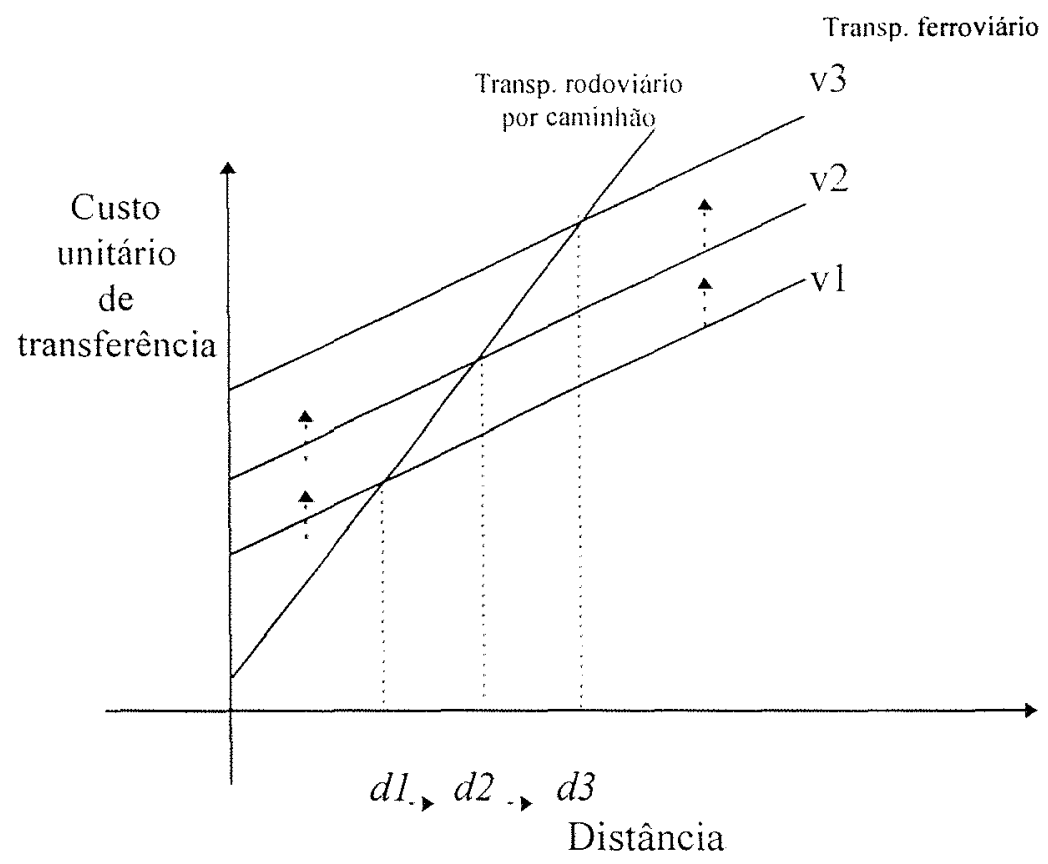

Figura 3.1 - Competição entre duas modalidades de transporte, dada a variação dos custos fixos (Fonte: Michaels et al., 1982). 
Os autores destacam que a densidade de produçĩo de uma região tem influência sobre a competição entre as modalidades de transporte. Regiões com produção esparsa tendem a favorecer o transporte rodoviário por caminhão, pois este se torna mais competitivo em distâncias maiores.

\subsection{Usuário do serviço de transporte}

A necessidade de transporte origina-se da interação entre atividades sociais e econômicas dispersas no espaço. Ao mesmo tempo. a complexidade e diversidade dessas atividades geram diferentes padrões de exigência quanto ao serviço de transporte (Kanafani, 1983). No caso das atividades que envolvem a comercialização de produtos agrícolas, a complexidade e diversidade advêm de particularidades do mercado desse produto e das suas características físicas. Como particularidades do mercado do produto, pode-se citar a sazonalidade da demanda e oferta, a variação de preços, a concentração do mercado e o destino do produto. Como características físicas do produto, podem ser citados: perecibilidade, o tempo de armazenamento e a resistência ao manuseio.

Com base nessas características mercadológicas e físicas específicas para um determinado produto ou conjunto de produtos, o usuário do serviço de transporte tomará as decisões em relação ao serviço de transporte que minimize o custo de movimentação pertinente. Miklius et al. (1976) destacam que produtos produzidos sazonalmente, na ausência de alterações imprevisíveis na demanda, favorecem serviços de transporte com maior tempo em trânsito. O autor também destaca que a variação do preço do produto favorece a escolha por serviços mais rápidos, se tal variação for significativa para um

curto periodo de tempo, e por serviços mais lentos, se aquela variação não for significativa. 
Kanafani (1983) classifica as decisões tomadas pelo usuário como estando relacionadas com a localização da produção e comercialização, com a natureza do processo de produção e com a logística de transporte de insumos e produtos.

Um aspecto influenciador das decisões logísticas é a política de estoques da empresa. Kanafani (1983) destaca a interação entre tamanho da carga e frequência de movimentação com custos de armazenamento e custos de manipulação. Visando a minimização dos custos de sua atividade como um todo, uma empresa determinará o nível ótimo de armazenamento, a frequência de movimentação e o tamanho da carga. $O$ tamanho da carga, por sua vez, está diretamente relacionado com a modalidade de transporte, que possui um valor de frete e um nível de serviço específico. Sendo assim, Kanafani (1983) destaca que o nível ótimo de estoque depende do grau de confiabilidade no transporte (valor do desvio padrão do tempo em trânsito), da frequência de movimentação de cargas, do tempo em trânsito e do volume total a ser transportado em um dado período.

Os custos de transferência, para os usuários do serviço de transporte, correspondem ao valor cobrado pelo transportador pelos serviços necessários para a movimentação de uma determinada carga, mais os custos indiretos advindos dos atributos do serviço prestado. Os trabalhos encontrados na literatura tratam o custo de transferência por diversas denominações, tais como custo generalizado, custo efetivo, custo total de transporte e custo de distribuição (Johnson, 1976; Beilok \& Casavant, 1984; Novaes, 1984 e Min, 1991). No entanto, é senso comum a adoção do padrão referente à distinção entre custos diretos pagos pelo serviço e custos indiretos advindos dos atributos do serviço.

Johnson (1976), estimando a demanda por transporte de grãos, utilizou os custos indiretos advindos da variação do preço do produto durante o transporte; do capital imobilizado durante o transporte; da necessidade de manutenção de estoques extras, dada a não confiabilidade no serviço; da ocorrência de atrasos inesperados; e das perdas e danos não assegurados. Beilock \& Casavant (1984), trabalhando com o transporte de 
produtos agrícolas perecíveis, também utilizaram como custos indiretos o custo do capital imobilizado e a variação do preço da mercadoria durante o tempo em trânsito.

O custo de transferência de uma mercadoria para o usuário do serviço de transporte é, portanto, devido a vários fatores diretos e indiretos. A seguir, são apresentados os principais fatores originadores do custo de transferência, de acordo com Miklius et al. (1976), Kanafani (1983) e Min (1991):

- Frete - valor cobrado pelo serviço de transporte de uma mercadoria. É dependente da modalidade de transporte e casualmente do tamanho da carga e distância. Pode incluir custo de embarque, desembarque, seguro e embalagem.

- Armazenamento - valor pago pelo serviço de armazenagem de mercadorias durante o transporte. O custo de armazenamento geralmente depende do tipo de mercadoria e geralmente inclui o custo do capital imobilizado. Assim sendo, mercadorias de alto valor tendem a induzir estoques menores e modalidades de transporte mais rápidas.

- Tempo em trânsito - afeta o custo de transferência de duas formas principais. A primeira corresponde à perda de valor do produto durante o transporte, ocasionada por danos e variações no seu preço de mercado. A segunda corresponde ao custo do capital imobilizado durante o tempo em trânsito. que depende da taxa de juros relevante para o usuário.

- Transação - custos administrativos da contratação do serviço de transporte. Geralmente depende da empresa e da modalidade de transporte. Serviços de transporte contratados no longo prazo, normalmente, resultam em custos administrativos menores que os contratados de última hora.

- Confiabilidade - custos resultantes do nível de confiabilidade no processo logístico. A confiabilidade está associada, por exemplo, com o risco de ocorrência de atrasos no tempo previsto de trânsito.

- Embalagem - custo referente ao uso de embalagem para o transporte. É influenciado pelo tipo e velocidade da modalidade de transporte. que por sua vez devem estar adequados ao tipo de mercadoria transportada. 
- Manuseio - valor pago pelo serviço de embarque e desembarque da mercadoria. Esse custo pode estar incorporado no valor do frete e geralmente depende da modalidade de transporte e da tecnologia utilizada.

A valorização de um ou mais elementos do custo de transferência está associada às características da demanda de cada usuário dos serviços de transporte, como foi ressaltado no início da presente seção. A seguir, é abordada a interação entre o prestador e o usuário dos serviços de transporte, considerando-se as compensações existentes entre custo e qualidade do serviço para o ofertante e para o demandante.

\subsection{Aspectos da multimodalidade}

Como foi ressaltado, a multimodalidade pressupõe a movimentação de carga utilizando uma determinada combinação de modalidades de transporte. Espera-se que essa combinação seja realizada de forma a se agregar vantagens, que resultem em um serviço atrativo, quando comparado com um serviço unimodal. Min (1991) afirma que a multimodalidade pode oferecer condição para a redução dos custos de transferência e melhoria dos serviços. Por outro lado, o autor ressalta que pode ocorrer uma maior complexidade nesse tipo de serviço em função da maior variedade de opções e situações.

Fowkes et al. (1991) destacam que as vantagens oferecidas por uma alternativa multimodal devem ser suficientes para vencer a resistência do usuário, originária de uma série de fatores, inclusive subjetivos. Beilock \& Casavant (1984) destacam o posicionamento preconceituoso dos demandantes do transporte com relação à opção multimodal, que para a situação estudada tinha a qualidade sistematicamente subestimada.

Na maioria dos casos o transporte multimodal está associado a um aumento da distância a ser percorrida com relação à eventual ligação direta por via rodoviária, assim como conta com custos de transbordo incidindo sobre o custo de transferência. 
Fowkes et al. (1991) destacam que um dos objetivos da atividade de transporte multimodal deve ser a diminuição dos custos de transbordo. dada a sua importância na competitividade dessa alternativa.

Muitas vezes, os benefícios da multimodalidade são sociais, pois como destacam Fowkes et al. (1991), com o uso dessa alternativa de transporte, ameniza-se os congestionamentos e a poluição causada por fluxos pesados em longas distâncias rodoviárias. Beilock \& Casavant (1984) destacam como benefícios a maior eficiência no consumo de recursos, como por exemplo, combustivel e mão-de-obra.

Para que se possa dar consistência na análise das eventuais vantagens da alternativa multimodal sobre a unimodal, deve-se ter conhecimento das particularidades que regem cada uma dessas alternativas. Beilock \& (asavant (1984) destacam que a multimodalidade é muito mais afetada pela intensidade de uso do equipamento que o transporte rodoviário por caminhão. Ressaltam ainda que a menor flexibilidade na busca por cargas de retorno e a maior dificuldade de negociação sobre o preço do transporte, como desvantagens da multimodalidade. Nesse último caso, se o demandante tiver que negociar com cada um dos agentes atuantes no percurso, os custos de transação associados com o transporte multimodal poderão se tornar bastante elevados. Existem ainda os aspectos da regulamentação e fiscalização. que muitas vezes incidem de forma diferenciada sobre a multimodalidade e o transporte rodoviário.

Os elementos citados anteriormente influenciam a competitividade entre uma alternativa multimodal e uma ligação direta, na maioria dos casos rodoviária. Outros elementos também devem ser considerados, tais como a variação da distância e os custos terminais.

A resolução de um problema de escolha entre o transporte multimodal e unimodal deve necessariamente incluir os elementos citados anteriormente, mais os valores dos custos de transporte de cada uma das modalidades envolvidas. Desta forma, a vantagem do menor custo de transporte da modalidade principal utilizada na alternativa 
multimodal. ponderada pela distância percorrida. deve ser suficiente para cobrir o acréscimo na distância e os custos de transbordo.

\subsection{Análise da demanda por transporte}

De acordo com Kanafani (1983), a diversidade de padrões de interação socioeconômica e a resultante evolução da necessidade por transporte, são fatores que realçam a necessidade de uma análise formal e sistemática das relações entre distribuição espacial das atividades e transporte.

Segundo o autor, a demanda por transporte corresponde ao potencial de movimentação de cargas resultante das interações espaciais socioeconômicas. Por exemplo, o fluxo de carga por uma determinada modalidade de transporte, ou seja, o resultado da interação deste potencial por transporte com as características da modalidade disponivel para o transporte, é basicamente o objeto de estudo da análise da demanda por transporte.

As formas pelas quais se procede a análise de demanda por transporte de mercadorias podem ser agrupadas de très maneiras, de acordo com Kanafani (1983). A primeira refere-se à estrutura de modelagem microeconômica, na qual o principal agente de decisão é a empresa potencial usuária do transporte. Neste contexto, a demanda é derivada, considerando o transporte como um insumo de produção ou comercialização da empresa. A segunda refere-se à estrutura de modelagem econômica-espacial, uma visão agregada por natureza, onde excesso e déficit de mercadorias, localizados em vários pontos no espaço, são os geradores dos fluxos. A terceira refere-se à estrutura de modelagem macroeconômica, na qual as interrelações entre os setores de uma economia são analisadas.

Para este trabalho, será utilizada a estrutura de modelagem microeconômica, descrita com mais detalhes a seguir. 


\subsubsection{Estrutura de modelagem microeconômica}

Do ponto de vista da estrutura de modelagem microeconômica, as escolhas disponiveis para uma determinada firma incluem a localização, o nivel de produção, a substituição entre insumos e uma série de escolhas relacionadas ao transporte, tais como origem, destino, modalidade, frequência e tamanho das cargas (Kanafani, 1983). Esses mesmos elementos são destacados por Benjamin (1990), que os denominou de elementos de logística. Segundo o autor, as estratégias logísticas são parte de uma completa programação de produção, as quais afetam os custos de produção dos insumos em cada ponto de oferta e dos produtos finais em cada ponto de demanda. Desta forma, o custo total e o logístico devem ser minimizados.

De acordo com Kanafani (1983) e Koo \& Larson (1985), os principais instrumentais analíticos disponíveis para se modelar as escolhas relacionadas ao transporte de uma firma dizem respeito aos modelos de comportamento estocástico e aos modelos de otimização determinística.

No caso dos modelos de otimização determinística. destaca-se o modelo de fluxo de rede. que fundamenta-se na alocação dos fluxos de mercadorias nas rotas correspondentes ao menor custo total de transporte. Wagner (1986) destaca que os modelos de otimização de rede são economicamente significativos para muitas empresas comerciais que operam em várias instalações e mantêm estoques em armazéns locais. Cohen (1984) ressalta que algoritmos utilizados nos modelos de rede têm tornado tais ferramentas poderosas no auxílio à tomada de decisão por parte de uma firma.

De acordo com Koo \& Larson (1985), o modelo de rede é tipicamente formulado a partir de nós e arcos de interconexão, conforme representado na Figura 3.2. Nós representam elementos considerados no sistema e arcos conectam nós. Cada nó tem um custo unitário e restrições de capacidade. Segundo Wright (1980), dois são os pressupostos básicos do modelo de rede: a representação das regiões de origem e destino 
por nós. e a estimativa exógena de quantidades ofertadas e demandadas em cada região e período de tempo.

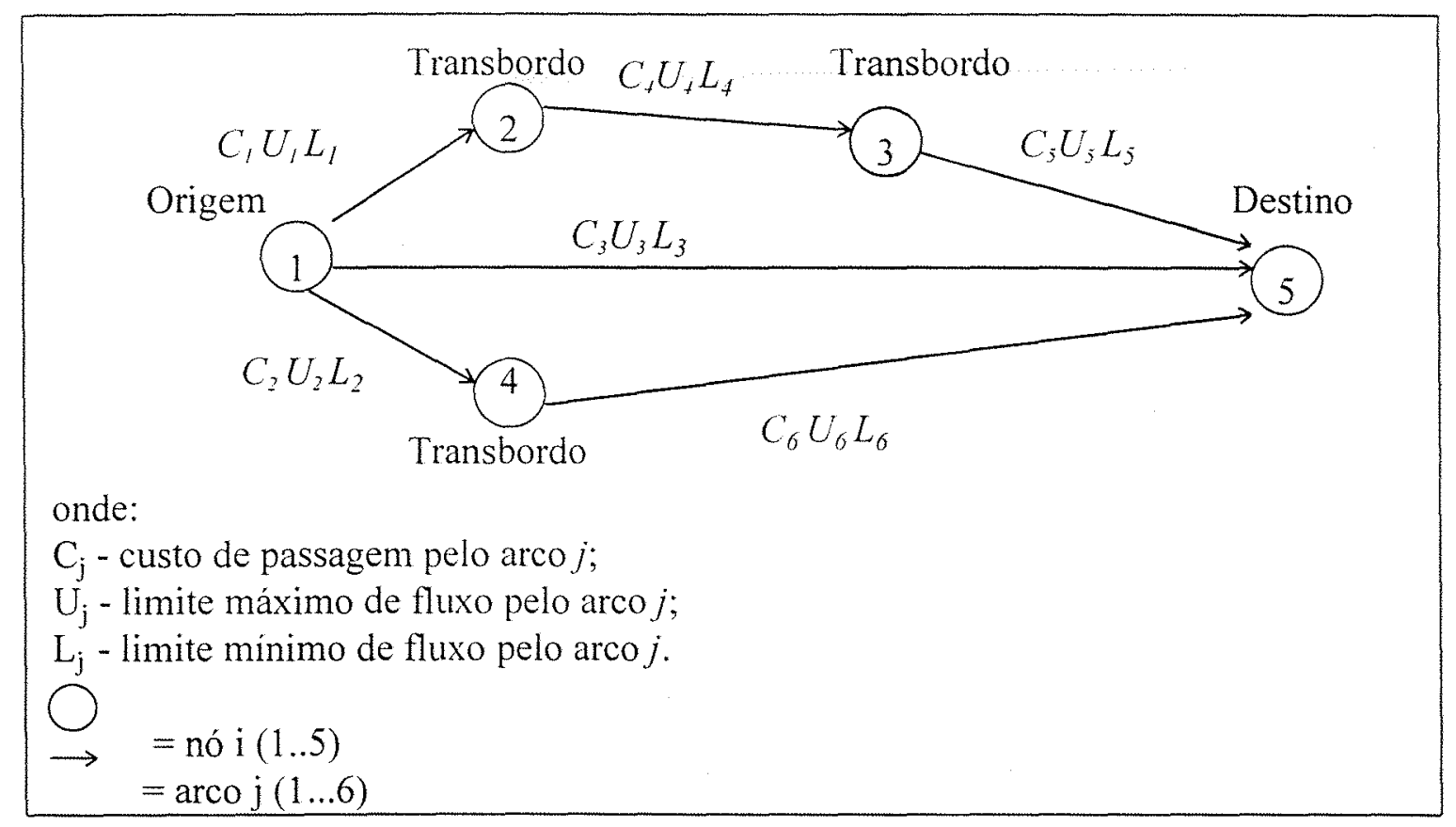

Figura 3.2 - Representação de um modelo de rede formado por 5 nós e 6 arcos de interconexão.

Uma série de características do problema de transporte podem ser contempladas através da modelagem de rede como, por exemplo, armazenamento, movimentação de vários produtos, cargas de retorno e custos crescentes ou decrescentes com o volume transportado.

A respeito da eficiência relativa dos algoritmos dos modelos de rede em comparação com a programação linear, Koo \& Larson (1985) observam que o primeiro é mais eficiente quanto ao tempo de processamento; por outro lado, também destacam que o modelo de rede não pode determinar, por exemplo, o local, número e tamanho ótimos de terminais. 
O GEIPOT (1993) utilizou um modelo de alocação de fluxos na análise da movimentação de grãos. operando com diversas modalidades e tendo como objetivo principal a redução dos custos de transporte. Foram realizadas simulações com base em cenários alternativos, sendo também analisados os motivos da não utilização de determinadas rotas.

O modelo de fluxo de rede foi utilizado por Veith \& Bronzini (1977) e Hawnn \& Sharp (1977) na determinação do caminho de menor custo para cada fluxo de mercadorias e, por consequência, na estimativa do tráfego no sistema hidroviário dos EUA. Como o sistema hidroviário corresponde a um elemento da rede multimodal de transporte americana, a previsão do tráfego foi realizada no contexto geral, o que se conseguiu através do modelo de fluxo de rede. Os fluxos foram definidos quanto a origem e destino, regiões, tonelagem, tipo de mercadoria e restrições de capacidade.

Benjamin (1990) analisou, através de um modelo de rede, o processo de escolha da modalidade de transporte para distribuição de mercadorias, incluindo na análise custos de produção, armazenamento, e transporte, mais restrições de demanda e capacidade. O problema foi formulado usando programação não-linear (função custo côncava) e as soluções ótimas foram obtidas através do algoritmo GINO (gradiente de redução generalizada) e também por um processo de decomposição. $O$ material manipulado no trabalho de Benjamin (1990) está de acordo com uma visão logística do problema, uma vez que inclui a preparação da matéria-prima, armazenamento no local de produção e transporte dos locais de produção para os de consumo.

Uma variação do modelo de fluxo de rede pode ser obtida na programação por metas. Utilizando a formulação padrão da programação linear, Min (1991) desenvolveu um modelo de programação por metas com restrições probabilísticas (chance-goal programming), para resolução de um problema de escolha da rota de transporte internacional mais adequada. Segundo o autor, a programação por metas com restrições probabilísticas se presta. com eficiência, ao auxílio da escolha da combinação de modalidades de transporte que minimizam custos e riscos. e também satisfazem vários 
requerimentos de nível de serviço. Ressalta ainda a importância da programação por metas na avaliação das relações de perdas e ganhos advindas da relação custo/nivel do serviço.

Com o modelo proposto. Min (1991) oferece uma ferramenta de avaliação de estratégias de distribuição. com diferentes combinações de modalidades de transporte, canais logísticos e requerimento de serviços em um ambiente estocástico. A modelagem também considera a facilidade de processamento, de acordo com os recursos computacionais disponíveis, evitando a formulação de problemas insolúveis.

Ainda do ponto de vista da abordagem microeconômica, tem-se o modelo de comportamento estocástico. também denominado como modelo comportamental. Segundo Kanafani (1983), mesmo que o agente relacionado com o transporte realize sua escolha de acordo com o princípio do mínimo custo, a aleatoriedade na função escolha passa a existir quando a não-representatividade dos custos é percebida ou mensurada.

De acordo com Novaes (1984), o modelo comportamental parte da teoria do consumidor. Segundo o autor, o consumo do serviço de transporte é composto por uma série de decisões em cascata, que dada a multiplicidade de fatores, constitui um ato mais complexo que a aquisição de produtos e bens duráveis.

Kanafani (1983) destaca que o modelo comportamental é utilizado no transporte de mercadorias com o mesmo sentido do transporte de passageiros. Assim, dependendo do conjunto disponível e da situação a ser modelada. a escolha pode ser binária ou multinomial.

A maioria dos modelos de comportamento está baseada no modelo logit ou no modelo probit, que normalmente são calibrados a partir de séries históricas de fluxos de mercadorias transportadas por modalidades distintas, ou a partir de dados de um conjunto de empresas individuais que se utilizam das modalidades estudadas. Miklius et al. (1976) utizaram-se de um modelo logit para explicar o método de escolha da modalidade de transporte, considerando o tipo de produto, o preço e a qualidade do serviço. A fonte de dados adveio de uma pesquisa sobre as movimentações dos 
produtos, onde foram observadas as parcelas referentes ì cada modalidade estudada, o valor do frete e tempo em trànsito. Como resultado. obtiveram a elasticidade-preço direta e cruzada pelo serviço de transporte. além do peso e correlação dos itens do serviço com a parcela de mercado da modalidade estudada.

Johnson, (1976) utilizou um modelo de comportamento estocástico para estimar a resposta da demanda por transporte e a seleção da modalidade de transporte face a mudanças na qualidade do serviço. Através de um questionário enviado às empresas armazenadoras de grãos. usuárias dos serviços de transporte pelas modalidades estudadas, o autor levantou o quanto e qual a proporção, em relação ao total, foi transportado por cada modalidade, assim como, a qualidade do serviço prestado. A demanda pelo transporte, dadas as pressuposições assumidas (preços constantes e volume transportado independente da sazonalidade do produto, e flutuações de preços), variou apenas devido à qualidade dos serviços prestados. Como resultado, o autor apresentou o peso de cada atributo do serviço de transporte sobre a sua demanda.

Assim sendo, como o presente trabalho volta-se para a análise do transporte hidroviário, baseada nos agentes envolvidos nesta atividade, será adotada a abordagem microeconômica da demanda por transporte. Mais particularmente, será utilizado o modelo de rede, dada a possibilidade de se manipular com a escolha entre modalidades de transporte sem a necessidade de calibração baseada em séries históricas, o que seria necessário (mas não disponível para este trabalho) caso se optasse pelo modelo comportamental.

\subsection{Considerações finais}

Como foi destacado no início do presente capítulo, a teoria apresentada será a base do desenvolvimento do trabalho e da análise dos resultados. Fundamentalmente, foram apontados os principais elementos teóricos relacionados aos agentes econômicos envolvidos com a atividade de transporte: os prestadores do serviço de transporte, os usuários e os órgãos govemamentais. 
Destacou-se que os estudos aplicados ao transporte devem considerar o padrão de inter-relacionamento entre os usuários e prestadores dos serviços de transporte, ambos influenciados pelas ações governamentais.

A prestação do serviço de transporte tem como elementos influenciadores a tecnologia, as estratégias de operação, as exigèncias e restrições institucionais e o comportamento do consumidor. Esses elementos agregados refletem-se em uma determinada qualidade de serviço ofertado, que depende da modalidade ou das modalidades de transporte utilizadas na movimentação de um produto. Para oferecer o serviço a uma dada qualidade, o prestador terá um custo. que é dividido entre custo de transporte, referente aos gastos diretamente proporcionais à distância, e custo terminal, que independe da distância percorrida.

Por outro lado, os usuários do serviço de transporte são agentes que demandam o transporte com o objetivo de atender as suas atividades econômicas, sendo a complexidade e a diversidade dessas atividades geradoras função de diferentes padrões de exigência. As características mercadológicas ou de comercialização dos produtos estudados, tais como a sazonalidade, a variação de preço e destino da carga; e as características físicas (perecibilidade, resistência ao manuseio, entre outras), estabelecem um perfil específico de demanda pelo transporte. Sendo assim, a identificação desses elementos permite distinguir as situações em que o transporte hidroviário seria menos ou mais interessante. Cada serviço de transporte representará um determinado custo de transferência para o usuário, que é dividido entre custo direto, que corresponde ao valor monetário desembolsado pelo usuário, e custo indireto advindo da qualidade do serviço ofertado.

Existem vários modelos que buscam representar as interrelações entre oferta e demanda pelo transporte, de forma a se determinar as alternativas de transporte mais vantajosas para cada caso. Alguns modelos exigem a utilização de dados históricos que caracterizem uma interrelação pré-existente. Por outro lado, na indisponibilidade dessa informação, outros modelos seriam mais recomendáveis. Uma forma de se verificar a 
competitividade entre as alternativas de transporte é através da identificação da alternativa que oferece o serviço mais barato para o usuário. o que pode ser obtido pelo modelo de rede apresentado. Com base nas diferenças de custo de transferência para o usuário, determinadas entre as modalidades, pode-se inferir possivveis interrelações entre oferta e demanda.

Foram destacados também as particularidades da alternativa de transporte multimodal, a qual pode incluir a modalidade de transporte hidroviário. Com exceção da modalidade de transporte rodoviária, a ferroviária e a hidroviária devem necessariamente ser integradas com outra modalidade, na maioria dos casos a rodoviária, para que se possa atingir a origem e o destino desejados. Esse fato gera uma série de implicações que diferenciam a alternativa de transporte multimodal da unimodal, que devem ser levadas em consideração na interpretação da competitividade entre essa alternativas. 


\section{MATERIAL E MÉTODOS}

De acordo com o objetivo principal definido, o presente trabalho busca informações sobre o problema de transporte hidroviário de grãos, de forma a se retratar os fenômenos e as relações existentes, para o caso especifico da Hidrovia Tietê-Paraná. Propõe-se, desta forma, uma pesquisa exploratória-descritiva do problema de transporte hidroviário, sobre o qual serão feitas descrições quantitativas e qualitativas.

Segundo Gil (1988), a pesquisa exploratória tem como objetivo proporcionar maior familiaridade com o problema, para torná-lo mais explícito através, por exemplo, de formulação de hipóteses. Marconi \& Lakatos (1990) destacam que a pesquisa exploratória tem tripla finalidade: desenvolver hipóteses, aumentar a familiaridade do pesquisador com um ambiente e modificar ou esclarecer conceitos. Marconi \& Lakatos (1990) destacam ainda, que da pesquisa exploratória obtêm-se descrições tanto quantitativas quanto qualitativas do objeto de estudo.

Marconi \& Lakatos (1990) destacam dentro da pesquisa exploratória o estudo exploratório-descritivo, que corresponde ao estudo de um caso através de análises empíricas e teóricas.

Yin (1988) lembra que o estudo de caso se presta a responder às perguntas "Como" e "Por que" para eventos contemporâneos, sobre os quais se tem pouco ou nenhum controle, contribuindo de forma singular para o conhecimento do indivíduo, organização, sociedade e fenômenos políticos.

A forma de coleta de dados através de entrevista focalizada. onde segue-se um roteiro de tópicos a serem discutidos com o entrevistado, será uma das formas escolhidas para o presente trabalho. Marconi \& Lakatos (1990) destacam que nesse tipo de entrevista as perguntas são abertas e podem ser respondidas dentro de uma conversação 
informal. A forma de coleta de dados via questionário também será utilizada, para o levantamento de informaçōes complementares ao estudo principal.

Outras fontes de informação também serão utilizadas, seguindo o princípio da multiplicidade de fontes de evidências, ressaltado por Yin (1988) como uma importante conduta da coleta de dados. Desta forma. serão utilizadas as informações obtidas nas entrevistas, nos questionários e algumas outras obtidas em organizações de classe e órgãos gestores governamentais.

Como o estudo de caso prevê a generalização analítica dos resultados e não a estatística, Yin (1988) argumenta que lógicas de amostragem não se aplicam ao estudo de caso. Segundo o autor. o estudo de caso não deveria ser usado para verificar a incidência de um fenômeno e sim para cobrir o fenômeno e o seu contexto. O método de generalização analítica utiliza-se da teoria previamente apresentada como padrão de comparação dos resultados empíricos da pesquisa. Esse aspecto também é ressaltadò por Markoni \& Lakatos (1990), que afirmam que na pesquisa exploratória as técnicas de entrevista (observação participativa, análise de conteúdo, entre outras) se destinam ao estudo relativamente intensivo de um pequeno número de unidades, geralmente sem o emprego de técnicas probabilísticas.

Com base nas diretrizes estabelecidas pelo estudo de caso delineado, os procedimentos descritos a seguir serão realizados.

\subsection{Caracterização da oferta}

De acordo com o objetivo especifico de estabelecer a natureza da oferta pela identificação dos custos e características do serviço, foi procedido o levantamento de dados, via entrevista, junto aos principais agentes envolvidos.

O levantamento junto aos prestadores do serviço de transporte hidroviário, foi realizado através de entrevista com gerentes das empresas transportadoras atuantes na 
Hidrovia Tietê-Paraná com o transporte dos produtos estudados (soja em grão. milho em grão e farelo de soja).

As empresas contatadas foram escolhidas mediante um levantamento prévio realizado junto à publicações do setor, em especial da CESP.

Através de contato telefônico e solicitaçào por escrito, foi agendada entrevista nas sedes das empresas. O roteiro de entrevista visou explorar os seguintes tópicos:

- características gerais da empresa;

- origem e destino das cargas transportadas (na hidrovia e ponta-à-ponta);

- estrutura da empresa (embarcações, terminais);

- custos associados com o transporte e a operação de terminais;

- nivel de serviços oferecido, considerando-se os principais atributos: tempo em trânsito, perdas e danos, variação do tempo em trânsito, confiabilidade, serviços personalizados;

- relacionamento com o cliente;

- relacionamento com outras modalidades;

- problemas operacionais internos da empresa e com a operação da hidrovia;

- capacidade e quantidades transportadas durante o ano.

As informações solicitadas foram utilizadas na caracterização do serviço de transporte, em seus vários aspectos, de acordo com a teoria apresentada anteriormente.

Também foi realizada uma análise dos custos que os prestadores do serviço de transporte hidroviário vêm observando, verificando-se a influência das principais variáveis nesses custos. Os cálculos foram realizados para o comboio tipo Tietê, considerando-se os arranjos simples e duplo de barcaças.

Como elementos do custo fixo do comboio, foram considerados os seguintes itens:

- custo de amortização do capital investido. calculado da seguinte forma; 


$$
A=\left[C_{i}(1+r)^{n}-C_{f}\right] \frac{r}{(1+r)^{n}-1}
$$

onde: $\quad C_{i}$ - custo inicial;

$C_{f}$ - valor final do bem;

$r$ - taxa anual unitária de juros;

$n$ - número de anos de duração do capital

- custo da tripulação, considerando duas equipes por embarcação (a mão-deobra empregada na operação das embarcações deve ser especializada na atividade, o que faz com que as empresas normalmente estabeleçam contratos permanentes de prestação de serviço);

- custo de seguros e impostos;

- custos administrativos;

- custos de manutenção.

Os elementos do custo variável do comboio, ou seja, aqueles custos incorridos apenas se houver a movimentação da embarcação. são apresentados a seguir:

- custos com alimentação;

- custos com combustível;

- custos com lubrificantes.

- custos com impostos cobrados pelo uso da hidrovia.

Tendo os custos fixos e variáveis sido calculados por viagem, procedeu-se o cálculo dos custos unitários (US\$/t.km), considerando-se as variações advindas da intensidade de utilização do equipamento, nas suas duas dimensões - o número de viagens-ano e a porcentagem de viagens realizadas com a embarcação carregada.

A variação do custo unitário advinda da intensidade de utilização do equipamento se origina da diluição dos custos fixos, como mostra a equação (2): 


$$
C u=\frac{C f}{n}+C v
$$

onde: $C u$ - custo unitário por viagem;

$C f$ - custo fixo para o comboio;

$C v$ - custo variável total por viagem;

$n$ - número de viagens.

Como fonte complementar de informação para a referida análise, foram coletados dados junto aos órgão gestores, a CESP e a Capitania Fluvial da hidrovia Tietê-Paraná.

Foram levantadas informações referentes a:

- taxação da movimentação de cargas;

- movimentação mensal dos produtos estudados;

- movimentação por empresa;

- custos terminais e de transferência estimados pela CESP, quando na elaboração do projeto original da Hidrovia Tietê-Paraná.

Tais dados foram utilizados como complemento para a análise dos custos com que as empresas prestadoras do serviço estão operando. As informações sobre a movimentação de cargas por empresa e por embarcação foram utilizadas na caracterização da estrutura de mercado. Os dados sobre o número de viagens e proporção entre viagens carregadas/vazias foram considerados como parâmetros para a mensuração do desempenho da atividade e, assim sendo, aferidores dos custos dessa atividade. Quanto às estimativas de custos de transferência, utilizadas pela CESP na elaboração do projeto original da Hidrovia Tietê-Paraná, estas foram utilizadas para confrontação com os valores efetivamente pagos pelos atuais usuários daquela via de transporte. 


\subsection{Caracterização da demanda}

A determinação do perfil do usuário do transporte hidroviário dos produtos estudados foi efetuada através da investigação sobre as empresas usuárias do serviço de transporte da Hidrovia Tietê-Paraná, para movimentação de grãos de soja, grãos de milho e farelo de soja.

Foi realizado contato com as empresas identificadas como usuárias, buscando o agendamento de uma entrevista, cujo roteiro visou explorar as seguintes informações:

- aspectos gerais da atividade da empresa, em especial a importância do serviço de transporte;

- origem e destino das cargas transportadas pela hidrovia;

- época da movimentação de cargas;

- quantidade demandada de transporte (mensal);

- relação entre a frequência de movimentação, o tamanho de carga e a política de estoques;

- atributos observados na escolha do serviço utilizado;

- custos de transferência observados (custo diretos e indiretos considerados no cálculo);

- valores pagos pelo serviço e valores de serviços alternativos não utilizados;

- problemas enfrentados na utilização do serviço hidroviário;

- perspectivas de utilização futura.

Através da análise desses aspectos, objetivou-se determinar o perfil da demanda pelo serviço de transporte hidroviário de soja em grão, milho em grão e farelo de soja, baseando-se nos aspectos de mercado e logística das empresas. Como foi citado anteriormente, as características de mercado do produto influenciam a escolha do serviço de transporte, como por exemplo, a variação do preço, o destino (mercado interno, 
mercado externo) e a estrutura de mercado. Ao mesmo tempo, a logística da empresa, como a estratégia de estoques e a frequência e tamanho da carga, também exercem influência na escolha do serviço de transporte.

Também foram consideradas na caracterização da demanda as informações provenientes de usuários de serviços de transporte alternativos ao oferecido na hidrovia Tietê-Paraná, para os mesmos produtos. A forma de coleta de dados, adotada para essa etapa, foi através de questionário enviado às empresas. O questionário, apresentado no Apêndice, foi enviado ao departamento de logística das empresas selecionadas, procurando extrair as seguintes informações:

- origem e destino das movimentações dos produtos estudados;

- problemas enfrentados no uso dos serviços de transporte;

- valores pagos pelo serviço;

- custos diretos e indiretos considerados na movimentação dos produtos;

- atributos considerados na escolha do serviço de transporte.

\subsection{Verificação da competitividade do transporte hidroviário}

Com a caracterização da oferta e da demanda pelo transporte dos produtos estudados na hidrovia Tietê-Paraná, as informações levantadas foram processadas através de um modelo de rede.

Gualda (1985) utilizou um modelo de rede para analisar a competitividade entre alternativas de transporte no Estado de São Paulo, em particular, na área de abrangência da Hidrovia Tietê-Paraná. Veith \& Bronzini (1977), Hawnn \& Sharp (1977), Wright (1980), Benjamin (1990) e GEIPOT (1993), também utilizaram modelos de rede na determinação de rotas de menor custo.

O modelo básico de rede, normalmente adotado, consiste na representação da realidade através de nós e arcos de interconexão. Os nós representam os pontos de produção, demanda e transbordo; e os arcos representam as alternativas de transporte, possíveis de serem utilizadas, entre dois pontos considerados. 
A estrutura matemática do modelo de rede pode ser representada pelas expressões (3), (4) e (5), de acordo com SAS Institute Inc. (1989):

$$
\min \mathbf{c}^{\mathrm{T}} \mathbf{x}
$$

sujeito a

$$
\begin{aligned}
& \text { F } x=b \\
& I \leq x \leq u
\end{aligned}
$$

onde:

$\mathrm{a}=$ número de $\operatorname{arcos}(j=1 \ldots a)$

$\mathrm{n}=$ número de nós $(i=1 \ldots n)$

$\mathbf{c}=$ vetor de dimensão $(a \times l)$, representativo dos custos associados aos fluxos pelos $\operatorname{arcos} j$

$\mathbf{x}=$ vetor de dimensão $(a \times l)$, associado com variáveis resposta, que correspondem aos fluxos de carga por cada arco

$\mathbf{F}=$ matriz de coeficientes $(n \times a)$, identificadores do fluxo da rede

onde: $\mathrm{F}_{i j}$ é igual a -1 se o arco $j$ tem nó $i$ como destino

1 se o arco $j$ tem o nó $i$ como origem

0 para os demais casos

$\mathbf{b}=\operatorname{vetor}(n \times l)$ representativo das quantidades ofertadas e demandadas

onde: $b_{i}$ é igual a $s$ se o nó $i$ tem capacidade de ofertar " $s$ " unidades de fluxo

- d se o nó $i$ demanda "d" unidades de fluxo

0 se o nó $i$ for um nó de passagem

$\mathrm{I}=$ vetor $(a \times I)$ indicador do fluxo mínimo permitido pelos arcos

$\mathbf{u}=$ vetor $(a x l)$ indicador do fluxo máximo permitido pelos arcos

Pela expressão número (3), impõe-se a minimização da totalidade dos custos associados às movimentações de carga pelos arcos. Por outro lado, para que seja garantida a coerência quanto à sequência de arcos que definem uma alternativa multimodal, utiliza-se a restrição representada pela equação (4). Com tal equação, garante-se a escolha de um arco (alternativa unimodal) ou de vários arcos (alternativa multimodal), sendo que para o segundo caso todos os arcos escolhidos fazem parte de uma mesma alternativa. 
O custo de transferência, para o usuário do serviço de transporte, pode incorporar elementos associados com os custos diretos e indiretos de movimentação de uma mercadoria. No entanto. em função da dificuldade de mensuração quantitativa dos custos indiretos, procedimento esse que extrapola o propósito do presente trabalho, esses não serão incluídos no vetor de custo $\mathbf{c}$.

Quanto aos limites máximos e mínimos de fluxos pelos arcos, definidos pelos vetores $\mathbf{u}$ e I na equação (5), esses foram considerados iguais a um valor muito alto e a zero, respectivamente. Desta forma, não serão considerados no modelo de rede adotado as restrições de capacidades de transporte próprias de cada modalidade. Assim sendo, ao se pretender dar uma visão competitiva entre as alternativas, as capacidades das modalidades de transporte não foram consideradas como limitantes para este estudo.

Portanto, o modelo adotado deve determinar as rotas de menor custo de transferência entre os vários pares de origem/destino considerados, conforme explicitado na expressão (3).

Os pressupostos assumidos para a modelagem adotada são comentados a seguir:

- a localização de cada uma das regiões produtoras pode ser representada por um nó.

- as origens e destinos foram definidas previamente. ou seja, tais variáveis são exógenas ao modelo.

- o custo de transferência independe da quantidade movimentada. As capacidades das alternativas de transporte não serão consideradas, não avaliando-se assim o impacto da quantidade movimentada sobre o custo de transferência.

- o custo de transferência é proporcional à distância de transporte. Dada a inexistência de informação de valores de frete cobrados para todas as rotas estudadas foi estimada a relação existente entre os valores de frete e distância percorrida, através de regressão linear. Outros fatores, tal como a qualidade 
das vias, não foram considerados como influenciadores do custo de transferência.

- não existe diferença do valor de frete cobrado entre os produtos (soja em grão, milho em grão e farelo de soja). Assumiu-se que os três produtos são tipicamente graneis sólidos. não implicando em tecnologia de transporte diferenciada.

Como o objetivo da modelagem utilizada é avaliar alguns aspectos da competitividade do transporte hidroviário ou da alternativa multimodal que inclua essa modalidade, optou-se por trabalhar com o custo de transporte para o prestador do serviço hidroviário, e com os valores praticados no mercado pelas outras modalidades. Desta forma, considerou-se que os preços das outras modalidades são conhecidos (exógenos) para a empresa de transporte hidroviário, fazendo com que o custo de transporte seja o único elemento com que a empresa possa trabalhar para se posicionar competitivamente frente ao mercado.

\subsubsection{Especificação dos dados}

As informações necessárias para a estruturação de um modelo de rede dizem respeito basicamente à a estrutura viária disponivel para a ligação entre dois pontos separados espacialmente e aos preços para a utilização do serviço de transporte.

Com base nas informações obtidas na caracterização da oferta e demanda pelo transporte hidroviário, foram definidos os pares de origem e destino utilizados na elaboração dos vários modelos de rede. Basicamente, os pares de origens e destinos trabalhados podem ser agregados em dois grupos:

- rotas com destino ao porto de Santos e origem nas regiões produtoras de soja em grão, milho em grão e farelo de soja localizadas no sul de Goiás e no Mato Grosso;

- rotas com origem no sul de Goiás e destino às cidades do Estado de São Paulo. 
Adotou-se como custo de passagem por um determinado arco $c_{j}$ o valor de frete médio anual praticado no mercado pelas modalidades rodoviária e ferroviária. Para o caso da modalidade hidroviária, adotou-se o custo unitário de transporte associado com o tipo e nível de utilização do equipamento, calculado no presente trabalho.

Dada a necessidade de valores de frete rodoviário praticados para várias rotas, inclusive rotas ainda não exploradas, optou-se por estimar uma equação que relacionasse a distância com o valor do frete. Para estimar tal equação, foram obtidos de Soares \& Caixeta (1996), os dados primários coletados para soja em grão, farelo de soja e milho em grão, referentes ao período de outubro de 1993 a outubro de 1996. A estimativa fundamentou-se no ajustamento de uma função significativa e de maior coeficiente de determinação $\left(R^{2}\right)$. Esse procedimento foi utilizado em vários trabalhos, entre eles Fowkes et al. (1991), Michaels et al. (1982) e Vitale (1980), que estimaram equações relacionando o valor cobrado pelo frete e a distância percorrida.

Para o caso dos valores praticados pelo transporte ferroviário, foram levantadas informações junto à FEPASA, sobre os valores cobrados para o transporte dos produtos estudados.

\subsubsection{Processamento}

O processamento das informações foi realizado utilizando-se o módulo de pesquisa operacional do software "SAS - Statistical Analysis System" (SAS Institute Inc., 1989). Neste software, o processamento de modelos de rede se utiliza de um algoritmo específico, uma variante do algoritmo simplex revisado que explora a estrutura do modelo de rede para reduzir o tempo de processamento.

Como os modelos utilizados podem ser considerados bastante simples, no sentido do número de nós e arcos entre um par de origem e destino, o tempo de processamento não representou problema para o presente trabalho (no Apêndice são apresentados o programa e a saída de resultados). 
A sequência de processamento e o fluxo de informaçòes podem ser visualizados no esquema apresentado na Figura 4.1.

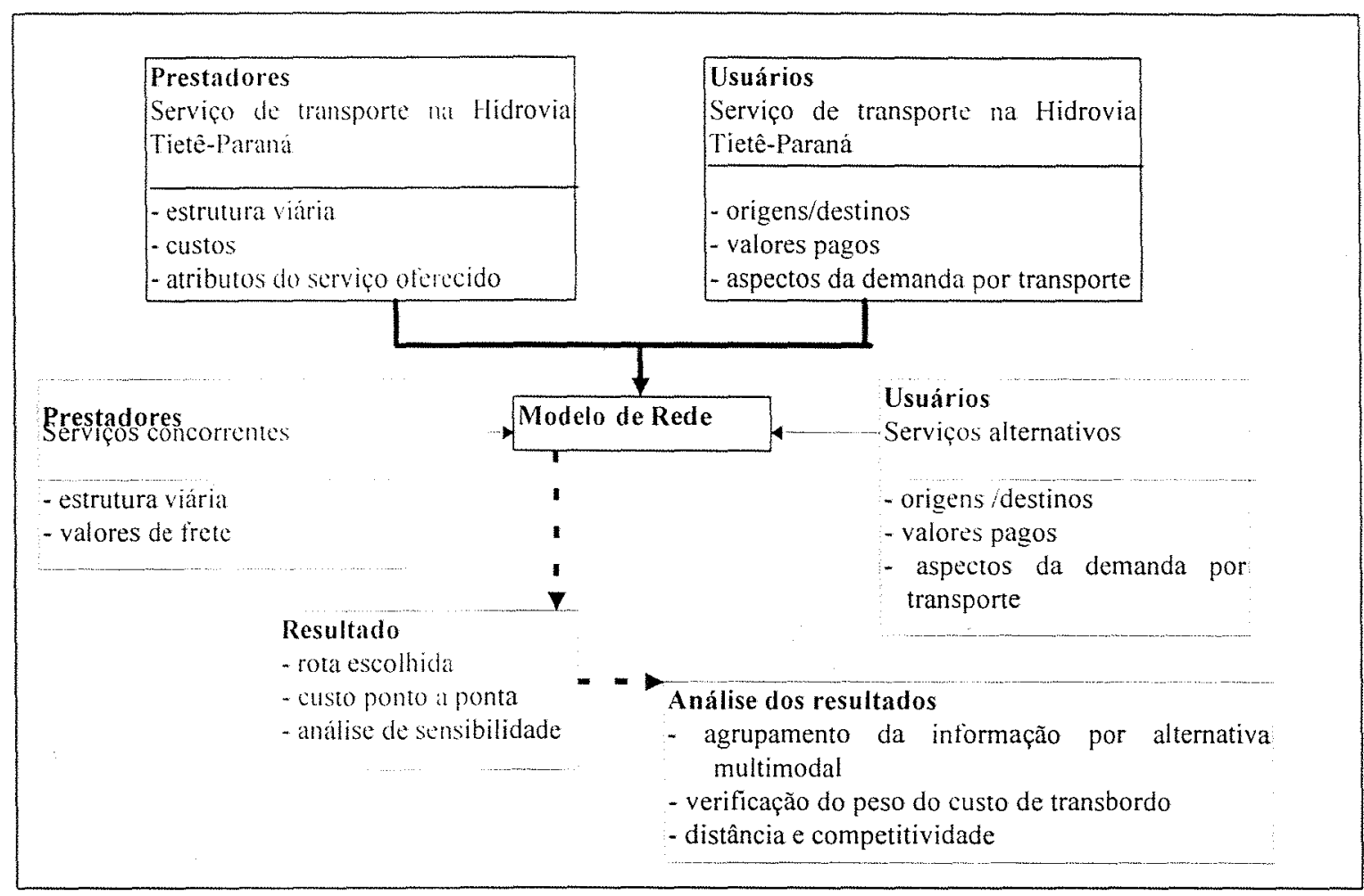

Figura 4.1 - Diagrama de fluxo de informações do modelo proposto.

\subsection{Considerações finais}

Com as informações básicas coletadas junto aos prestadores do serviço de transporte hidroviário e aos seus respectivos demandantes, foram definidos os custos hidroviários e os pares de origem/destino. Junto aos usuários de serviços de transporte concorrentes, às pesquisas de valores de frete e junto a prestadores de serviço de outras modalidades, complementou-se o total de informações básicas para a elaboração do modelo.

Os resultados foram analisados segundo as possibilidades competitivas da alternativa multimodal frente à alternativa unimodal rodoviária, procurando-se salientar as variáveis influenciadoras da competitividade. 


\section{RESULTADOS E DISCUSSÃO}

Conforme os procedimentos apresentados no capítulo anterior, foram levantadas as informações apresentadas nos itens a seguir.

Na caracterização da oferta do serviço de transporte hidroviário, as informações foram obtidas através de entrevista em três empresas transportadoras hidroviárias, assim como também foram realizados os cálculos dos custos de prestação do serviço e da influência da intensidade do uso do equipamento sobre estes.

$\mathrm{Na}$ caracterização da demanda pelo transporte hidroviário, as informações foram obtidas através da entrevista com três empresas demandantes do transporte hidroviário e através do questionário (apresentado no Apêndice) respondido por seis empresas demandantes de outras modalidades de transporte.

Por fìm, foi realizada a verificação da competitividade do transporte hidroviário frente às outras alternativas disponíveis, a partir do conjunto de origens e destinos definido pelas informações coletadas junto aos prestadores e usuários do transporte hidroviário.

\subsection{Caracterização da oferta}

Foram detectados três grupos básicos de empresas atuantes no transporte de grãos e farelos na hidrovia Tietê-Paraná:

- empresa de transporte comercial que presta serviços a terceiros, mediante remuneração pela cobrança do frete; 
- empresa de transporte de carga própria, que executa o transporte de produtos de sua propriedade e por ela comercializados;

- empresa de transporte de carga própria e comercial, que além de transportar carga própria. presta serviços utilizando sua capacidade excedente de transporte.

Na hidrovia. segundo dados fornecidos pela Capitania Fluvial da Hidrovia TietêParaná, existem atualmente cinco empresas habilitadas para o transporte de produtos agrícolas.

Das empresas entrevistadas, a empresa "A" 14 pertence ao primeiro grupo, e já atua na atividade de transporte hidroviário há mais de 30 anos, quando ainda a navegação ocorria apenas nos trechos naturalmente navegáveis. Os produtos transportados por essa empresa são o álcool, a soja em grão, o milho em grão, o farelo de soja e os bens manufaturados acondicionados em "containers". Além da atividade de transporte hidroviário, a empresa atua no transporte rodoviário, integrado ou não com o hidroviário, como também contrata serviços de terceiros.

Esta empresa tem atuado nos trechos da hidrovia entre São Simão (GO) e Anhembi (SP), entre Presidente Epitácio (SP) e Hernandeiras (Paraguai) e entre Araçatuba (SP) e Santa Maria da Serra (SP).

Na Tabela 5.1 são apresentados os produtos transportados nos trechos da hidrovia onde a empresa "A" atua, incluindo as respectivas origens e destinos.

Tabela 5.1. Rotas de transporte operadas pela empresa "A".

\begin{tabular}{cccc}
\hline Trecho na hidrovia & Produto & Origem & Destino \\
\hline São Simão - Anhembi & soja em grão & sul de Goiás & Mairinque, Santos \\
São Simão - Anhembi & farelo de soja & São Simão & Laranjal Paulista, Tietê, Tatuí e \\
& & Santos \\
São Simão - Anhembi & milho em grão & São Simão & Laranjal Paulista, Tietê, Tatuí \\
Araçatuba $-\mathrm{S}^{\text {ta }}$. Maria da Serra & álcool & Araçatuba & Paulínia \\
Hernandeiras - Pres. Epitácio & soja em grão & Paraguai & Santos \\
Pres. Epitácio-Hernandeiras & produtos & Santos & Assunção \\
& manufaturados & & \\
\hline
\end{tabular}

14 Os nomes das empresas entrevistadas serão omitidos propositalmente, com o objetivo de cumprir o compromisso de sigilo assumido no momento da entrevista. 
Por outro lado, as empresas entrevistadas "B" e "C" encaixam-se no segundo e terceiro grupo, respectivamente. Essas empresas internalizaram totalmente a atividade do transporte hidroviário, para atender as necessidades de movimentações relacionadas com a sua atividade principal, que é a exportação de soja em grão e a comercialização de milho em grão no mercado interno. Para tal, foram realizados investimentos completos em terminais, armazéns, embarcações, formação de pessoal e incorporação de outras empresas. O transporte complementar tem sido realizado pelas modalidades rodoviária e ferroviária, através da contratação de terceiros ou através de contratos específicos de parceria.

Na Tabela 5.2 são apresentados os produtos e as respectivas origens e destinos, referentes ao transporte realizado pelas empresas " $\mathrm{B}$ " e " $\mathrm{C}$ ".

Tabela 5.2 - Rotas e produtos transportados pelas empresas " $\mathrm{B}$ " e "C".

\begin{tabular}{cccc}
\hline Trecho na hidrovia & Produto & Origem & Destino \\
\hline São Simão - Pederneiras & soja em grão & sul de Goiás & Santos \\
São Simão - Pederneiras & farelo de soja & São Simão & Santos \\
São Simão - Araçatuba & soja em grão & sul de Goiás & Osvaldo Cruz \\
São Simão $-S^{\text {ta }}$. Maria da & soja em grão & sul de Goiás & Santos \\
Serra & & & \\
São Simão $-S^{\text {ta }}$. Maria da & milho em grão & sul de Goiás & Santa Maria da Serra \\
Serra & & & \\
\hline
\end{tabular}

Basicamente, as cargas agrícolas (soja em grão, milho em grão e farelo de soja), objetos do presente estudo, são transportadas do sul de Goiás para o Estado de São Paulo, percorrendo os rios Paranaíba no chamado Tramo Norte, e o rio Tietê no chamado Tramo Tietê. No chamado Tramo Sul da hidrovia (rio Paraná), ocorre o transporte de soja em grão do Paraguai com destino a Santos. As cargas oriundas do sul de Goiás são movimentadas com o objetivo de atender ao mercado interno do Estado de São Paulo e ao mercado externo através do porto de Santos.

As cargas agrícolas são transportadas normalmente em um único sentido: das regiões mais interiores às mais próximas do litoral. Essa é uma característica essencial 
do transporte realizado por essas empresas, o que praticamente implica a não exploração de cargas de retorno.

As empresas atuantes no transporte de soja em grão, farelo de soja e milho em grão são praticamente especialistas no transporte desses produtos, com exceção da empresa "A", que apresentou uma maior variedade de produtos transportados, como também de rotas utilizadas. Segundo Burg \& Daley (1985), as empresas de transporte hidroviário norte-americanas trabalham com vários produtos ao mesmo tempo, o que facilita a conjugação de cargas de retorno, e a diminuição da ociosidade do equipamento. Assim sendo, a especialização em apenas um produto pode não ser interessante para as empresas nacionais.

\subsubsection{Estrutura de operação}

Conforme as observações realizadas, a estrutura mínima necessária para operação na hidrovia inclui os terminais privados de embarque e desembarque, dotados de piers de atracação, silos, equipamentos de transbordo de carga, empurradores fluviais e barcaças.

Os terminais de embarque e desembarque da Hidrovia Tietê-Paraná são, em sua maioria, de propriedade das empresas transportadoras. Os principais terminais são os de São Simão, Pederneiras, Araçatuba, Santa Maria da Serra e Anhembi.

No terminal de São Simão, em um distrito agroindustrial, estão instalados os terminais privados de todas as empresas estudadas. A partir deste terminal, considerado o mais representativo em termos de embarque de soja, milho e farelo de soja provenientes das zonas produtoras do sul de Goiás, há conexão com a modalidade rodoviária.

Em Araçatuba. o terminal tem sido operado pela empresa "C". Este terminal, de conexão rodoviária. tem sido usado como local de desembarque de carga de terceiros, especificamente soja em grão e milho em grão. 
No terminal de Pederneiras, pertencente à empresa "C", está instalado um terminal multimodal de conexão rodoviária e ferroviária, que tem sido usado como ponto de transbordo das cargas que se dirigem para o porto de Santos, e como ponto central de operação de várias empresas.

Em Santa Maria da Serra, já no rio Piracicaba, há o terminal de conexão rodoviária, pertencente à empresa "B", que tem sido utilizado para o transbordo de soja em grão com destino ao porto de Santos e para a comercialização de milho em grão na região.

Em Anhembi está localizado o terminal de transbordo de cargas, com conexão rodoviária, pertencente à empresa "A". Este tem sido usado para o transbordo de soja em grão e milho em grão com destino à região e ao porto de Santos.

Quanto às embarcações, embora o comboio de navegação deva seguir limites máximos, determinados pelas dimensões das eclusas e pela profundidade das vias fluviais, foi observado que as empresas têm se utilizado de comboios diferentes. Três tipos básicos foram determinados:

- o comboio de $1.600 \mathrm{t}$, composto por quatro barcaças de $400 \mathrm{t}$ (calado de $1,5 \mathrm{~m}$ ) dispostas em linha, movimentadas por um empurrador dotado de dois motores de $450 \mathrm{hp}$;

- comboio de $2.200 \mathrm{t}$, composto por quatro barcaças de $830 \mathrm{t}$ (calado de $3,2 \mathrm{~m}$ ) dispostas em linha e movimentadas por um empurrador dotado de dois motores de $450 \mathrm{hp}$. Em função do calado máximo do trecho Tietê, as barcaças estão transportando em média 530 t com o calado de $2 \mathrm{~m}$;

- comboio de $2.200 \mathrm{t}$, composto por duas barcaças de $1.100 \mathrm{t}$ dispostas em linha e movimentadas por empurrador dotado de dois motores de $450 \mathrm{hp}$.

Observa-se que a potência dos empurradores é a mesma para todas as empresas. Ocorre, no entanto, que esta potência pode ser considerada excessiva para a quantidade de carga transportada. Segundo dados apresentados pela CESP (1995b), a potência 
mínima propulsiva de 900 hp está associada a um deslocamento de carga da ordem de 4.000 t. Balau (1978) apresenta uma equação de cálculo de potência para empurradores, que aplicada às condições do comboio de $2.200 \mathrm{t}$ (barcaças de $58 \mathrm{~m}$ por $11 \mathrm{~m}$, calado de $2,5 \mathrm{~m}$, velocidade de deslocamento de $12 \mathrm{~km} / \mathrm{h}$ ) resulta no valor de $620 \mathrm{hp}$.

Desta forma, as empresas têm-se utilizado de embarcações mais potentes do que seria necessário para a carga movimentada por elas, o que acarreta custos maiores por tonelada transportada.

Uma formação alternativa, utilizada por duas das empresas entrevistadas, é o comboio duplo, que se utiliza de duas barcaças adicionais, implicando no dobro da quantidade transportada. Esse tipo de composição permite explorar melhor a potência dos empurradores, uma v'ez que existe um excedente não utilizado. Uma desvantagem é a necessidade de executar a eclusagem em duas etapas, o que acarreta maior tempo de viagem.

A navegação utilizando comboios duplos, no entanto, não tem sido permitida sob a alegação de problemas de segurança. Estudos mais detalhados nessa área específica da engenharia naval devem ser realizados, tendo em vista a possibilidade de aumentar a eficiência do atual transporte hidroviário de cargas.

\subsubsection{Características do transporte realizado}

A respeito das características do serviço de transporte hidroviário, foram levantadas informações junto às empresas.

Na Tabela 5.3 são apresentados alguns tempos de viagem para os principais pares de origens e destinos da hidrovia, obtidos através dos agentes entrevistados. Um elemento que afeta o tempo de viagem é o número de eclusagens necessárias para atravessar cada trecho da hidrovia. Em condições normais, a eclusagem é realizada em 30 minutos. 
Tabela 5.3 - Tempo de viagem para as principais rotas de transporte utilizadas pelas empresas entrevistadas.

\begin{tabular}{lcccc}
\hline \multicolumn{1}{c}{ Origem c destino } & $\begin{array}{c}\text { Distância } \\
(\mathbf{k m})\end{array}$ & $\begin{array}{c}\text { No de } \\
\text { eclusas }\end{array}$ & $\begin{array}{c}\text { Tempo de } \\
\text { eclusagem } \\
\text { (h) }\end{array}$ & $\begin{array}{c}\text { Tempo } \\
\text { médio de } \\
\text { viagem (h) }\end{array}$ \\
\hline São Simão - Araçatuba & 380 & 0 & 0 & 27 \\
São Simão - Pederneiras & 640 & 5 & 2,5 & 56 \\
São Simão - Sta. Maria da Serra & 720 & 6 & 3 & 63 \\
São Simão - Anhembi & 759 & 6 & 3 & 76 \\
\hline *Tempo para comboio simples ce eclusagem dia e noite & & &
\end{tabular}

Outro atributo importante é a porcentagem de perdas ocorridas durante o transporte. Todos os prestadores do serviço de transporte hidroviário foram unânimes em afirmar que a porcentagem de perdas varia entre 0,2 e $0,5 \%$. Quanto às perdas qualitativas, especialmente dos grãos, não há consenso quanto às vantagens ou desvantagens do transporte hidroviário. De acordo com os prestadores do serviço de transporte, a operação de carga e descarga com armazenamento intermediário pode diminuir a qualidade do produto. No entanto, a comparação entre os danos qualitativos à carga para as modalidades distintas de transporte merece um estudo mais aprofundado.

\subsubsection{Conduta em relação ao usuário}

Outra característica do serviço a ser destacada é a conduta das empresas em relação ao usuário. Em vista disto, foram levantados alguns atributos considerados importantes pelas empresas, no sentido do oferecimento de um serviço adequado ao usuário.

O serviço porta-à-porta, pelo qual a empresa oferece o serviço de transporte da origem ao destino final, sem a necessidade do usuário contratar serviços de transporte complementares, foi destacado como um importante fator no sentido do oferecimento de um serviço competitivo. 
As empresas também consideram importante a garantia de confiabilidade do serviço para o usuário. Por confiabilidade, as empresas entendem o cumprimento dos prazos e o baixo nível de perdas.

Destacou-se ainda a importância da capacidade de oferecer um fluxo contínuo de movimentação de cargas como um fator associado ao incremento da satisfação das necessidades dos usuários.

A busca por novos clientes é ainda bastante incipiente por parte dos prestadores do serviço de transporte hidroviário. Não foram detectadas iniciativas de busca de novos clientes fundamentadas em procedimentos de "marketing". De uma maneira geral, os clientes são poucos e bem conhecidos.

Quanto às relações contratuais entre prestador e usuário do serviço de transporte, as empresas de transporte comercial têm firmado contratos de curto prazo. Contratos de longo prazo, onde o prestador e o usuário firmam compromissos conjuntos visando a obtenção de benefícios em um horizonte maior, não foram relatados. Aparentemente, os contratos têm sido de caráter experimental, principalmente para o usuário do serviço.

Nota-se que a empresa "A", mediante as relações contratuais observadas, tem pouca garantia de volume de carga a ser transportado. Observou-se inclusive que as empresas consideram a alternativa rodoviária como uma forte concorrente, dificultando o estabelecimento de contratos de longo prazo. Por outro lado, contratos de curto prazo implicam em incertezas e ociosidade de equipamento por parte das empresas transportadoras.

Como o transporte hidroviário pressupõe uma integração estreita entre o usuário e o prestador do serviço, as características observadas são elementos complicadores da eficiência de tal atividade. 


\subsubsection{Custos de transporte}

Como foi destacado na teoria apresentada anteriormente, o custo de transferência para os prestadores do serviço de transporte hidroviário, também chamado de custo de produção, pode ser dividido em custos de transporte e custos terminais. Por razões de disponibilidade de informação, o custo de transbordo não será calculado no presente trabalho, quando for necessário a sua utilização, serão utilizados valores médios adotados da literatura.

Para o custo de transporte, a ocorrência de diferentes valores entre as empresas do setor pode ser associada a vários fatores, entre eles a tecnologia utilizada, as estratégias de operação (intensidade de utilização do equipamento), as exigências e restrições institucionais e o comportamento do consumidor.

A tecnologia utilizada nas embarcações de transporte de carga deve seguir padrões específicos, determinados pelos órgãos gestores, levando em conta as características do canal e das eclusas. Embora tenham sido observados vários tipos de comboios, a diferença principal encontra-se no tipo e arranjo das barcaças. $\mathrm{O}$ empurrador, elemento propulsor dos comboios, apresenta basicamente as mesmas características. Sendo assim, a tecnologia de transporte, no que diz respeito às embarcações utilizadas, não apresenta diferenças significativas entre as empresas.

$\mathrm{Na}$ verificação da intensidade de utilização do equipamento foram coletadas informações sobre a frequència de movimentação (número de viagens por ano) e a porcentagem de viagens realizadas com o comboio carregado (porcentagem de carregamento). Para a porcentagem de carregamento, observou-se o valor médio de $50 \%$, correspondendo ao transporte de carga quase que exclusivamente em apenas um sentido. Basicamente, as embarcações têm transportado grãos e farelos oriundos das regiões produtoras do sul de Goiás com destino ao Estado de São Paulo, retornando vazias. Por outro lado, o número de viagens possíveis de serem realizadas por ano, de acordo com as condições reais imperantes, pode ser visualizado na Tabela 5.4. 
Tabela 5.4 - Nímero de viagens possiveis do comboio simples, por trecho de operação, segundo as condições vigentes no ano de 1996.

\begin{tabular}{lcc}
\hline \multicolumn{1}{c}{ Origem e destino } & No de viagens/mês & No de viagens/ano \\
\hline São Simão - Araçatuba & 9 & 90 \\
São Simão - Pedemeiras & $7-8$ & $70-80$ \\
São Simão - Sta. Maria da Serra & $6-7$ & $60-70$ \\
São Simão - Anhembi & $6-6,6$ & $60-66$ \\
\hline
\end{tabular}

Os valores observados diferem dos considerados pela CESP (1994), que na elaboração dos cálculos para o comboio tipo Tietê, assumiu 94 viagens por ano e $85 \%$ das viagens de ida e $40 \%$ das viagens de volta realizadas com plena carga, ou seja, a porcentagem de carregamento foi de $62,5 \%$.

Considerando o número de viagens possíveis de serem realizadas (Tabela 5.4) e o fato da não exploração de cargas de retorno, foram realizadas novas estimativas de custos para o comboio simples. Os parâmetros básicos adotados nos cálculos dos custos são apresentados na Tabela 5.5, sendo as informações apresentadas obtidas junto aos entrevistados e também na literatura consultada.

Tabela 5.5 - Parâmetros básicos adotados no cálculo dos custos de transporte.

\begin{tabular}{|c|c|c|}
\hline Parâmetro & Valor & Unidade \\
\hline Consumo de combustível & 0,18 & l/hp/h \\
\hline Consumo de lubrificante $^{2}$ & 0,167 & $\mathrm{l} / \mathrm{h}$ \\
\hline Vida útil do empurrador ${ }^{1}$ & 15 & anos \\
\hline Vida útil das barcaças ${ }^{2}$ & 30 & anos \\
\hline Taxa de seguro & 1,6 & $\%$ sobre o valor do empurrador \\
\hline Manutenção' & 4 & $\%$ sobre o valor do comboio \\
\hline Taxa de juros & 10 & $\%$ ao ano \\
\hline Tripulação $^{2}$ & 6 & pessoas \\
\hline
\end{tabular}
Fontes: I - Balau ( 1978) e 2 - CESP (1994)

Na Tabela 5.6 são apresentados os valores monetários considerados no cálculo dos custos de transporte. 
Tabela 5.6 - Valores monetários adotados no cálculo dos custos de transporte.

\begin{tabular}{lrc}
\hline Item & Valor (US\$) & Unidade \\
\hline Empurrador (900hp) & $1.500 .000,00$ & por empurrador \\
Barcaça (1100t) & $500.000,00$ & por barcaça \\
Salário tripulação & $4.000,00$ & mensal \\
Óleo diesel & 0,44 & por litro \\
Óleo lubrificante & 2,70 & por litro \\
\hline
\end{tabular}

Conforme os padrões regularmente adotados, foram consideradas duas tripulações por embarcação, uma vez que o sistema de trabalho corresponde a um período de atuação e um de folga.

$\mathrm{Na}$ Tabela 5.7 são apresentados os custos fixos anuais para o comboio simples, calculados segundo a especificação descrita na metodologia.

Tabela 5.7 - Custos fixos anuais do comboio simples.

\begin{tabular}{|c|c|c|}
\hline $\begin{array}{l}\text { Custos anuais fixos } \\
\text { Amortização do capital }\end{array}$ & & Valor (US\$) \\
\hline \multirow[t]{2}{*}{ Amortização do capital } & empurrador & $187.768,53$ \\
\hline & barcaça & $104.863,40$ \\
\hline Tripulação & & $168.960,00$ \\
\hline Seguros ( $1.6 \%$ do valor do comboio $)^{1}$ & & $40.000,00$ \\
\hline Impostos (IPVA) & & $2.500,00$ \\
\hline Manutenção ( $4 \%$ do valor do empurrador) ${ }^{1}$ & & $60.000,00$ \\
\hline Administrativos ( $10 \%$ do gasto com a tripulação) $)^{2}$ & & $16.896,00$ \\
\hline Total & & $580.987,93$ \\
\hline
\end{tabular}

As porcentagens adotadas foram retiradas de: 1- Balau (1978) e 2 - CESP (1994)

$\mathrm{Na}$ Tabela 5.8 são apresentados os custos variáveis, calculados para uma viagem de $759 \mathrm{~km}$ entre São Simão(GO) e Anhembi(SP), de acordo com os parâmetros apresentados anteriormente. 
Tabela 5.8 - Recursos consumidos pelo comboio simples para a viagem entre São Simão e Anhembi $(759 \mathrm{~km})$.

\begin{tabular}{|c|c|c|}
\hline Item & Valor & $\begin{array}{c}\text { Porcentagem em relação } \\
\text { ao total }\end{array}$ \\
\hline Número de horas de viagem & $79,75 \mathrm{~h}$ & \\
\hline Combustível & US\$ $5.684,58$ & 79,10 \\
\hline Lubrificante & US\$ $\quad 35,96$ & 0,50 \\
\hline Alimentação & 500,00 & 6,96 \\
\hline Taxa de percurso* & 966,24 & 13,44 \\
\hline Custo variável total por viagem & US\$ $7.186,78$ & 100,00 \\
\hline
\end{tabular}

A partir dos custos fixos e variáveis apresentados anteriormente, foi calculado o custo unitário (US\$/t.km), considerando a variação do número de viagens entre 10 e 94 e as porcentagens de carregamento iguais a 47,5,50,62,5 e 75\%, para o percurso entre São Simão e Anhembi. Considerou-se também o custo adicional advindo da taxa de percurso igual a R\$ $0,0008 / \mathrm{t} . \mathrm{km}$, incidente sobre as embarcações carregadas, que trafeguem no trecho de jurisdição da CESP. Os valores obtidos a partir do cálculo realizado são apresentados no Anexo (Tabelas 3 e 4).

O comportamento do custo unitário de transporte em função do número de viagens realizadas, por ano, por embarcação, dadas diferentes porcentagens de carregamento, pode ser visualizado na Figura 5.1.

Pode-se verificar na Figura 5.1 a influência do número de viagens e da porcentagem de carregamento sobre o custos unitários de transporte. À medida que o número de viagens aumenta, o custo diminui a taxas decrescentes para cada patamar de porcentagem de carregamento. A taxa de redução para cada incremento unitário no número de viagens varia de $32,63 \%$ a $4,15 \%$ nas primeiras 20 viagens, passa para $1,76 \%$ na $40^{a}$ viagem e termina com $0,53 \%$ na $94^{a}$ viagem. 


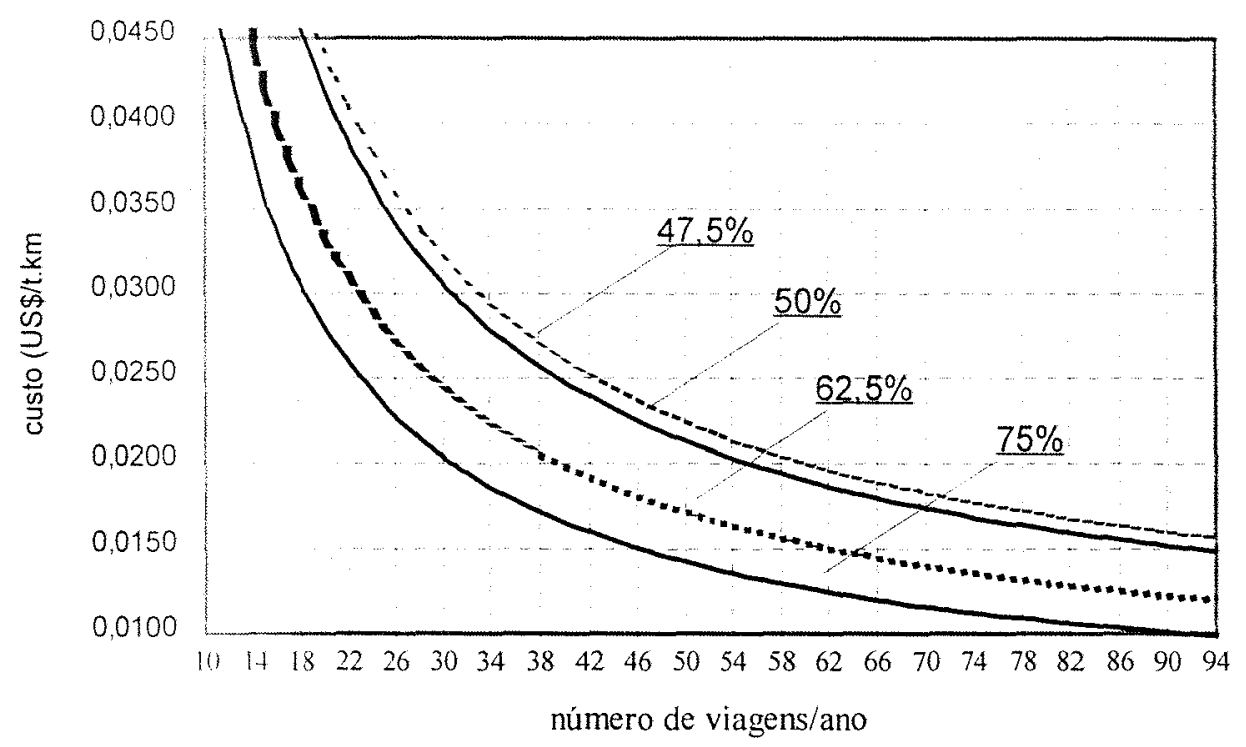

Figura 5.1 - Comportamento do custo unitário de transporte em função do número de viagens realizadas por ano, por embarcação, considerando-se diferentes porcentagens de carregamento.

De acordo com os cálculos realizados, dados $62,5 \%$ de carregamento, a redução de $30 \%$ no número de viagens (94 para 66) aumenta o custo unitário em $20 \%$ (US\$ $0,0125 / \mathrm{t} . \mathrm{km}$ para US\$ $0.0150 / \mathrm{t} . \mathrm{km})$. Por outro lado, para um número de viagens fixo igual a 66 , a redução de $37 \%$ na porcentagem de carregamento ( $75 \%$ para $47,5 \%$ ) aumenta o custo unitário em 55\% (US\$ 0,0126/t.km para US\$ 0,0195/t.km).

A influência conjunta do número de viagens e da porcentagem de carregamento gerou diferenças ainda maiores no custo unitário. Por exemplo, o custo unitário para 94 viagens com $75 \%$ de carregamento (US\$ $0,0105 / \mathrm{t} . \mathrm{km}$ ) foi $54 \%$ menor que o custo unitário para 66 viagens com 47,5\% de carregamento (US\$ 0,0195/t.km).

Os mesmos cálculos foram realizados para o comboio duplo, de forma a se constatar as vantagens advindas do aumento de $100 \%$ da capacidade de carga. Os custos fixos considerados nos cálculos são apresentados na Tabela 5.9. Nota-se que o aumento advém do maior capital investido em barcaças, do seguro e dos impostos. 
Tabela 5.9 - Custos anuais fixos do comboio duplo.

\begin{tabular}{llcc}
\hline \multicolumn{1}{c}{ Custos fixos } & $\begin{array}{c}\text { Valor } \\
\text { (US\$) }\end{array}$ & $\begin{array}{c}\text { Variação em relação ao } \\
\text { comboio simples (\%) }\end{array}$ \\
\hline Amortização do capital & empurrador & $187.768,53$ & 0 \\
& barcaça & $209.726,80$ & 100 \\
Tripulação & & $168.960,00$ & 0 \\
Seguros & $56.000,00$ & 40 \\
Impostos (IPVA) & $3.600,00$ & 44 \\
Administrativo & $16.896,00$ & 0 \\
Manutenção & $60.000,00$ & 0 \\
\hline Total & $\mathbf{7 0 2 . 9 5 1 , 3 3}$ & $\mathbf{2 1}$ \\
\hline
\end{tabular}

Os custos variáveis por hora não foram alterados. No entanto, o custo variável calculado para uma viagem, sofreu alteração advinda do maior tempo em trânsito, ocasionado pela diminuição da velocidade e pela eclusagem dupla (que exige o desmembramento do comboio para sua realização). Na Tabela 5.10 pode-se visualizar a alteração dos custos variáveis em relação ao comboio simples, para uma viagem de 759 km entre São Simão e Anhembi.

Tabela 5.10 - Recursos consumidos pelo comboio duplo para a viagem entre São Simão e. Anhembi $(759 \mathrm{~km})$.

\begin{tabular}{|c|c|c|c|c|}
\hline Item & Va & Ior & Variação em & Porcentagem com \\
\hline Número de horas de viagem & & $107,5 \mathrm{~h}$ & 35 & \\
\hline Combustível & US\$ & $7.662,60$ & 35 & 74,80 \\
\hline Lubrificante & US\$ & 48,47 & 35 & 0,47 \\
\hline Alimentação & US\$ & 600,00 & 20 & 5,86 \\
\hline Taxa de percurso* & US\$ & $1.933,63$ & 100 & 18,87 \\
\hline Custo variável total por viagem & US\$ & $10.244,70$ & 43 & 100,00 \\
\hline
\end{tabular}

Calculando-se os custos unitários (US $\$ / t . k m$ ) para o comboio duplo, observou-se uma redução média de $36.7 \%$ com relação ao comboio simples (dados apresentados nas Tabelas 3 e 4 do Anexo). independente do número de viagens e da porcentagem de 
carregamento. Existe, portanto, uma economia significativa proveniente do aumento da capacidade de transporte do comboio, uma vez que o aumento de $100 \%$ da capacidade implica no aumento menos que proporcional nos custos unitários. Este fato advém de uma melhor adequação da potência do empurrador com a capacidade de carga.

\subsubsection{Operação da hidrovia}

Sobre a operação da hidrovia foram destacados alguns aspectos importantes que afetam diretamente a atividade dos prestadores do serviço de transporte hidroviário. $\mathrm{O}$ horário de funcionamento das eclusas foi um elemento determinante do tempo de viagem e do número de viagens possíveis por ano. Segundo os prestadores do serviço hidroviário, ocorrem períodos de inoperância de eclusas na hidrovia Tietê-Paraná, devido a três motivos básicos: funcionamento diário somente das $7 \mathrm{~h}$ às $22 \mathrm{~h}$; fechamento por um mês para manutenção de equipamentos e fechamento ocasionado por excesso de vazão. No ano de 1996, até o mês de agosto, contabilizando apenas o horário de funcionamento, o tempo de paralisação por eclusa foi de 2.322 horas ou 96,75 dias.

Observando-se dados internacionais sobre o período de inoperância de eclusas, pode-se ter idéia da importância da magnitude do tempo de paralisação. Na Tabela 5.11 são apresentados alguns tempos de paralisação para as principais hidrovias americanas.

Tabela 5.11 - Tempo médio de paralização das eclusas das principais hidrovias dos EUA (1995).

\begin{tabular}{lccc}
\hline \multicolumn{1}{c}{ Hidrovia } & $\begin{array}{c}\mathbf{N}^{0} \text { médio de } \\
\text { paralisações }\end{array}$ & $\begin{array}{c}\text { Tempo médio por } \\
\text { paralisação (h) }\end{array}$ & $\begin{array}{c}\text { Tempo médio total de } \\
\text { paralisação (dias) }\end{array}$ \\
\hline Alto Mississippi & 31 & 18 & 17 \\
Ohio & 32 & 16 & 9 \\
Tennessee & 73 & 12 & 24 \\
Illinois & 33 & 14 & 22 \\
\hline
\end{tabular}

Fonte: Navigation Data Center ${ }^{15}$

15 Serviço mantido pelo "U.S. Army Corp of Engineers" na Internet, endereço: http://www.wrcnrc.usage.army.mil/ndc 
Nota-se que nas eclusas das principais hidrovias dos EUA, embora tenha ocorrido tempo médio de paralisação de até 24 dias, tal período apresentou-se dividido em períodos menores que um dia, o que reflete a preocupação com a não interrupção do fluxo de embarcações. Cabe destacar que nas hidrovias do Mississippi e de Ohio, as de maior movimento de cargas, a maioria dos pontos de eclusagem são dotados de duas eclusas, uma principal e outra auxiliar, o que diminui ainda mais o impacto dos tempos de paralisação.

Outro aspecto da operação da hidrovia refere-se à forma de resgate dos investimentos e gastos com as vias navegáveis (sinalização, manutenção, etc.). A CESP utiliza como fonte de financiamento dos gastos com a operação da hidrovia, a taxação da movimentação de cargas, proporcional ao número de eclusagens realizadas.

No caso de grãos e farelos, até agosto de 1996 era cobrada a taxa de $\mathrm{R} \$ 0,10 /$ t/eclusa, o que implicava em um total de $\mathrm{R} \$ 1.320,00$ para uma viagem do comboio carregado com $2.200 \mathrm{t}$ entre São Simão e Anhembi. Em função de uma série de problemas, o método de cobrança foi modificado para a aplicação de taxa de percurso igual a $\mathrm{R} \$ 0,0008 / \mathrm{t} . \mathrm{km}$, para as embarcações que transitarem carregadas no trecho sob jurisdição da CESP. Essa nova taxa corresponde a $\mathrm{R} \$ 966,24$ para uma viagem entre São Simão e Anhembi com carga de 2.200 t, valor este que corresponde a 13,44\% dos custos variáveis de uma viagem.

Em outros países são praticados três tipos de taxação de uso de hidrovias: a taxa sobre o combustível, a taxa de passagem (pedágio) e a taxa de eclusagem. Nos EUA, segundo o serviço de informação "Navigation Data Center"16 tem-se adotado a taxa sobre o combustível, que foi gradativamente aumentando de US\$ 0,0106/1 em 1980 para US\$ 0,0528/1 após 1994. O montante arrecadado é direcionado para o "Inland Waterways Trust Fund", que financia as operações de manutenção e reabilitação das vias hidroviárias.

16 Serviço mantido pelo "U.S. Corp of Engineers" na internet, endereço http://www.wrcnrc.usage.army.mil 
Uma viagem de ida e volta entre São Simão e Anhembi, implicaria em um valor a ser pago de US\$1.267,00, caso fosse aplicada a taxa dos EUA (US\$ 0,0528/1) e um valor de US\$ 966,2417 e US\$ $1.932,48^{17}$ caso fosse aplicada a taxa nacional, respectivamente, para viagem com carga em apenas um sentido e viagem com carga nos dois sentidos.

O resgate dos investimentos e gastos na hidrovia é, sem dúvida, de suma importância na organização da atividade. No entanto, devem ser considerados os vários aspectos relacionados com o impacto das taxas sobre a atividade, em especial, os efeitos do custo do frete na competitividade em relação a outras modalidades.

\subsubsection{Considerações finais}

Na caracterização da oferta do serviço de transporte hidroviário, detectou-se três tipos básicos de empresas atuantes, que operam transportando carga do sul de Goiás às cidades do Estado de São Paulo e ao porto de Santos. Essas empresas, com uma exceção, transportam exclusivamente soja, milho e farelo de soja, oriundos das mesmas regiões. Com relação à estrutura de operação, detectou-se o total controle das empresas, desde as embarcações até os terminais de carga e descarga.

Quanto à conduta com relação ao usuário, não foram observados contratos de longo prazo, estabelecidos entre demandantes e prestadores do serviço. Com exceção das cargas próprias das empresas, os prestadores trabalham com uma expectativa de demanda bastante incerta, o que pode representar um fator elevador dos custos de transporte.

A intensidade de utilização do equipamento, representada pelo número de viagens e pela porcentagem de carregamento, revelou-se como grande influenciadora dos custos unitários (US\$/t.km) tanto para o comboio simples como para o duplo. O

\footnotetext{
17 Considerando o câmbio de USS $1,00=\mathrm{R} \$ 1,00$.
} 
comboio duplo, por outro lado, apresentou custos unitários 37\% menores que o comboio simples.

Foram detectados três tipos de influência da operação da hidrovia sobre a atividade das empresas: o regime de funcionamento das eclusas; a restrição ao uso do comboio duplo e a cobrança da taxa de percurso.

\subsection{Demanda pelo transporte hidroviário}

A demanda por transporte na hidrovia Tietê-Paraná apresenta movimentação diferenciada de cargas ao longo do tempo. No gráfico apresentado na Figura 5.2, podese visualizar que o volume agregado, que inclui cargas como areia, álcool, soja, calcário, cana, milho, trigo, farelo de soja e adubo, apresenta demanda diferenciada durante o período. Nota-se que entre dezembro e fevereiro a demanda por transporte é inferior à demanda dos meses de março a novembro.

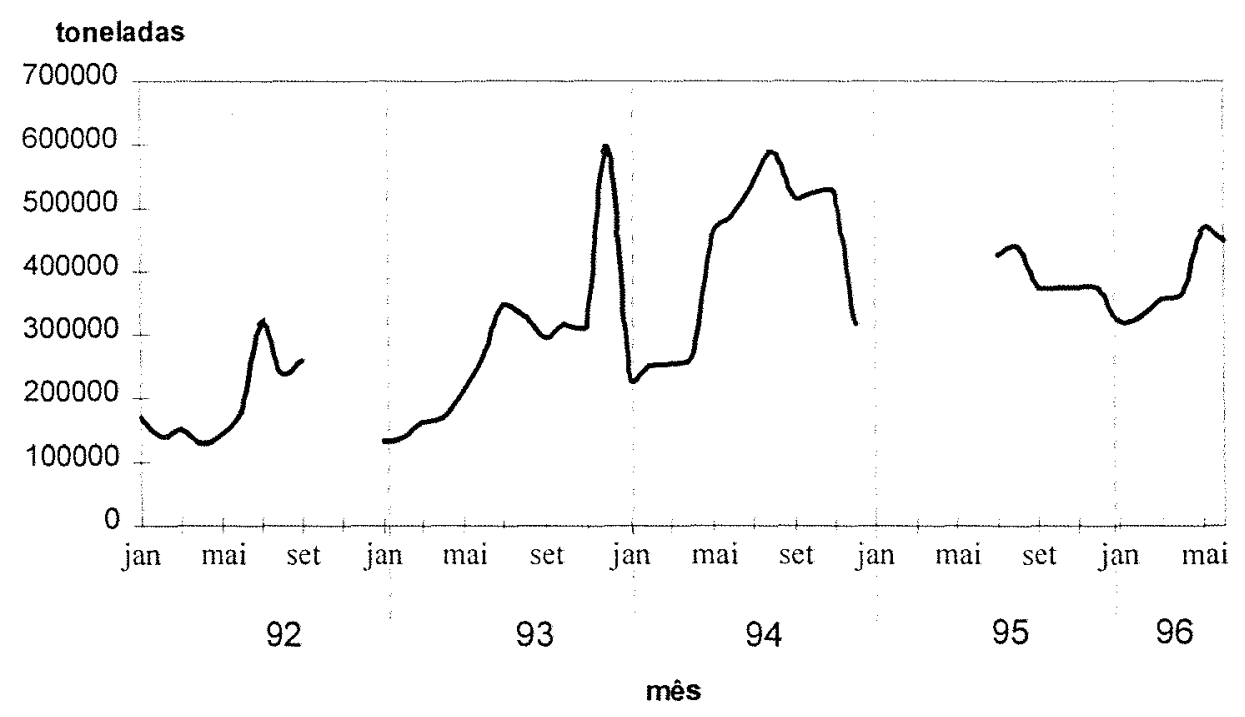

Figura 5.2 - Movimentação mensal de cargas eclusadas na hidrovia Tietê-Paraná, de janeiro de 1992 a abril de 1996 (Fonte: CESP18).

18 Dados fornecidos, pela Diretoria de Hidrovias e Desenvolvimento Regional da CESP. 
O aspecto sazonal da movimentação de cargas também pode ser averiguado através dos dados de eclusagem de embarcações de transporte de carga, apresentados na Figura 5.3. Nota-se que o número de eclusagens aumenta a partir de março e reduz-se a partir de outubro-novembro.

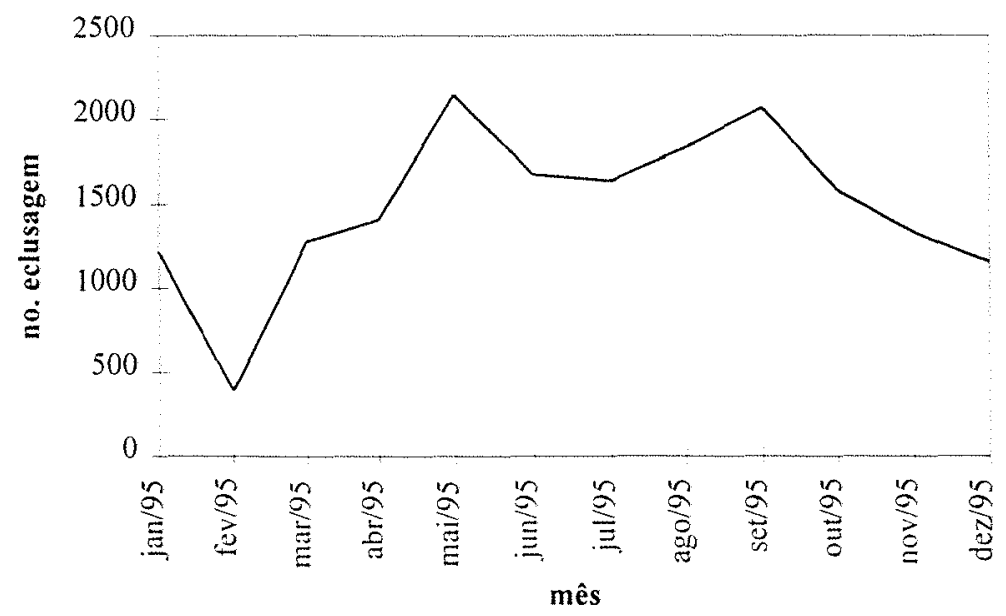

Figura 5.3 - Número de embarcações eclusadas, na hidrovia Tietê-Paraná, por mês durante o ano de 1995 (Fonte: CESP $^{18}$ ).

A sazonalidade da demanda por produto, em virtude da falta de dados disponíveis, deve ser analisada com cautela. No entanto, pode-se visualizar na Figura 5.4 que a movimentação de soja em grão apresenta uma tendência clara de aumento no período que se inicia em março. Para o milho em grão e o farelo de soja, por outro lado, não há tal tendência, ocorrendo inclusive uma certa constância no volume transportado. 


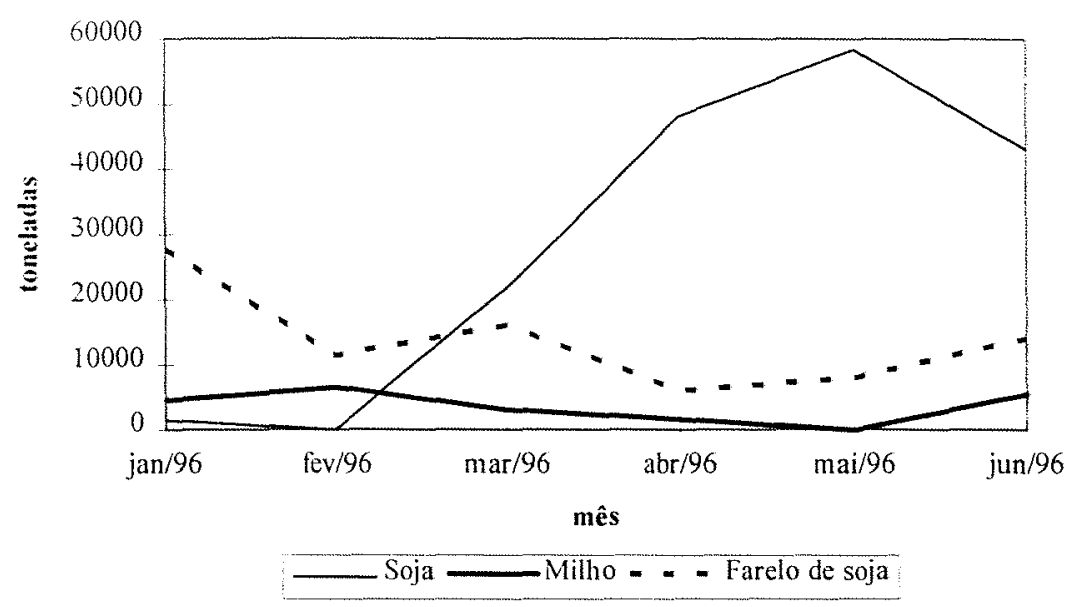

Figura 5.4 - Movimentação mensal de cargas eclusadas por produto na hidrovia TietêParaná, período de janeiro de 1996 a junho de 1996 (Fonte: CESP' ${ }^{19}$ ).

As empresas que atualmente têm demandado o serviço de transporte oferecido na hidrovia Tietê-Paraná, podem ser divididas em três grupos básicos:

- empresas comercializadoras de soja em grão e milho em grão, que para o caso em particular, optaram pela internalização do serviço de transporte hidroviário;

- empresas produtoras de óleo de soja que demandam o serviço de transporte hidroviário para abastecer a unidade industrial com matéria-prima (soja em grão);

- empresas produtoras de óleo de soja, que demandam o serviço de transporte hidroviário para escoar a produção de farelo de soja.

A demanda pelos serviços de transporte advém das atividades econômicas e sociais separadas espacialmente. Sendo assim, é importante a verificação dos aspectos mercadológicos dos produtos com que as empresas trabalham.

Dos produtos considerados, a soja em grão e o milho em grão são produtos oriundos diretamente do setor agrícola, ou seja, possuem a característica de produção

${ }^{19}$ Dados fornecidos. pela Diretoria de Hidrovias e Desenvolvimento Regional da CESP. 
sazonal. Por outro lado, o farelo de soja, sendo proveniente do setor industrial, apresenta produção constante durante $o$ ano todo.

A seguir, são abordados os aspectos da demanda pelo transporte relacionados com cada um dos produtos do presente estudo, destacando-se os demandantes do serviço de transporte hidroviário e os demandantes de serviços alternativos.

\subsubsection{Soja em grão para exportação}

Verificando-se o comportamento das exportações de soja em grão, apresentado na Figura 5.5, nota-se que esse produto apresenta época de maior volume de exportações, e consequentemente de movimentação, das regiões produtoras até os portos. Nas exportações do ano de 1994, por exemplo, $91 \%$ do volume foi exportado nos meses de março a agosto.

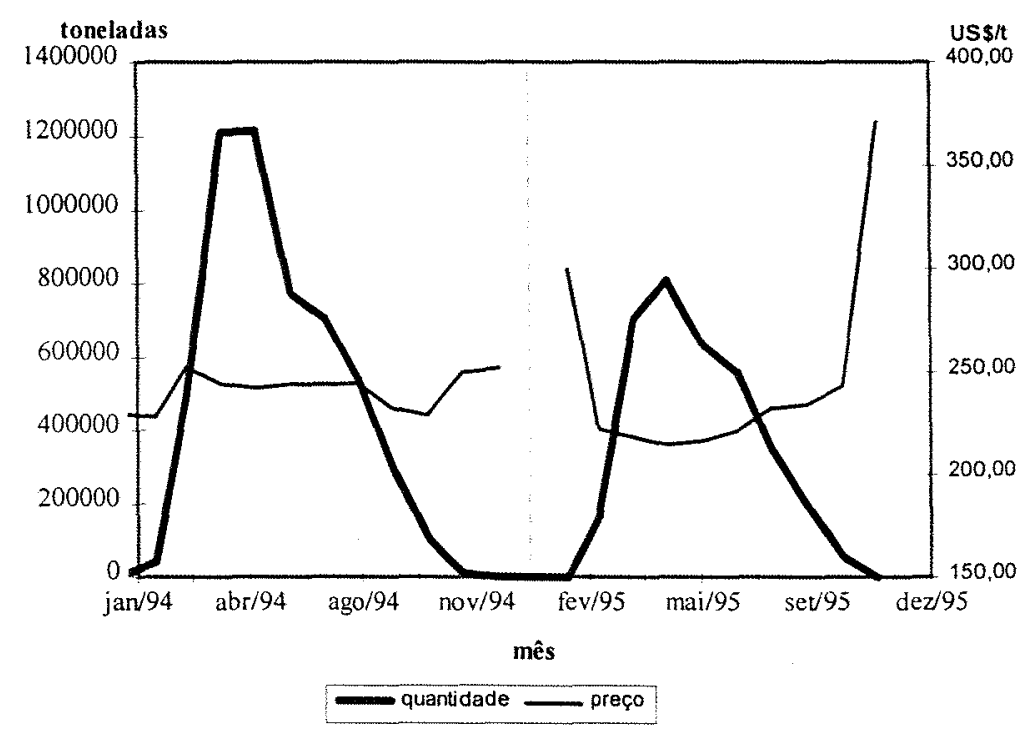

Figura 5.5 - Exportações brasileiras de soja em grão, quantidades (t) e preços (US\$/t), período de janeiro de 1994 a outubro de 1995 (Fonte: Banco Central do Brasil - BACEN, 1996)

As empresas que atuam na exportação de soja em grão devem estruturar a sua logística, de forma a estabelecer um fluxo de movimentação de cargas com destino ao porto de exportação. As operações envolvidas nesta atividade são: 
- aquisição da soja nas regiões produtoras;

- concentração do produto em armazéns próprios ou arrendados;

- escoamento do produto até o porto;

- armazenamento no porto e embarque nos navios transoceânicos.

Características como sazonalidade e necessidade de cumprimento de prazos de partida dos navios no porto estão associadas a um tipo específico de demanda pelo transporte.

Em função das particularidades da comercialização da soja em grão para exportação, surge o padrão de valorização dos atributos do serviço de transporte. As seguintes considerações sobre esses elementos podem ser feitas:

a) valor do frete - tendo em vista que as regiões produtoras de soja estão cada vez mais distanciadas dos portos, o peso do transporte é naturalmente elevado em comparação com outros países. Minimizando o custo de transporte, a empresa será capaz de concorrer melhor tanto na compra da soja como na venda no mercado externo.

b) tempo em trânsito - na Figura 5.5, percebe-se que o prę̧o pelo qual a soja foi exportada, apresenta relativa estabilidade, principalmente durante o período de maior volume exportado. Este fato pode ser explicado pelos mecanismos de "hedging", adotados pelas empresas, para evitar variações de preços durante o processo de movimentação. Desta forma, a questão do tempo em trânsito para empresas que operam com uma programação de longo prazo das exportações, pode ser considerado um aspecto não seletivo entre os serviços de transporte.

c) confiabilidade - atrasos inesperados, ou falta de confiança nos prazos de transporte, podem acarretar perdas advindas de gastos com estadia de navios e não cumprimento de contratos. Esses gastos, dada a dimensão do negócio da exportação, podem ser altamente significativos, fazendo com que a confiabilidade certamente seja avaliada na seleção dos serviços de transporte. 
O transporte hidroviário tem sido utilizado exclusivamente por duas empresas, para o escoamento da soja em grão das zonas produtoras do sul de Goiás até o porto de Santos. Essas empresas estão entre as quatro maiores exportadoras de soja em grão do país, apresentando uma estrutura completa de armazenagem junto às zonas produtoras e no porto de Santos, tendo optado pela internalização do serviço de transporte, incluída a modalidade hidroviária.

A alternativa hidroviária não é o único modo de transporte utilizado. De acordo com a origem da soja, essas empresas utilizam outras modalidades, entre elas a ferroviária e a rodoviária.

Segundo as empresas, com a internalização, aumentou-se a confiabilidade no sistema de transporte, através do controle total das operações. São evitados assim custos extras, advindos de eventualidades, ficando-se menos sujeito a variações do mercado de fretes ocasionadas pelo aumento da demanda na época de exportação. Fundamentalmente, o interesse das empresas está na minimização dos custos de transferência da soja em grão até o porto de Santos, de forma a maximizar o lucro da atividade de comercialização desse produto.

Por outro lado, internalizando o serviço de transporte hidroviário, essas empresas ficam sujeitas ao maior tempo em trânsito e à ociosidade gerada pela sazonalidade típica dessa atividade.

\subsubsection{Soja em grão como matéria-prima da indústria}

O principal destino da soja em grão é o mercado interno, para abastecer as indústrias produtoras de óleo de soja.

A empresa que demanda transporte visando o abastecimento da unidade industrial, objetiva adquirir a soja em grão nas regiões produtoras antes e durante a safra, em quantidades suficientes para abastecer a indústria o ano todo. Uma vez adquirido o produto, a empresa pode, de acordo com a sua logística: 
- transportar o produto do produtor diretamente para a indústria;

- armazenar o produto em armazéns próprios ou arrendados junto à região produtora e posteriormente transportá-lo para a indústria.

Essas duas operações logísticas são realizadas em conjunto, em função da estrutura disponivel. No que se refere à demanda por transporte, cada uma das opções logísticas está associada a um determinado padrão de exigência dos serviços de transporte.

De forma geral, os atributos do serviço de transporte para a atividade de transporte de soja em grão com destino à indústria, podem ser assim avaliados:

- valor do frete - quanto maior a distância da indústria às zonas produtoras, maior o custo de transporte da matéria-prima, o que influencia muito a competitividade da empresa como um todo;

- tempo em trânsito - variações de preço do produto e custo de oportunidade do capital durante o transporte são desconsiderados. Como o produto já pertence à empresa, que o adquiriu durante a safra, os custos mencionados não são acrescidos ao custo de transferência. Ao mesmo tempo, é observada a variação de preço ocasionada por perdas e danos;

- confiabilidade - as empresas normalmente trabalham com folga nos estoques, o que diminui muito o impacto de custos extras ocasionados por problemas inesperados com o transporte.

O transporte hidroviário tem sido utilizado por uma indústria de óleo de soja localizada em Osvaldo Cruz-SP, como uma das opções do escoamento da soja em grão produzida no sul de Goiás. Essa operação enquadra-se na opção logística de armazenamento junto à região de produção, com escoamento gradativo para a indústria durante o ano. Para essa situação, a possibilidade de operação com menor custo de transferência tem sido a principal motivação para o uso desse serviço. 
De acordo com a estratégia da empresa, está prevista a movimentação anual de $30 \%$ do volume proveniente da região do sul de Goiás, cerca de 50.000 t, pela alternativa multimodal que inclui a hidrovia.

Quanto à relação com o prestador do serviço, as empresas têm contratado o serviço no curto prazo, ou seja, para cada carga movimentada se realiza a negociação de valores de frete, tendo como referência limite o transporte rodoviário.

A alternativa hidroviária pressupõe a integração com outras modalidades, o que exige a contratação de serviços complementares de transporte. Isto tem funcionado de duas formas: ou a empresa se encarrega de contratar o serviço de transporte rodoviário complementar ou a transportadora hidroviária se encarrega dessa tarefa (serviço porta-àporta).

A utilização da alternativa hidroviária, na opção logística de transporte do produtor diretamente para a indústria, apresenta algumas dificuldades. A quantidade adquirida na zona produtora é muito maior que a disponibilidade da estrutura de armazenagem. Em função disso, um grande volume deve ser transportado durante o processo de colheita. Para tal, a modalidade de transporte deve ser ágil e deve ter uma capacidade de movimentação de grandes volumes em um curto espaço de tempo, o que não é característico do transporte hidroviário. Além disso, o grão oriundo do produtor não apresenta teor de umidade adequado para o transporte hidroviário, de acordo com 0 declarado pela empresa entrevistada.

Assim sendo, o principal problema destacado relaciona-se à pequena capacidade de movimentação de cargas, ocasionada tanto pela precária estrutura do terminal de descarga, quanto pela insuficiente disponibilidade de embarcações. 


\subsubsection{Farelo de soja}

As operações logísticas envolvidas na comercialização do farelo de soja dizem respeito a:

- armazenamento do produto na indústria;

- transporte do produto até o comprador no mercado interno;

- transporte do produto até o porto para exportação.

A atividade de exportação do farelo de soja apresenta algumas características particulares. O comportamento das exportações de farelo de soja, apresentado na Figura 5.6, mostra uma determinada sazonalidade, ainda que menos acentuada que aquela observada nas exportações da soja em grão.

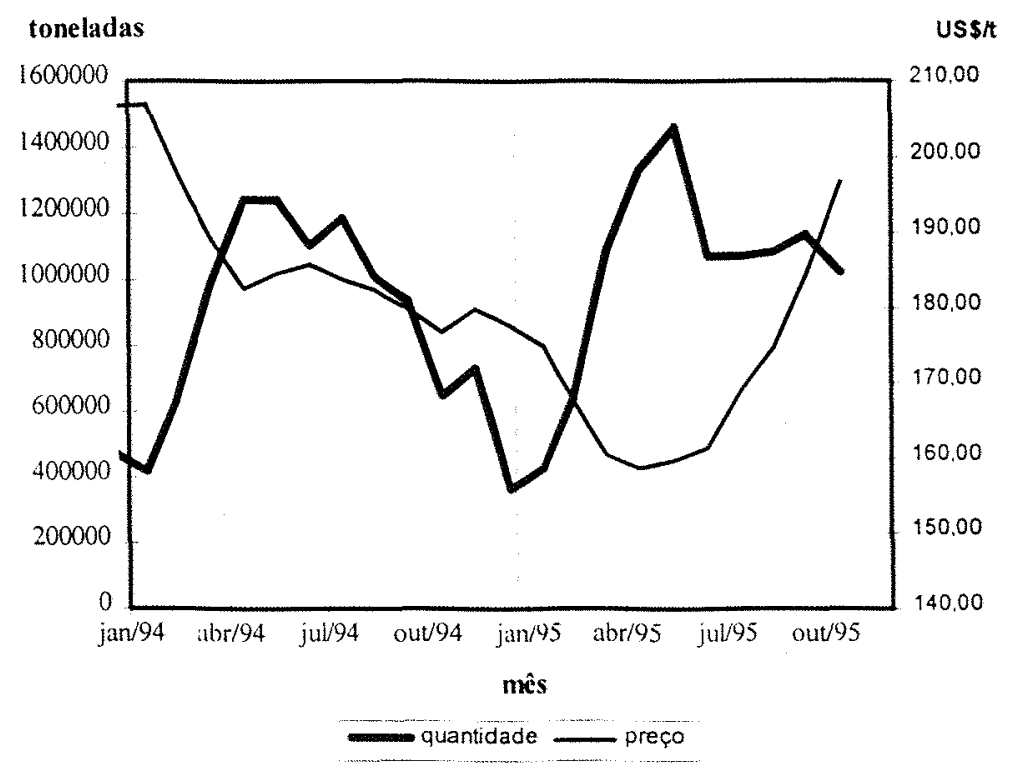

Figura 5.6 - Exportações brasileiras de farelo de soja, quantidades (t) e preços recebidos (US\$/t), período de janeiro de 1994 a outubro de 1995 (Fonte: BACEN, 1996).

Segundo as informações obtidas, pelo questionário aplicado em algumas indústrias de óleo de soja (que são as principais demandantes de transporte de farelo de 
soja), os seguintes atributos do serviço de transporte podem ser apresentados como importantes:

- prazo de entrega;

- seguro contra acidentes e roubo de carga;

- perdas e danos à carga;

- referência sobre o prestador do serviço;

- serviço oferecido porta-à-porta;

- pontualidade na entrega.

Percebe-se que os atributos destacados como importantes relacionam-se com a confiabilidade no serviço de transporte. Outros aspectos, tal como tempo em trânsito. ficaram em segundo plano em relação ao valor do frete e à confiabilidade. Também destacou-se a questão da variação do valor do frete associada com a indisponibilidade de veículos em determinadas épocas de maior demanda agregada.

Desta forma, para os demandantes de transporte de farelo de soja para exportação, os atributos apresentam as seguintes características:

a) valor do frete - a relevância do transporte na comercialização do farelo será tanto maior quanto maior a distancia da indústria em relação aos portos de exportação. Desta forma, indústrias localizadas nas regiões mais interiores tenderão a buscar alternativas de transporte mais baratas.

b) contiabilidade - da mesma forma como acontece na exportação da soja, serviços de transporte pouco confiaveis podem gerar o não cumprimento de cláusulas contratuais. que acarretam em custos significativos.

c) tempo em trânsito - como pode ser observado na Figura 5.7, o preço de exportação do farelo de soja apresenta variação mais acentuada que aquela observada para a soja em grão. Desta forma, a perda de valor do farelo de soja, durante o tempo em trânsito. não é uma possibilidade remota, o que leva a crer que essa variável possa ser um fator bastante considerado na seleção das alternativas de serviços de transporte, mesmo considerando o fato desse atributo ser menos importante que a confiabilidade. 
d) disponibilidade - a falta de disponibilidade para movimentar um determinado volume pode fazer com que a empresa perca partidas de navios, assim como a oportunidade de realização da renda a preços mais interessantes.

Indústrias de óleo de soja visitadas, localizadas no sul de Goiás e no Mato Grosso, basicamente movimentam farelo de soja com destino ao porto de Paranaguá via rodoviária ou rodo-ficroviária. Os volumes movimentados variam de $5.000 \mathrm{t} \mathrm{a} 25.000 \mathrm{t}$ ao mês, durante praticamente $o$ ano todo.

Por sua vez. a alternativa hidroviária do Tietê-Paraná tem sido utilizada para 0 transporte de farelo de soja por apenas uma empresa. As movimentações têm ocorrido da unidade industrial localizada em São Simão-GO, às margens da hidrovia TietêParaná, com destino ao porto de Santos.

Essa indústria de óleo de soja realizou todo o investimento, construindo a unidade industrial junto ao rio Paranaíba, com todas as instalações necessárias para realizar o carregamento do farelo nos comboios de transporte hidroviário. A produção diária de farelo de soja é da ordem de 1.200 t, ou seja, existe demanda contínua por transporte de carga em torno de $30.000 \mathrm{t} / \mathrm{mês}$.

O principal motivo desse investimento, segundo a empresa. é a exploração das vantagens do serviço hidroviário em função de seu menor preço em relação às outras alternativas de transporte disponíveis.

Ao contrário das empresas exportadoras de soja em grão, que internalizaram a atividade de transporte hidroviário, a empresa optou por contratar o serviço de terceiros. O serviço de transporte multimodal tem sido prestado de porta-à-porta, da indústria até os armazéns do porto de Santos.

Como o serviço é prestado por uma empresa que também transporta carga própria, em determinados periodos a disponibilidade de comboios diminui. comprometendo o escoamento do farelo. Este fato tem ocasionado problemas, inclusive de quebra de cliusulas contratuais. 
Como foi apresentado, o farelo possui dois destinos básicos de comercialização: o mercado interno e o mercado externo. No caso da comercialização do farelo de soja no mercado interno, a demanda pelos serviços de transporte difere em relação à demanda pelo transporte do farelo para exportação. As vendas para o mercado interno são realizadas para um grande número de compradores, que necessitam da entrega de pequenos volumes de farelo o mais rápido possível, em pontos dispersos.

O tamanho da carga, a dispersão da entrega e a necessidade de rapidez são fatores limitantes para a utilização do transporte hidroviário nesta operação de comercialização. O uso da alternativa hidroviária, mesmo para a empresa citada anteriormente, só seria possível se fossem montados pontos de distribuição junto às regiões demandantes, tal como a regiño de Laranjal Paulista-SP, próxima da hidrovia.

\section{2.+ Milho em grão}

As movimentações de milho em grão estão relacionadas com várias atividades econômicas, fundamentalmente realizadas no mercado interno, cujas características estão associadas a um determinado tipo de demanda pelo transporte desse grão.

Os consumidores de milho para a produção animal (empresas de ração. avicultura, suinocultura e pecuária) normalmente adquirem o produto de cerealistas ou atacadistas, que o entregam no local desejado. Sendo assim, os demandantes do transporte são os próprios cerealistas e atacadistas operantes no mercado.

Conforme informações obtidas pelo questionário enviado a três empresas consumidoras de milho, o prazo e pontualidade na entrega, assim como a disponibilidade para atender demandas não programadas com antecedência, foram fatores destacados como importantes para uma eficiente operação de transporte do milho.

As quantidades mensais demandadas de milho variam de acordo com o porte de cada empresa. observando valores entre 100 a 4.200 t. Nota-se que esses valores são bem inferiores aos volumes verificados nas movimentações de soja em grão e farelo de 
soja, e que as empresas nomalmente trabalham com estoques reduzidos e alta frequência de movimentação.

Desta forma. a modalidade que mais se enquadra no perfil de demanda apresentado acima é a rodoviaria, que trabalha com a movimentação de pequenos volumes à grande velocidade.

A alternativa hidroviária tem sido utilizada dentro do processo de comercialização do milho em grão com destino à produção animal por apenas uma empresa. A logística utilizada prevê a movimentação pela hidrovia, da região produtora do sul de Goiás até Santa Maria da Serra-SP. onde o milho é estocado e distribuído na região durante o ano todo. O transporte hidroviário é realizado pela própria empresa. que foi denominada no item 5.1 como empresa " $\mathrm{B}$ ".

As indústrias de processamento de milho (moagem seca e úmida), por outro lado. são grandes demandantes de milho em grão e normalmente o transporte ocorre sob a responsabilidade das mesmas. Neste caso, o padrão de demanda pelo transporte se assemelha ao observado para as indústrias de óleo de soja, que demandam o serviço de transporte para movimentar a soja em grão com destino à indústria. No entanto, nesse caso específico, a alternativa hidroviária estudada não tem sido utilizada.

\subsubsection{Considerações finais}

Segundos os dados levantados sobre a movimentações na hidrovia Tietê-Paraná. a soja em grão mostrou sazonalidade do volume movimentado mensalmente. Por outro lado, o milho em grão e o farelo de soja, apresentaram maior constância no volume mensal movimentado.

Os atuais demandantes do transporte hidroviário são basicamente empresas comercializadoras de soja c milho e indústrias produtoras de óleo de soja.

As empresas exportadoras de soja em grão. que optaram pelo uso da alternativa hidroviária, internalizaram essa atividade. Já as indústrias de óleo optaram pela 
contratação do transporte hidroviário de terceiros, atualmente trabalhando com contratos de curto prazo e utilizando a alternativa rodoviária como referencial limite de preço.

Dois tipos básicos de fluxos dos produtos estudados foram detectados, as movimentações de soja em grão e farelo de soja para a exportação, e as movimentações de soja em grão e milho em grão para o mercado interno. A soja em grão com destino ao mercado interno tem sido utilizada por apenas uma indústria de óleo de soja localizada no Estado de São Paulo. O milho em grão tem sido movimentado dentro de um esquema de comercialização centralizado por uma empresa, que vende no Estado de São Paulo o milho adquirido em Goiás. Pode-se dizer que o pequeno volume e a pulverização dos pontos de destino, são fatores limitantes ao uso da alternativa hidroviária na distribuição de milho em grão e farelo de soja para o mercado interno. principalmente para a produção animal

\subsection{Verificação da competitividade do transporte hidroviário}

Conforme a especificação apresentada no capítulo anterior, os custos de transferência por unidade de fluxo para o usuário, utilizados no modelo de rede. representam apenas a parcela referente ao custo direto associado ao pagamento do frete para o transportador. Os elementos associados com os custos indiretos, como por exemplo, os custos advindos do tempo em trânsito, não foram abordados quantitativamente.

O transporte hidroviário, por ser o elemento principal da análise, foi tratado do ponto de vista dos custos de produção do serviço de transporte, considerando-se o tipo e a intensidade de utilização do equipamento. Os valores adotados buscam oferecer uma variação entre a situação real enfrentada pelas empresas e a situação ideal considerada em projeto. Para o comboio simples, considerou-se o custo de US\$ 0,0195/t.km. referente a 66 viagens com $47,5 \%$ de carregamento e o custo de US\$ 0,0125/t.km. referente a 94 viagens com $62,5 \%$ de carregamento, respectivamente para a situação real

e para a siluação de projeto. Para o comboio duplo, considerou-se o custo de 
US $\$ 0,0147 / \mathrm{t} . \mathrm{km}$, referente a 50 viagens com $47,5 \%$ de carregamento e o custo de US $\$ 0,0092 / \mathrm{t} . \mathrm{km}$, referente a 72 viagens com $62,5 \%$ de carregamento, respectivamente para a situação real e para a situação de projeto.

Por outro lado, para a modalidade ferroviária, foi considerado o valor igual a US\$ $0,01925 / \mathrm{km}$, referente à média dos valores cobrados pela FEPASA ${ }^{20}$, no ano de 1995, para o transporte dos produtos estudados.

Os valores de frete rodoviário foram obtidos através da estimação de uma equação ajustada aos dados levantados por Soares \& Caixeta (1996), referentes aos fretes praticados em US\$/t no período de outubro de 1993 a outubro de 1996. A equação, os parâmetros estimados e os respectivos testes estatísticos podem ser vistos na Tabela 5.12.

Tabela 5.12 - Equação expressando a relação do valor do frete rodoviário (em US\$/t) com a distância $(\mathrm{km})$ para os produtos soja, milho e farelo de soja, transportados no período de outubro de 1993 a outubro de 1996,

\begin{tabular}{lcc}
\hline Equação & FRETE $=2,375982+0,032202 \times$ distância $-0,000004029 \times$ distância $^{2}$ \\
Teste $\mathbf{t}$ para os parâmetros & $3,552^{* *}$ & $21,992^{* *}$ \\
$\mathbf{n}^{0}$. de observaçôes & 687 \\
$\mathbf{R}^{2}$ & 0,862 \\
Teste F para a equação & $2133.316^{* *}$ \\
\hline
\end{tabular}

Dados primários obtidos de Soares \& Caixeta (1996)

** indica que o valor do teste é significativo a $1 \%$ de probabilidade

A utilização da equação apresentada na Tabela 5.12 está restrita às distâncias entre 55 e $1650 \mathrm{~km}$, amplitude esta igual à observada nos dados utilizados no ajustamento da equação. Não foram estimadas equações por produto, pois assumiu-se que não existe diferença no valor de frete cobrado entre eles. Os valores de frete estimados pela equação representam uma média praticada durante o ano, ou seja, não estão sendo consideradas as variações sazonais através da equação apresentada.

20 Valor calculado a partir de dados fornecidos pelo Departamento de Planejamento Empresarial da FEPASA S.A. 
Para a estruturação completa do modelo de rede, também considerou-se os custos terminais associados com o transbordo da mercadoria, em casos de utilização da alternativa multimodal. O valor adotado para tal foi de US\$1,50/t, valor observado em trabalhos como CESP (1995a), GEIPOT (1993) e Vitale (1980).

\subsubsection{Análise das rotas com destino ao porto de Santos}

As rotas com destino ao porto de Santos, com origem em São Simão (GO), Rio Verde (GO), Jatai (GO) e Rondonópolis (MT), relacionam-se com a movimentação de soja em grão e farelo de soja para exportação.

Foram consideradas várias alternativas de transporte para a ligação entre as origens e os destinos adotados. Tem-se, conforme o par de origem/destino, a alternativa unimodal rodoviária (rodo), e as multimodais hidro-ferroviária, hidro-rodoviária, rodoferroviária, rodo-hidro-ferroviária, rodo-hidro-rodoviária. Na Figura 5.7 podem ser visualizados esses detalhes, inclusive os pontos de transbordo para as alternativas multimodais. As distâncias associadas com cada alternativa de transporte são apresentadas na Tabela 1 do Anexo.

A Tabela 5.13 apresenta os resultados do processamento das rotas com destino ao porto de Santos, considerando os custos do transporte hidroviário para o comboio simples, os valores estimados pela equação (Tabela 5.12) para o frete rodoviário e o valor médio do frete cobrado em 1995 para a modalidade ferroviária. Constam desta tabela (e das demais que lhe forem similares, referentes aos resultados do processamento das rotas), a alternativa mais barata de ligação entre a origem e destino especificada, o 


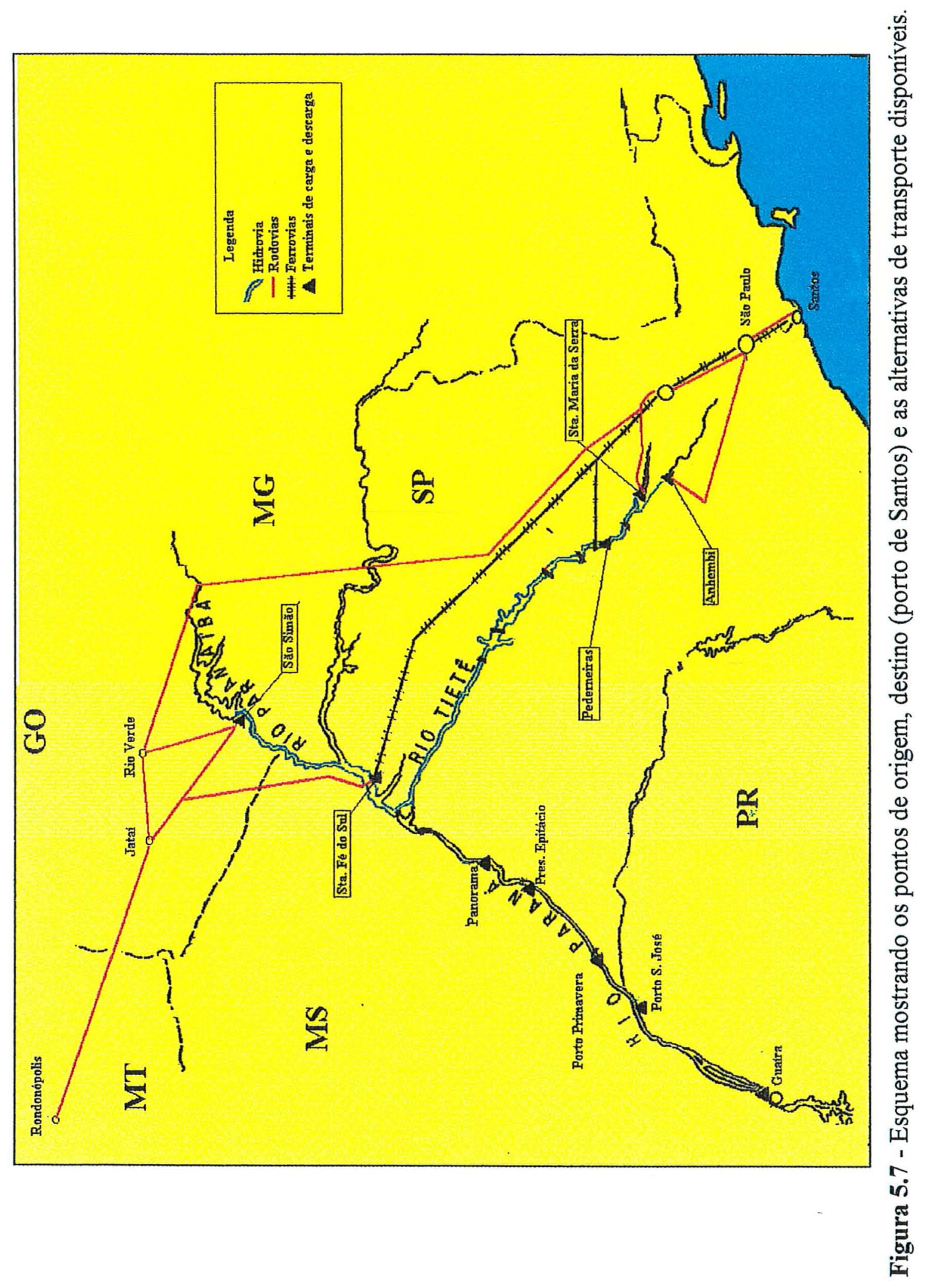


custo de transferência, a alternativa concorrente ${ }^{21}$, o seu custo de transferência e a diferença de custo entre a alternativa concorrente e a mais barata.

Tabela 5.13 - Resultados do processamento das rotas, considerando os custos associados ao comboio simples e destino Santos-SP.

\begin{tabular}{ccccccc}
\hline Origem & Destino & $\begin{array}{c}\text { Modalidade } \\
\text { escolhida }\end{array}$ & $\begin{array}{c}\text { Custo } \\
\text { transf. } \\
\text { US\$/t } \\
{[\mathbf{A}]}\end{array}$ & $\begin{array}{c}\text { Modalidade } \\
\text { alternativa }\end{array}$ & $\begin{array}{c}\text { Custo } \\
\text { transf. } \\
\text { US\$/t } \\
{[\mathbf{B}]}\end{array}$ & Diferença \\
\hline \multicolumn{7}{c}{ custo hidroviário US\$ 0,0125/t.km } \\
\hline São Simło & Santos & hidro-ferro & 20,55 & rodo & 28,34 & 7,79 \\
Rio Verde & Santos & rodo-hidro-ferro & 29,05 & rodo & 30,55 & 1,50 \\
Jataí & Santos & rodo-hidro-ferro & 30,42 & rodo-ferro & 32,70 & 2,28 \\
Rondonópolis & Santos & rodo & 40,80 & rodo-hidro-ferro & 40,88 & 0,08 \\
\hline \multicolumn{7}{c}{ custo hidroviário US\$ 0,0195/t.km } \\
\hline São Simão & Santos & hidro-ferro & 25,03 & rodo & 28,34 & 3,31 \\
Rio Verde & Santos & rodo & 30,55 & rodo-hidro-ferro & 33,53 & 2,98 \\
Jatai & Santos & rodo-ferro & 32,70 & rodo-hidro-ferro & 34,90 & 2,20 \\
Rondonópolis & Santos & rodo & 40,80 & rodo-hidro-ferro & 45,36 & 4,56 \\
\hline
\end{tabular}

Nota-se que, para a rota São Simão-Santos, a alternativa multimodal (hidro-ferro) foi vantajosa em relação ao transporte unimodal (rodo), para as duas situações de custo hidroviário. Por outro lado, a alternativa multimodal rodo-hidro-ferro, sofreu concorrència da unimodal rodo e multimodal rodo-ferro, quando se considerou o custo hidroviário (US\$ $\$ 0,0195 / \mathrm{t} . \mathrm{km}$ ), representativo de uma situação mais real das empresas de transporte hidroviário.

Quando se considerou a utilização do comboio duplo para o transporte hidroviário (Tabela 5.14), as alternativas multimodais hidro-ferro e rodo-hidro-ferro foram mais baratas, para o custo hidroviário igual a US $\$ 0,0092 / \mathrm{t} . \mathrm{km}$. Por outro lado, o aumento do custo hidroviário para US\$ $0.0147 / \mathrm{t} . \mathrm{km}$, tornou a alternativa rodo-hidroferro, das rotas Jataí-Santos e Rondonópolis-Santos, mais cara que as alternativas rodo e rodo-ferro. Para a rota Rio Verde-Santos, a alternativa rodo-hidro-ferro foi mais barata,

${ }^{21}$ Quando a alternativa multimodal que inclui a hidrovia for a mais barata, a concorrente será a alternativa rodo ou rodo-ferro, a que for de menor custo. Se a alternativa rodo ou rodo-ferro for a mais barata, a concorrente será a alternativa multimodal, que inclui a hidrovia, e for de menor custo. 
que o concorrente imediato, nas duas situações de custo hidroviário. Este fato pode ser explicado pela menor participação da modalidade rodoviária na alternativa multimodal rodo-hidro-ferro da rota Rio Verde-Santos que das rotas Jataí-Santos e RondonópolisSantos (ver Tabela 1 do Anexo).

Tabela 5.14 - Resultados do processamento das rotas, considerando os custos associados ao comboio duplo e destino Santos-SP.

\begin{tabular}{ccccccc}
\hline Origem & Destino & $\begin{array}{c}\text { Modalidade } \\
\text { escolhida }\end{array}$ & $\begin{array}{c}\text { Custo } \\
\text { transf. } \\
\text { US\$/t } \\
{[\mathbf{A}]}\end{array}$ & $\begin{array}{c}\text { Modalidade } \\
\text { alternativa }\end{array}$ & $\begin{array}{c}\text { Custo } \\
\text { transf. } \\
\text { US\$/t } \\
\text { [B] }\end{array}$ & Diferença \\
\hline \multicolumn{7}{c}{ custo hidroviário US\$ 0,0092/t.km } \\
\hline São Simão & Santos & hidro-ferro & 18,44 & rodo & 28,34 & 9,91 \\
Rio Verde & Santos & rodo-hidro-ferro & 26,94 & rodo & 30,55 & 3,61 \\
Jataí & Santos & rodo-hidro-ferro & 28,31 & rodo-ferro & 32,71 & 4,40 \\
Rondonópolis & Santos & rodo-hidro-ferro & 38,77 & rodo & 40.80 & 2,03 \\
\hline \multicolumn{7}{c}{ custo hidroviário US\$ 0,0147/t.km } \\
\hline São Simão & Santos & hidro-ferro & 21,96 & rodo \\
Rio Verde & Santos & rodo-hidro-ferro & 30,45 & rodo & 28,34 & 6,39 \\
Jataí & Santos & rodo-ferro & 31,60 & rodo-hidro-ferro & 31,83 & 0,23 \\
Rondonópolis & Santos & rodo & 40,80 & rodo-hidro-ferro & 42,29 & 1,49 \\
\hline
\end{tabular}

\subsubsection{Análise das rotas com destino a algumas cidades do Estado de São Paulo}

Nessa análise optou-se pela fixação do local de origem em dois pontos, um que implica na necessidade de uso da modalidade rodoviária para a conexão com a hidrovia e o outro que não necessiti da referida conexão. Foram assim consideradas como origem as cidades de Rio Verde (GO) e São Simão (GO), e como destino as seguintes cidades do Estado de São Paulo: Osvaldo Cruz, Ourinhos, Mairinque, Campinas, Tietè, Descalvado e Mogi-Guaçu. Essas cidades foram escolhidas por serem demandantes de soja, milho e lärelo de soja, para suprir a produção das indústrias produtoras de óleo e as granjas de avicultura e suinocultura. Ainda considerou-se nessa escolha a distribuição 
geográfica das cidades, segundo um posicionamento circundante aos terminais de transbordo hidroviário de Pederneiras, Santa Maria da Scrra e Anhembi.

$\mathrm{Na}$ Figura 5.8 pode-se visualizar os detalhes da rede de transporte considerada e o posicionamento do ponto de origem e do ponto de destino. Cabe destacar que, de acordo com a posição do ponto de destino, as alternativas de transporte se modificam. Por exemplo. a rota Rio Verde-Campinas possui as alternativas unimodal rodoviária e as multimodais rodo-ferro, rodo-hidro-ferro e rodo-hidro-rodo. Por outro lado, a rota Rio Verde-Descalvado possui a alternativa unimodal rodoviária e a multimodal rodo-hidrorodo.

As distâncias associadas com cada alternativa de transporte podem ser visualizadas na Tabela 2 do Anexo. Deve-se salientar que o uso do percurso entre o terminal de Sĩo Simão (GO) e os terminais de Panorama e Presidente Epitácio foi hipotético pois a eclusa de Jupiá não se encontra em funcionamento.

Considcrando os custos do comboio simples (US\$0,0125/t.km e US\$ 0,0195/t.km), o valor médio estimado pela equação para o frete rodoviário e o valor médio do frete ferroviário para 1995, tem-se os resultados apresentados na Tabela 5.15.

Percebc-se da Tabela 5.15 que a alternativa unimodal (rodo) compete com as alternativas multimodais rodo-hidro-ferro e rodo-hidro-rodo, de acordo com a rota considerada, para a situação de custo hidroviário igual a US\$ 0,0125/t.km. Por outro lado, ao se considerar o custo hidroviário (US\$ 0,0195/t.km) mais proximo da realidade das empresas que estão operando com o transporte hidroviário, a alternativa unimodal rodoviária supcra em custo as multimodais rodo-hidro-ferro e rodo-hidro-rodo em todas as rotas.

Para o caso dos custos hidroviários referentes ao comboio duplo, os resultados do processamento das rotas podem ser visualizados na Tabela 5.16. 


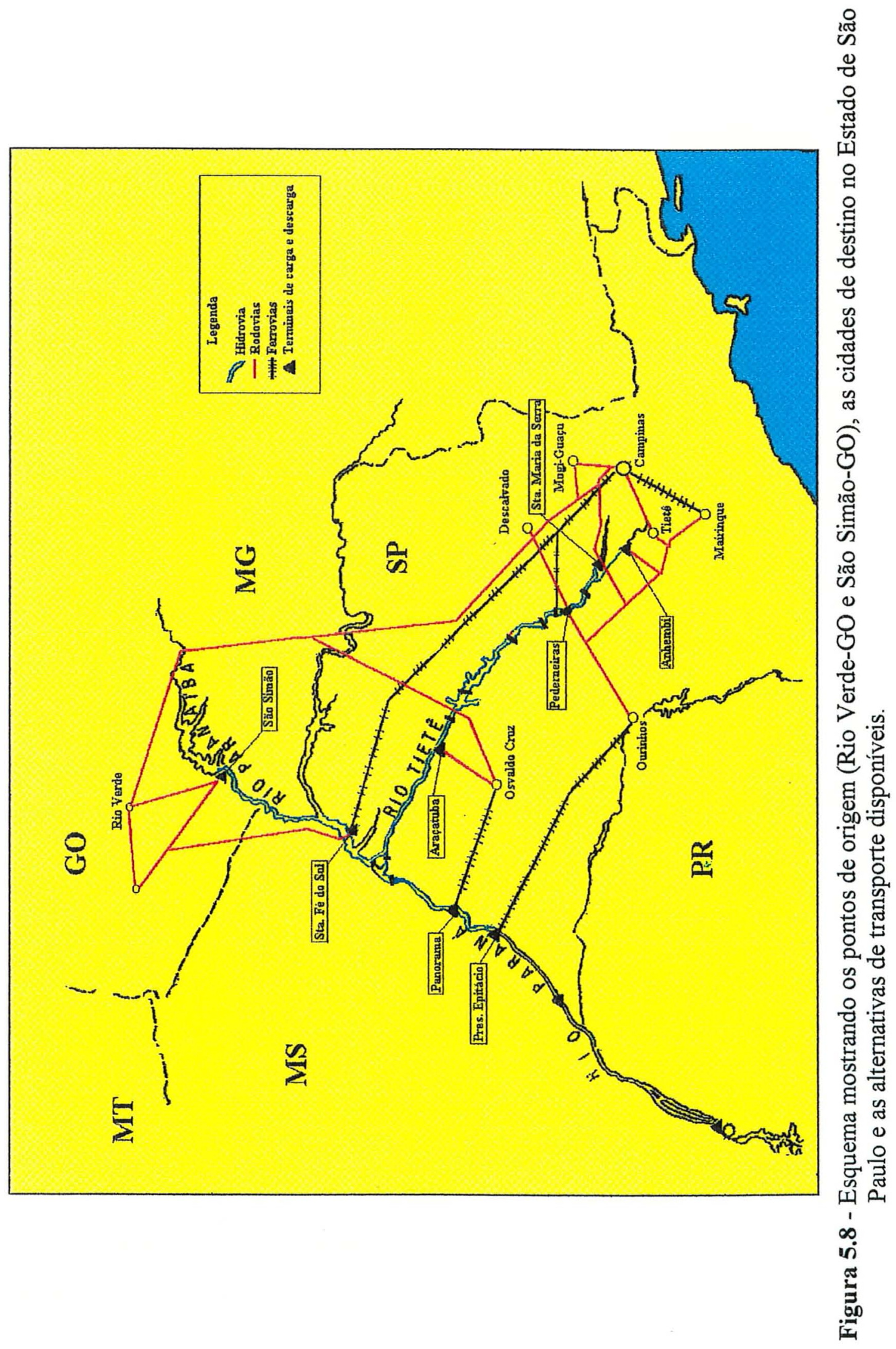


Tabela 5.15 - Resultados do processamento das rotas, considerando os custos associados ao comboio simples e origem Rio Verde-GO.

\begin{tabular}{|c|c|c|c|c|c|c|}
\hline Origem & Destino & $\begin{array}{l}\text { Modalidade } \\
\text { escolhida }\end{array}$ & $\begin{array}{c}\text { Custo } \\
\text { transf. US } \$ / t \\
{[A]}\end{array}$ & $\begin{array}{l}\text { Modalidade } \\
\text { alternativa }\end{array}$ & $\begin{array}{c}\text { Custo } \\
\text { transf. } \\
\text { US\$/t } \\
|B|\end{array}$ & $\begin{array}{c}\text { Diferença } \\
\mid \text { B-A| }\end{array}$ \\
\hline \multicolumn{7}{|c|}{ US\$ $0.0125 /$ t.km } \\
\hline Rio Verde & Osvaldo Cruz & rodo & 18,03 & rodo-hidro-ferro & 19.08 & 1,05 \\
\hline Rio Verde & Descalvado & rodo & 22.94 & rodo-hidro-rodo & 26.61 & 3,67 \\
\hline Rio Verde & Campinas & rodo-hidro-ferro & 23.87 & rodo & 27.09 & 3,22 \\
\hline Rio Verde & Tietê & rodo & 24.84 & rodo-hidro-rodo & 26.26 & 1,42 \\
\hline Rio Vorde & Ourinhos & rodo-hidro-ferro & 24,92 & rodo & 28,99 & 4,07 \\
\hline Rio Verde & Mogi Guaçu & rodo-hidro-rodo & 26,58 & rodo & 27.04 & 0,46 \\
\hline Rio Verde & Mairinque & rodo-hidro-ferro & 26.82 & rodo & 29.33 & 2,51 \\
\hline \multicolumn{7}{|c|}{ US\$ $0,0195 / \mathrm{t} . \mathrm{km}$} \\
\hline Rio Verde & Osvaldo Cruz & rodo & 18,03 & rodo-hidro-ferro & 21.94 & 3,91 \\
\hline Rio Verde & Descalvado & rodo & 22,94 & rodo-hidro-rodo & 31.22 & 8,28 \\
\hline Rio Verde & Tietê & rodo & 24,84 & rodo-hidro-rodo & 31.57 & 6,73 \\
\hline Rio Verde & Mogi Guaçu & rodo & 27,04 & rodo-hidro-rodo & 31.19 & 4,15 \\
\hline Rio Verde & Campinas & rodo & 27,09 & rodo-hidro-ferro & 28.35 & 1,26 \\
\hline Rio Verde & Ourinhos & rodo & 28,23 & rodo-hidro-ferro & 31.16 & 2,93 \\
\hline Rio Verde & Mairinque & rodo & 29,33 & rodo-hidro-ferro & 31.30 & 1,97 \\
\hline
\end{tabular}

Tabela 5.16 - Resultados do processamento das rotas, considerando os custos associados ao comboio duplo e origem Rio Verde-GO.

\begin{tabular}{|c|c|c|c|c|c|c|}
\hline Origem & Destino & $\begin{array}{l}\text { Modalidade } \\
\text { escolhida }\end{array}$ & $\begin{array}{c}\text { Custo } \\
\text { transf. } \\
\text { US\$/t } \\
|A| \\
\end{array}$ & $\begin{array}{l}\text { Modalidade } \\
\text { alternativa }\end{array}$ & $\begin{array}{c}\text { Custo } \\
\text { transf. } \\
\text { US\$/t } \\
{[B \mid} \\
\end{array}$ & $\begin{array}{c}\text { Diferença } \\
\text { [B-A] }\end{array}$ \\
\hline \multicolumn{7}{|c|}{ US\$ $0,0092 / \mathrm{t} . \mathrm{km}$} \\
\hline Rio Verde & Osvaldo Cruz & rodo-hidro-ferro & 17,72 & rodo & 18.03 & 0,31 \\
\hline Rio Vorde & Ourinhos & rodo-hidro-ferro & 23,36 & rodo & 28,99 & 5,63 \\
\hline Rio Verde & Mairinque & rodo-hidro-ferro & 24,71 & rodo & 29,33 & 4,62 \\
\hline Rio Verde & Campinas & rodo-hidro-ferro & 21,76 & rodo & 27,10 & 5,34 \\
\hline Rio Verde & Tietề & rodo-hidro-rodo & 23,75 & rodo & 24,84 & 1,09 \\
\hline Rio Verde & Descalvado & rodo & 22,94 & rodo-hidro-rodo & 24,43 & 1,49 \\
\hline Rio Virde & Mogi Guaçu & rodo-hidro-rodo & 24,96 & rodo & 27,03 & 2,07 \\
\hline \multicolumn{7}{|c|}{ US\$ $0,0147 /$ t.km } \\
\hline Rio Vurde & Osvaldo Cruz & rodo & 18,03 & rodo-hidro-ferro & 19,98 & 1,95 \\
\hline Rio Virde & Ourinhos & rodo-hidro-ferro & 25,96 & rodo & 28.99 & 3,03 \\
\hline Rio Verde & Mairinque & rodo-hidro-ferro & 28.23 & rodo & 29,33 & 1,10 \\
\hline Rio Verde & Campinas & rodo-hidro-ferro & 25.28 & rodo & 27,09 & 1,81 \\
\hline Rio Verde & Tietê & rodo & 24,84 & rodo-hidro-rodo & 27,93 & 3,09 \\
\hline Rio Verde & Descalvado & rodo & 22.94 & rodo-hidro-rodo & 28.06 & 5,12 \\
\hline Rio Vorde & Mogi Guaçu & rodo & 27.04 & rodo-hidro-rodo & 28,03 & 0,99 \\
\hline
\end{tabular}


Nota-se que a superioridade da alternativa multimodal (rodo-hidro-ferro) em rclação à unimodal rodoviária. ocorre em todos as casos para o custo hidroviário de US\$ $\$, 0092 / \mathrm{t} . \mathrm{km}$. No entanto, com o aumento do custo hidroviário para US\$ $0,0147 / \mathrm{t} . \mathrm{km}$, a superioridade cai especialmente no caso da alternativa multimodal rodo-hidro-rodo, não se observando vantagem competitiva dessa alternativa com relação a alternativa unimodal rodo. A alternativa rodo-hidro-ferro, apresentou um potencial competitivo melhor. superando a alternativa unimodal rodo em várias rotas, para as duas situações de custo hidroviário.

As rotas com origem em São Simão $(\mathrm{GO})$ tem os resultados apresentados nas Tabelas 5.17 e 5.18 . Nota-se na Tabela 5.17 que para a rota São Simão-Descalvado, a alternativa rodo foi mais vantajosa para as duas situações de custo hidroviário. O posicionamento geográfico de Descalvado favorece a alternativa rodoviária, que apresenta distîncia menor que a alternativa multimodal (ver Tabela 2 do Anexo). Para os demais casos, notou-se que a alternativa multimodal foi bastante competitiva, sendo a hidro-ferro mais que a hidro-rodo. Por outro lado, na Tabela 5.18 percebe-se a nítida vantagem das alternativas multimodais, em função do menor custo hidroviário referente à utilização do comboio duplo.

Ressalta-se que a origem em São Simão $(G O)$ é restritiva quanto aos produtos, uma vez que, o farelo de soja é o único produzido junto à hidrovia. Deve-se ainda considerar que a movimentação de farelo de soja, para o abastecimento interno, destinase à produção animal, que movimenta volumes pequenos, com maior frequência e necessidade de entrega rípida. Sendo assim. a utilização dessas rotas seria viável se a comercializaçilo e o transporte fossem geridos por uma empresa, que utilizasse o transporte hidroviário para deslocar grandes volumes até mais perto dos centros consumidores c posteriormente o distribuisse de forma fragmentada. 
Tabela 5.17 - Resultados do processamento das rotas, considerando os custos associados ao comboio simples e origem São Simão-GO.

\begin{tabular}{|c|c|c|c|c|c|c|}
\hline Origem & Destino & $\begin{array}{l}\text { Modalidade } \\
\text { escolhida }\end{array}$ & $\begin{array}{c}\text { Custo } \\
\text { transf. } \\
\text { US\$/t } \\
|A| \\
\end{array}$ & $\begin{array}{l}\text { Modalidade } \\
\text { alternativa }\end{array}$ & $\begin{array}{c}\text { Custo } \\
\text { transf. } \\
\text { US\$/t } \\
{[B]}\end{array}$ & $\begin{array}{c}\text { Diferença } \\
\qquad|\mathrm{B}-\mathrm{A}|\end{array}$ \\
\hline \multicolumn{7}{|c|}{ US\$ $0.0125 / \mathrm{t} . \mathrm{km}$} \\
\hline São Simão & Osvaldo Cruz & hidro-ferro & 10,58 & rodo & 12,42 & 1.84 \\
\hline São Simão & Ourinhos & hidro-ferro & 16.42 & rodo & 24,03 & 7.61 \\
\hline Săo Simão & Mairinque & hidro-ferro & 18.32 & rodo & 24,39 & 6.07 \\
\hline São Simão & Campinas & hidro-ferro & 15.37 & rodo & 22,01 & 6.64 \\
\hline São Simão & Tietê & hidro-rodo & 17,76 & rodo & 19.62 & 1.86 \\
\hline São Simào & Descalvado & rodo & 17.61 & hidro-rodo & 17,74 & 0.13 \\
\hline São Simão & Mogi Guaçu & hidro-rodo & 18.84 & rodo & 21,96 & 3.12 \\
\hline \multicolumn{7}{|c|}{ US\$ $0,0195 / \mathrm{t} . \mathrm{km}$} \\
\hline São Simão & Osvaldo Cruz & rodo & 12,42 & hidro-ferro & 13,45 & 1.03 \\
\hline São Simão & Ourinhos & hidro-ferro & 19.73 & rodo & 24,03 & +.30 \\
\hline São Simão & Mairinque & hidro-ferro & 22,80 & rodo & 24,39 & 1.59 \\
\hline São Simão & Campinas & hidro-ferro & 19,85 & rodo & 22,01 & 2,16 \\
\hline São Simão & Tietê & rodo & 19,62 & hidro-rodo & 23.07 & 3.45 \\
\hline São Simão & Descalvado & rodo & 17,61 & hidro-rodo & 22,22 & 4.61 \\
\hline São Simão & Mogi Guaçu & rodo & 21.96 & hidro-rodo & 23,88 & 1.92 \\
\hline
\end{tabular}

Tabela 5.18 - Resultados do processamento das rotas, considerando os custos associados ao comboio duplo e origem São Simão-GO.

\begin{tabular}{|c|c|c|c|c|c|c|}
\hline Origem & Destino & $\begin{array}{l}\text { Modalidade } \\
\text { escolhida }\end{array}$ & $\begin{array}{c}\text { Custo } \\
\text { transf. } \\
\text { US } \$ / \mathrm{t} \\
|\mathrm{A}|\end{array}$ & $\begin{array}{l}\text { Modalidade } \\
\text { alternativa }\end{array}$ & $\begin{array}{c}\text { Custo } \\
\text { transf. } \\
\text { US\$/t } \\
{[B]}\end{array}$ & $\begin{array}{c}\text { Diferença } \\
|\mathrm{B}-\mathrm{A}|\end{array}$ \\
\hline \multicolumn{7}{|c|}{ US\$ $0.0092 / \mathrm{t} . \mathrm{km}$} \\
\hline São Simão & Osvaldo Cruz & hidro-ferro & 9,22 & rodo & 11,66 & 3,20 \\
\hline Săo Simão & Ourinhos & hidro-ferro & 14,86 & rodo & 24,03 & 9,17 \\
\hline São Simão & Mairinque & hidro-ferro & 16,20 & rodo & 24,39 & 8,19 \\
\hline São Simão & Campinas & hidro-ferro & 13,25 & rodo & 22,01 & 8.76 \\
\hline São Simão & Tietề & hidro-rodo & 15,25 & rodo & 19,62 & 4,37 \\
\hline São Simão & Descalvado & hidro-rodo & 15,62 & rodo & 17,61 & 1.99 \\
\hline São Simào & Mogi Guaçu & hidro-rodo & 16,46 & rodo & 21,96 & 5.50 \\
\hline \multicolumn{7}{|c|}{ US\$ $0,01+7 / \mathrm{t} . \mathrm{km}$} \\
\hline Săo Simão & Osvaldo Cruz & hidro-ferro & 11,48 & rodo & 12,42 & 0.94 \\
\hline São Simão & Ourinhos & hidro-ferro & 17,46 & rodo & 24,03 & 6,57 \\
\hline Sđ̃o Simão & Mairinque & hidro-ferro & 19.72 & rodo & 24,39 & 4,67 \\
\hline São Simão & Campinas & hidro-ferro & 16,77 & rodo & 22,01 & 5.24 \\
\hline São Simão & Tietê & hidro-rodo & 19.63 & rodo & 19.82 & 0.19 \\
\hline São Simão & Descalvado & rodo & 17,61 & hidro-rodo & 19,14 & 1,53 \\
\hline São Simão & Mogi Guaçu & hidro-rodo & 20,42 & rodo & 21.96 & 1,54 \\
\hline
\end{tabular}




\subsubsection{Considerações finais}

Observou-se que a alternativa multimodal, que inclui a passagem pela hidrovia, sofreu a concorrência do transporte rodoviário em intensidade variável, de acordo com ciada rota e condição de custo do transporte hidroviário.

Para as rotas com destino ao porto de Santos, a diferença média da alternativa multimodal, que incluiu a hidrovia, com relação à alternativa unimodal rodoviária pode scr visualizada na Tabela 5.19.

Tabela 5.19 - Diferença percentual média do custo das alternativas multimodais com relaçio à alternativa rodoviária, para as condições consideradas do transporte hidroviário e rotas com destino a Santos.

\begin{tabular}{cccc|rrrr}
\hline \multicolumn{3}{c|}{ Condição hidroviária } & \multicolumn{4}{c}{ Diferença (\%) } \\
$\begin{array}{c}\text { Tipo } \\
\text { comboio }\end{array}$ & $\begin{array}{c}\text { no. } \\
\text { viagens }\end{array}$ & $\begin{array}{c}\text { \% } \\
\text { calternativa multimodal }\end{array}$ & $\begin{array}{c}\text { custo } \\
\text { hidroviário } \\
\text { US\$/t.km }\end{array}$ & h-f & h-r & r-h-f & r-h-r \\
\hline duplo & 72 & 62,5 & 0.0092 & $-34,97$ & $-23,34$ & $-11,26$ & $-1,75$ \\
simples & 94 & 62,5 & 0.0125 & $-27,49$ & $-14,71$ & $-1,06$ & 9,40 \\
duplo & 50 & 47.5 & 0.0147 & $-22,55$ & $-8,98$ & $-1,69$ & 9,41 \\
simples & 66 & 47.5 & 0.0195 & $-11,68$ & 3,55 & 6,10 & 19,49 \\
\hline
\end{tabular}

onde: $r$ - rodovia; $h$ - hidrovia e $t$ - ferrovia

$\mathrm{Da}$ Tabela 5.19 percebe-se que as maiores diferenças negativas, que correspondem a uma op̧̧ĩo mais econômica que o transporte rodoviário direto, estão associadas com as alternativas multimodais (h-f e $\mathbf{h}-\mathbf{r}$ ) que não incluem a opção rodoviária na coleta da carga. Ressalte-se que a origem junto à hidrovia, aplica-se apenas ao farelo de soja. Para o caso de soja em grão e milho em grão, necessariamente, deve existir a conexão rodoviária na alternativa multimodal. No caso da alternativa multimodal incluir a modlilidade rodoviária. a alternativa $\mathbf{r}$-h-f se apresentou melhor que 
a $\mathbf{r}$-h-r. ou seja, a inclusão da modalidade todoviária nas duas pontas do transporte multimodal reduziu a sua competitividade.

Ainda na Tabela 5.19, pode-se observar a influência da condição hidroviária sobre a competitividade das alternativas multimodais. Observa-se que o comboio duplo foi o que apresentou maior economia, quando operado em condição de projeto (72 viagens e $62,5 \%$ de carregamento). Para a condição mais próxima da realidade (50 viagens e $47,5 \%$ de carregamento), o valor se reduz até se tornar positivo (mais caro que o rodoviário). Por outro lado, o mesmo comportamento é observado para o comboio simples, destacando-se que na condição mais próxima do real (66 viagens e 47,5\% de carregamento), a alternativa multimodal apresenta-se mais cara que a rodoviária, com exceção da $\mathbf{h}-\mathbf{f}$.

Para o caso das rotas com destino a cidades do Estado de São Paulo, a diferença obtida pelo uso da alternativa multimodal com relação à unimodal rodoviária pode ser visualizada na Tabela 5.20 .

Tabela 5.20 - Diferença percentual média do custo das alternativas multimodais com relação à alternativa rodoviúria, para as condições consideradas do transporte hidroviário e rotas com destino a algumas cidades do Estado de São Paulo.

\begin{tabular}{|c|c|c|c|c|c|c|c|}
\hline \multicolumn{4}{|c|}{ Condição hidroviária } & \multicolumn{4}{|c|}{$\begin{array}{l}\text { Diferença (\%) } \\
\text { alternativa multimodal }\end{array}$} \\
\hline $\begin{array}{l}\text { Tipo } \\
\text { comboio }\end{array}$ & $\begin{array}{c}\text { no. } \\
\text { viagens }\end{array}$ & $\begin{array}{c}\% \\
\text { carregamento }\end{array}$ & $\begin{array}{c}\text { custo } \\
\text { hidroviario } \\
\text { US\$/t.km }\end{array}$ & h-f & $\begin{array}{l}\text { rnativa } \\
\text { h-r }\end{array}$ & & r-h-r \\
\hline duplo & 72 & 62,5 & 0.0092 & $-29,94$ & $-9,92$ & $-14,16$ & 1,25 \\
\hline simples & 94 & 62.5 & 0.0125 & $-25,55$ & 0,33 & $-7,17$ & 10,49 \\
\hline duplo & 50 & 47,5 & 0.0147 & $-24,02$ & 7,58 & $-2,54$ & 15,94 \\
\hline simples & 66 & 47,5 & 0.0195 & $-6,48$ & 24,72 & 7,62 & 28,75 \\
\hline
\end{tabular}

onde: $\mathrm{r}$ - rodovia; $\mathrm{h}$ - hidrovia e $\mathrm{f}$ - ferrovia

Percebe-se, a partir da Tabela 5.20, que as alternativas h-f e $\mathbf{r}$-h-f apresentaram diferenças de $-29,94 \%$ a $7,62 \%$, ao passo que as $\mathbf{h}-\mathbf{r}$ e $\mathbf{r}$-h-r atingiram valores entre $-9,92 \%$ e $28.75 \%$. Desta forma, fica evidente a menor competitividade das alternativas 
que incluiram o transporte rodoviário, o que representa um fator altamente restritivo para o uso dessa alternativa multimodal frente a alternativa unimodal rodoviária. Também lica clara a influência da condição de operação hidroviária sobre a diferença com relação ao transporte rodoviário direto, e consequentemente sobre a competitividade do transporte multimodal. Para o comboio simples, na alternativa $\mathbf{h}-\mathbf{f}$, a diferença variou de $-25.55 \%$ para $-6.48 \%$, respectivamente para a condição de projeto e para a mais próxima da realidade.

As variações da diferença percentual do transporte multimodal com relação ao unimodal rodoviário podem também ser vistas segundo os terminais hidroviários de desembarque (Tabela 5.21). Os terminais de Anhembi, Araçatuba e Santa Maria da Serra. que possuem transbordo exclusivo para a modalidade rodoviária, apresentaram diferenças negativas apenas na condição hidroviária prevista em projeto (72 viagens e $62,5 \%$ de carregamento) para o comboio duplo. Por outro lado, os terminais de Panorama, Presidente Epitácio e Pederneiras, que possuem conexão ferroviária, apresentaram diferenças negativas, indicando maior economia com relação à alternativa unimodal rodoviária.

Tabela 5.21 - Diferença percentual média do custo das alternativas multimodais com relação à altemativa rodoviária, segundo os terminais hidroviários de descarga.

\begin{tabular}{|c|c|c|c|c|c|c|c|c|c|}
\hline \multicolumn{4}{|c|}{ Condição hidroviária } & \multicolumn{6}{|c|}{ Terminal } \\
\hline $\begin{array}{c}\text { lipo } \\
\text { comboio }\end{array}$ & $\begin{array}{l}\text { no. } \\
\text { via- } \\
\text { gens }\end{array}$ & $\begin{array}{c}\% \\
\text { carre } \\
\text { gamento }\end{array}$ & $\begin{array}{l}\text { custo } \\
\text { hidrov } \\
\text { ussurkm }\end{array}$ & Tuhembi & $\begin{array}{l}\text { Araç- } \\
\text { tuba }\end{array}$ & $\begin{array}{l}\text { Santa } \\
\text { Maria } \\
\text { /diferen }\end{array}$ & $\begin{array}{l}\text { Pano- } \\
\text { rama } \\
(\%) \mid\end{array}$ & $\begin{array}{c}\text { Pres. } \\
\text { Epitácio }\end{array}$ & $\begin{array}{l}\text { Peder- } \\
\text { neiras }\end{array}$ \\
\hline duplo & 72 & 62.5 & 0.0092 & $-2,37$ & 10,03 & $-6,92$ & $-4,96$ & $-28,79$ & $-13,74$ \\
\hline simples & 94 & 62.5 & 0.0125 & 9,12 & 10.21 & 3,99 & $-4,81$ & $-22,85$ & $-5,77$ \\
\hline duplo & 50 & 47.5 & 0.0147 & 15,80 & 8,10 & 10,23 & $-7,48$ & $-18,90$ & 1,49 \\
\hline simples & 66 & 47.5 & 0.0195 & 31,50 & 26.59 & 25,79 & 15.02 & $-10,26$ & 13,61 \\
\hline
\end{tabular}


A diferença de custo da alternativa multimodal com relação à alternativa unimodal rodoviária. reflete o efeito agregado de uma série de elementos associados ao transporte multimodal; dentre eles a variação da distância de percurso da alternativa multimodal com relação a alternativa unimodal rodoviária, a váriação do custo hidroviário e o custo de transbordo. O efeito da variação do custo hidroviário já foi apresentado de várias formas, nas tabelas anteriores.

No caso do custo de transbordo. o impacto da variação dessa variável considerando os valores de US\$1,0/t, US\$ $1.5 /$ t e US\$2,0/t, pode ser visualizado nos gráficos de "Box Plot" apresentados nas Figuras 5.9 e 5.10.

Observando-se a Figura 5.9 nota-se que a variação do custo de transbordo não foi suficiente para deslocar a média ${ }^{22}$ abaixo de zero, quando a diferença do custo da alternativa multimodal com relação a unimodal rodoviária seria negativa, indicando o menor custo da multimodal. Por outro lado, a variação do custo de transbordo para US $\$ 2,00$, deslocou a média da alternativa multimodal $\mathbf{r}$-h-f para cima de zero, como pode ser observado na Figura 5.10. As demais alternativas multimodais não apresentaram variação para cima ou para baixo de zero, dada a variação do custo de transbordo. A alternativa h-f mateve a tendência de ser mais barata que a unimodal rodoviária (valores da diferença percentual negativos) e as alternativas $\mathbf{r}-\mathbf{h}-\mathbf{r}$ e h-r continuaram apresentando maior concentraçăo de valores mais caros que a alternativa unimodal rodoviária (diferença percentual positiva).

Quanto à variação da distância de percurso da alternativa multimodal com relação a unimodal rodoviária, pode-se perceber através do gráfico apresentado na Figura 5.11, que a maior parte dos valores observados para as alternativas multimodais está associada com um aumento da distància com relação à alternativa unimodal rodoviária. Ao mesmo tempo, a variação da diferença de custo entre alternativa

\footnotetext{
22 No gráfico "Box Plot", pode-se observar onde estão concentrados os dados. No caso dos gráficos apresentados a caixa indica onde $90 \%$ das observaçỏs estão localizadas, sendo o traço transversal à caixa a indicação referente à localização da média das observações.
} 
multimodal e unimodal rodoviária, e a variação da distância, apresentam correlação positiva significativa (coeliciente de correlação igual a 0.46997).

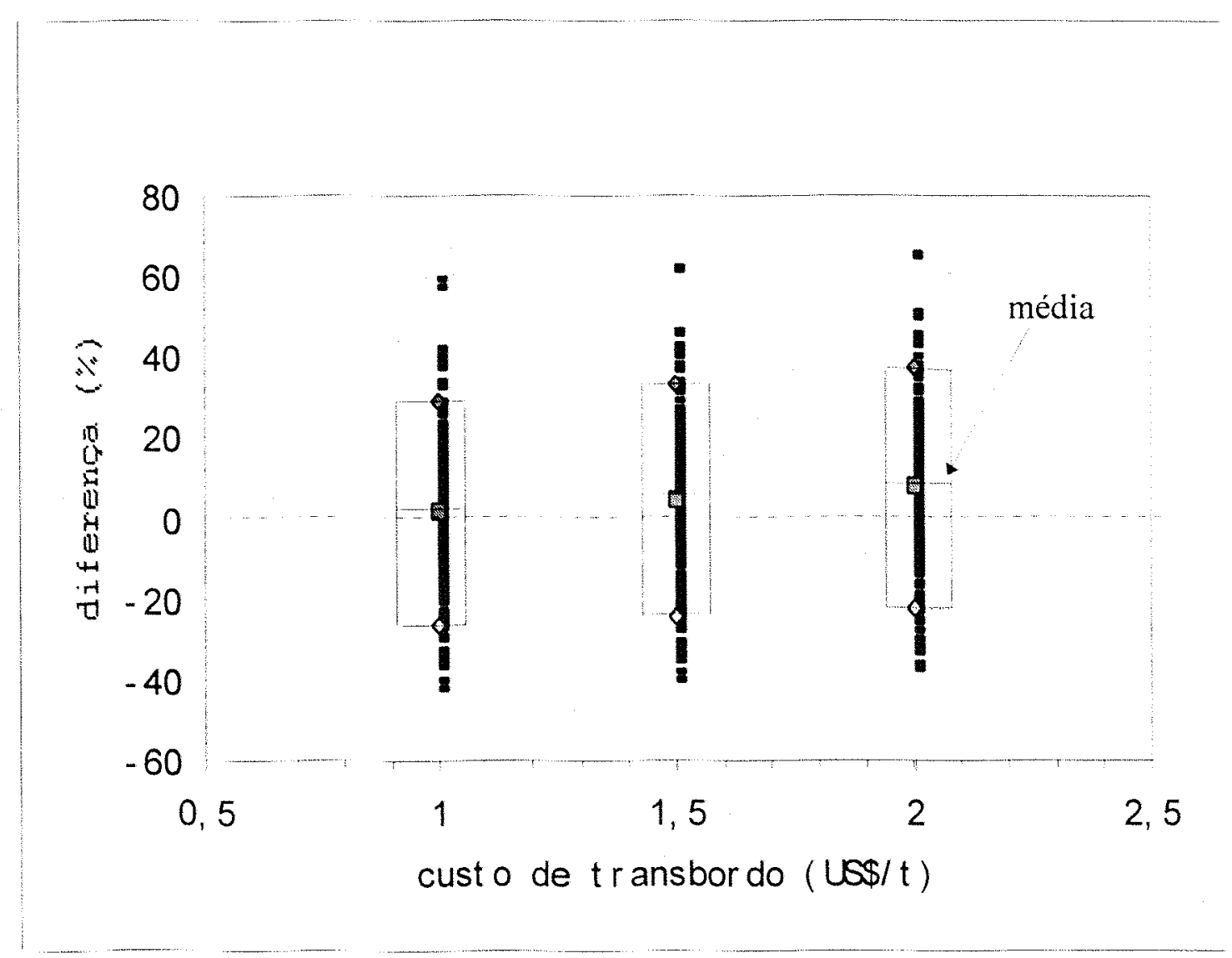

Figura 5.9 - Variação da diferença percentual entre a alternativa multimodal e a unimodal rodoviária, com relação à alteração do custo de transbordo. 

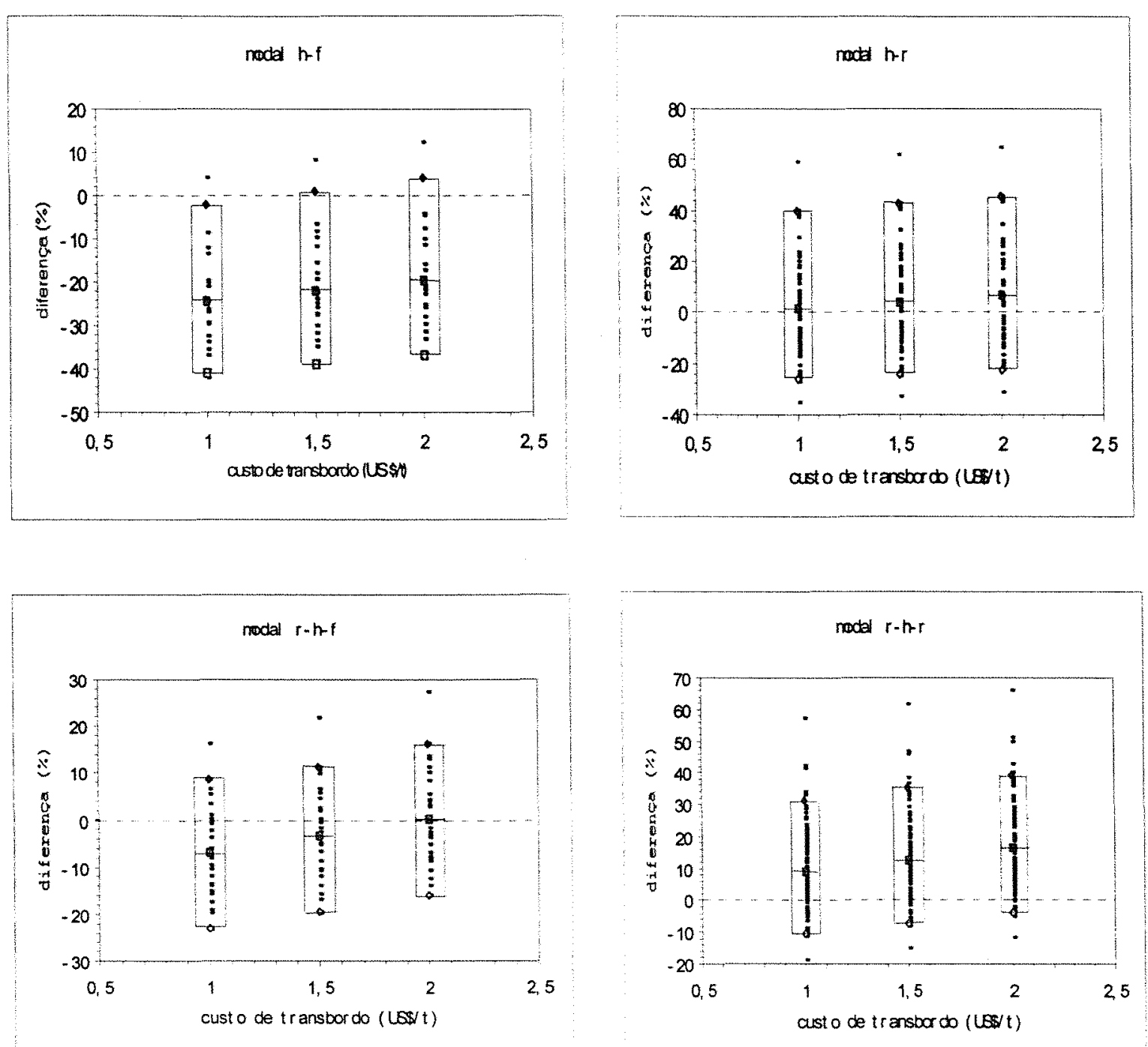

Figura 5.10 - Variação da diferença percentual entre a alternativa multimodal e a unimodal rodoviária, com relação à alteração do custo de transbordo, para cada alternativa de transporte. 


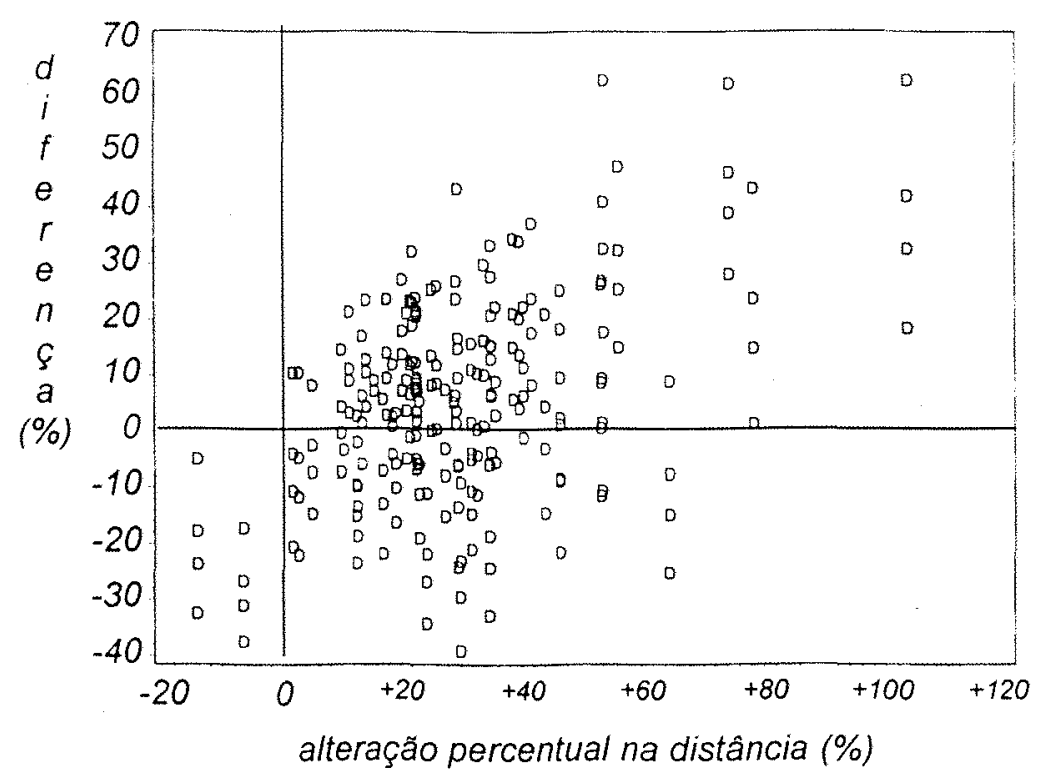

Figura 5.11 - Comportamento da variação da diferença de custo entre as alternativas multimodais e unimodal rodoviária, com relação a alteração da distância entre essas duas alternativas.

Uma outra representação que pode ilustrar a competitividade das alternativas multimodais istudas com relação ao transporte rodoviário é obtida através dos gráficos apresentados nas Figuras 5.12 e 5.13. Na Figura 5.12, pode-se visualizar o comportamento geral do frete das alternativas multimodais e da unimodal rodoviária. De forma geral, a alternativa multimodal apresentou valores de frete inferiores aos da unimodal rodoviária, entre as distâncias de $600 \mathrm{~km}$ a $1200 \mathrm{~km}$, não se observando um aumento da vantagem das alternativas multimodais com o aumento da distância rodoviriria. Por outro lado, desagregando a informação, segundo as alternativas multimodais (Figura 5.13), pode-se notar que a alternativa $\mathbf{r}-\mathbf{h}-\mathbf{r}$ apresenta a maioria dos valores acima daqueles correspondentes à alternativa rodoviária, independente da distância; a alternativa $\mathbf{r}-\mathbf{h}-\mathbf{f}$ apresenta vantagem para as distâncias entre $700 \mathrm{~km} \mathrm{e}$ $1200 \mathrm{~km} ;$ a alternativa h-r apresenta um maior número de valores menores que o frete rodoviario, com o aumento da distância; e a h-f apresenta valores menores que o frete rodoviirio, independente da distância. 
Conforme destacado no capítulo 2. cada modalidade de transporte possui características distintas $\mathrm{cm}$ termos de capacidade, velocidade. disponibilidade. confiabilidade e perdas. () usuário, diante das suas necessidades de movimentação de produtos, decorrentes das atividades de comercialização. exercerá um papel particular em termos de demanda por transporte. Assim sendo, as características de cada modalidade serão relacionadas com o seu preço ou valor do frete, exigindo-se compensações em função da qualidade do serviço prestado.

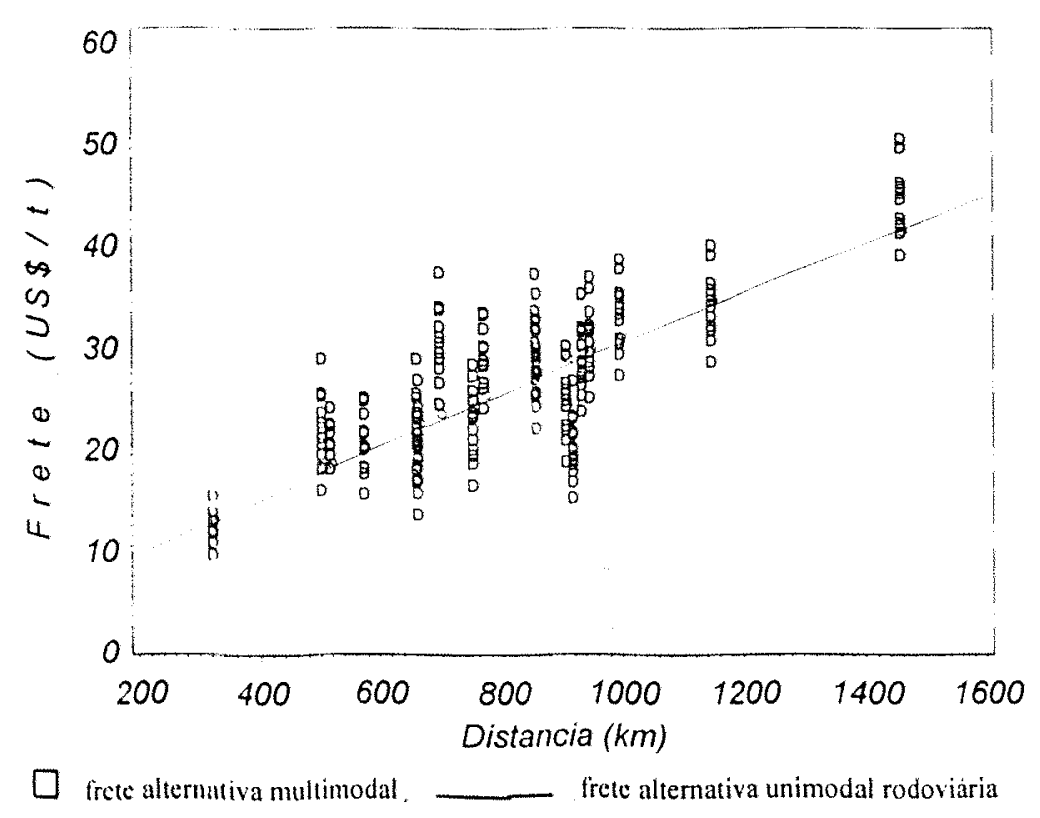

Figura 5.12 - Comportimento geral dos valores de frete (US\$/t) das alternativas multimodais e da unimodal rodoviária, com relação à distància da unimodal rodoviária. 

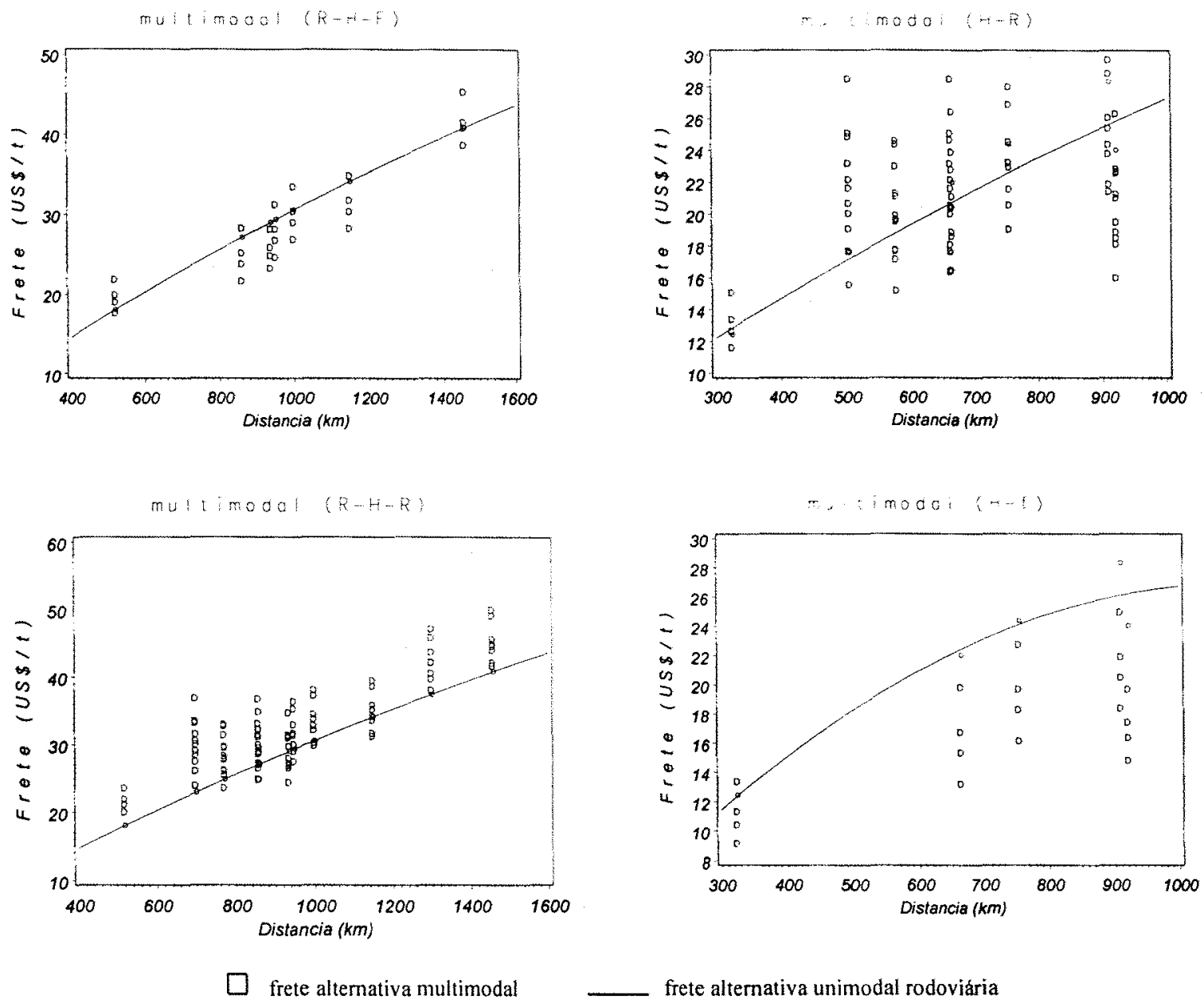

Figura 5.13 - Comportamento do valor de frete (US\$/t) da alternativa multimodal e da unimodal rodoviária, com relação à distância da unimodal rodoviária, para cada alternativa de transporte.

Através da observação dos dados apresentados anteriormente, percebe-se que a alternativa multimodal h-f, apresenta uma vantagem nítida com relação à alternativa unimodal rodoviária. No entanto, a sua utilização restringe-se a cargas oriundas de pólos localizados junto à hidrovia, o que é ainda o caso de apenas uma indústria de óleo de soja, que utiliza a referida alternativa de transporte para escoar o farelo de soja com destino a Santos.

Os demais produtos estudados, soja em grão e milho em grão, necessariamente estão associados às alternativas multimodais $\mathbf{r}-\mathbf{h}-\mathbf{f}$ ou $\mathbf{r}-\mathbf{h}-\mathbf{r}$. Neste caso, as vantagens dessas alternativas ficam dependentes de determinadas variáveis, como por exemplo, o 
par de origem/destino, a variação na distância de percurso da alternativa multimodal com relação à alternativa unimodal rodoviária, o custo de transbordo, e as condições de operação da hidrovia (custos hidroviários).

Soma-se ainda a estes elementos as compensações de preço exigidas pelo usuário, estabelecidas mediante uma avaliação dos custos indiretos advindos do uso de uma determinada alternativa de transporte. Por exemplo, em função da disponibilidade do transporte hidroviário ser bem menor que a do rodoviário, a empresa deve programar com antecedência as suas movimentações, implicando em um custo, que deve ser compensado pela economia advinda do uso dessa modalidade.

As economias apresentadas nas Tabelas 5.19 e 5.20 devem ser suficientes para compensar os custos indiretos da utilização da alternativa multimodal e ainda oferecer uma vantagem atrativa aos demandantes de transporte, em sua maioria, acostumados com as particularidades da alternativa unimodal rodoviária. 


\section{CONCLUSÕES}

$\mathrm{Na}$ caracterização da oferta do serviço de transporte hidroviário, foram detectados três tipos básicos de empresas atuantes: as empresas especializadas no transporte, as empresas que transportam carga própria e aquelas que além de transportar carga própria, prestam serviços a terceiros. Essas empresas de transporte hidroviário, com uma exceção, trabalham exclusivamente com soja. milho e farelo de soja, o que representa um fator negativo, pois as movimentações ocorrem em um sentido apenas, sem a exploração de cargas de retorno. Essa característica não é observada, por exemplo, nos EUA, onde as empresas de transporte atuam com vários produtos.

Quanto à conduta com relação ao usuário, não foram observados contratos de longo prazo, ustabelecidos entre os demandantes e os prestadores do serviço. Com exceção das cargas próprias das empresas, os prestadores trabalham com uma expectativa de demanda bastante incerta, fator esse que influencia a intensidade de utilização das instalações e embarcações.

Constatou-se que a intensidade de utilização do equipamento, representada pelo número de viagens realizadas por ano e pela porcentagem de carregamento (o quanto é efetivamente utilizado da capacidade de transporte), mostrou-se determinante dos custos unitários (US\$/t.km) tanto para o comboio simples como para o duplo. Foram observadas variações de até $54 \%$ do custo unitário de transporte entre uma situação de operação real e uma situação ótima. A diferença entre os valores considerados em projeto e os que as empresas estão obtendo, advém basicamente de um número menor de viagens realizadas por ano e pela não exploração de cargas de retorno, o que afeta a porcentagem de carregamento. Assim sendo, investimentos realizados no equipamento 
de transporte, sem a devida conjugação de cargas, podem se tornar inviáveis, mesmo considerando-se a existência de algumas vantagens comparativas.

O comboio duplo, com relação ao simples, apresentou, na média, custos unitários (US $\$ / \mathrm{t} . \mathrm{km}$ ) 37\% menores. No entanto, a sua utilização não tem sido permitida por alegação de problemas de segurança. A economia observada pode gerar vantagem bastante interessante para a atividade, o que não deveria ser desprezado, a menos que estudos viessem provar a completa impossibilidade de utilização desse equipamento. Esse problema mostra-se também relevante quando se observa o tipo de embarcação utilizado pelas empresas, que na maioria dos casos foi dimensionado para operar como comboio duplo. Fica, então, a recomendação para trabalhos futuros relacionados com a determinação de tipos de embarcação mais econômicas.

O sistema de operação da hidrovia Tietê-Paraná mostrou-se capaz de influenciar as atividades das empresas nos seguintes aspectos: o regime de funcionamento das eclusas: a restrição ao uso do comboio duplo (já comentada) e a cobrança da taxa de percurso.

$\mathrm{O}$ regime de funcionamento de eclusas afeta diretamente o número total de viagens realizadas por ano, que. como foi visto, afeta os custos unitários de transporte. Foi constatado que as eclusas têm apresentado período de inoperância bastante superior, ao observado em hidrovias internacionais. to mesmo tempo, o número de viagens por ano, considerado como possivel pelas empresas, é inferior ao considerado pelos projetos de navegação da hidrovia. Desta forma. pode-se considerar que esse aspecto da operação da hidrovia deve ser, pelo menos, reavaliado.

Quanto à taxa de utilização da hidrovia, os valores cobrados não são superiores aos cobrados, por exemplo, nos EUA. No entanto, a cobrança dessa taxa deve ser respaldada por uma série de análises que avaliem os impactos sobre a atividade, em especial sobre a competitividade do transporte hidroviário. Ao se comparar os valores cobrados nas hidrovias norte-americanas, deve-se ponderar que a atividade nesse país é tradicional e ocorre em uma escala no mínimo 100 vezes maior que a nacional. Recomenda-sc, então, a realização de trabalhos que avaliem a forma e os possíveis 
impactos da cobrança de taxas de utilização da hidrovia. considerando-se os benefícios indiretos sociais, advindos da intensificação do uso de uma alternativa de transporte. comprovadamente mais cliciente na utilização de recursos não renováveis e menos geradora de custos externos.

Os atuais demandantes do transporte hidroviário são basicamente empresas comercializadoras de soja e milho e indústrias produtoras de óleo de soja. As empresas exportadoras de soja em grão, que optaram pelo uso da alternativa hidroviária, internalizaram essa atividade. Já as indústrias de óleo optaram pela contratação do transporte hidroviário de terceiros, atualmente trabalhando com contratos de curto prazo e utilizando a alternativa rodoviária como referencial-limite de preço. A existência de contratos apenis de curto prazo entre os agentes econômicos da atividade pode indicar que a expectativa de alta atratividade do serviço oferecido não está se concretizando, e talvez esse seja um ponto de explicação da alta defasagem entre valores estimados e realizados de volumes de cargas.

Dois tipos bísicos de fluxos dos produtos estudados foram detectados: as movimentações de soja em grão e farelo de soja para a exportação, e as movimentações de soja em grão e milho em grão para o mercado interno. A soja em grão com destino ao mercado interno tem sido utilizada por apenas uma indústria de óleo de soja localizada no Estado de São Paulo. O milho em grão tem sido movimentado dentro de um esquema de comercializaçĩo centralizado por uma empresa, que vende no Estado de São Paulo o milho produzido em Goiás. Pode-se assumir que o pequeno volume e a pulverização dos pontos de destino são fatores limitantes ao uso da alternativa hidroviária na distribuição de milho em grão e farelo de soja para o mercado interno, principalmente para a prodlução animal.

A competitividade da alternativa multimodal, que inclui a hidrovia, não foi seguramente incontestável, se apresentando dependente de uma série de variáveis, dentre clas o custo hidroviário, o tipo de alternativa multimodal disponível entre um determinado par origem/lestino e o aumento da distância com relação ao transporte rodoviário. Constatou-se que dependendo do desempenho da empresa na gestão das 
variáveis influenciadoras do seu custo unitário de transporte (US\$/t.km), em especial, a intensidade de utilização do equipamento, o serviço oferecido por ela será competitivo ou não.

Para o caso das rotas com destino a Santos, a alternativa multimodal mais competitiva com relação à unimodal rodoviária foi a que não incluiu a modalidade rodoviária em nenhuma das pontas. Considerando-se a situação de custo hidroviário mais próxima da realidade, a diferença da alternativa hidro-ferroviária com relação à rodoviária foi de $-11,68 \%$. No entanto, dos produtos que se destinam à exportação por Santos, apenas o farelo de soja produzido às margens da hidrovia pode utilizar essa alternativa. A soja em grão necessariamente deve utilizar a modalidade rodoviária na coleta junto à regiño produtora. Neste caso, a vantagem com relação à alternativa unimodal rodoviária varia de pequena a inexistente, principalmente no caso da modalidade rodo-hidro-rodo.

Para as rotas com destino às cidades do Estado de São Paulo, a alternativa hidroferroviária também foi mais atrativa. Em segundo lugar aparece a alternativa rodohidro-ferroviária, que neste caso foi mais atrativa que a hidro-rodoviária. A inclusão da modalidade rodoviária reduziu a competitividade da alternativa multimodal frente à alternativa unimodal rodoviária. Ressalta-se que determinados pares de origem/destino analisados nĩo possuem ligação por todas as alternativas multimodais, sendo assim, a competitividade frente ao transporte rodoviário varia conforme cada caso analisado. Muitas das cidades. consideradas como destino, possuem como alternativa ao transporte unimodal rodoviário apenas o transporte multimodal rodo-hidro-rodo, o que limita bastante a possibilidade dessas cidades serem supridas por um sistema de transporte mais barato que a modalidade rodoviária.

Outro aspecto importante, principalmente para as empresas de transporte hidroviário, é a competitividade associada com cada terminal de desembarque. Como os terminais na hidrovia Tietê-Paraná, em sua maioria, são privados, cada empresa está restrita a utilizar um conjunto próprio de alternativas multimodais. Segundo os dados levantados, os terminais que estiveram associados a rotas hidroviárias mais baratas que o 
transporte rodoviário direto, foram os de conexão ferroviária (Panorama, Presidente Epitácio e Pederneiras). (Os terminais de conexão apenas rodoviária, na média das alternativas multimodais que por eles passaram, não se mostraram atrativos.

Ao se visualizar a competitividade do ponto de vista da distância percorrida pela alternativa unimodal rodoviária. percebe-se que não ocorreu uma relação direta entre aumento da distância e diminuição da competitividade dessa alternativa. Para os casos em que a alternativa multimodal $\mathbf{r}-\mathbf{h}-\mathbf{r}$ e $\mathbf{r}-\mathbf{h}-\mathbf{f}$, apresentou alguma vantagem, isto ocorreu em uma distância aproximada entre 800 e $1200 \mathrm{~km}$. A alternativa multimodal hr, por outro lado, foi a única que aumentou a sua competitividade com o aumento da distância da alternativa unimodal rodoviária. tendo mais opções vantajosas acima dos $900 \mathrm{~km}$. Já a alternativa multimodal $\mathbf{h}$-f apresentou vantagem independente da distância.

As capacidades de transporte de cada alternativa multimodal, comparadas à capacidade do concorrente rodoviário, não foram consideradas na análise, o que deve ser ressaltado como uma limitação. Pode ocorrer que uma das alternativas estudadas apresente uma restrição de capacidade, que implique em um aumento dos custos de transporte a partir do aumento do volume atraído. No entanto, essa informação não está atualmente disponível, o que inclusive pode ser sugerido como assunto de trabalhos futuros.

A decisão do demandante dos serviços de transporte sobre a alternativa a ser utilizada viabiliza-se no médio prazo, principalmente, quando essa decisão inclui o transporte multimodal. Ao contrário do transporte rodoviário. cujo serviço é em sua maioria contratado diariamente no mercado "spot", a alternativa hidroviária exige uma programação estratégica e antecipada. Desta forma, as vantagens a serem obtidas pela utilização de alternativas multimodais devem ser suficientes para justificar tal programação estratégica e, ainda. ressarcir os custos indiretos associados com o uso desse serviço. Segundo os dados levantados no presente trabalho, não é possível afirmar se as vantagens encontradiss para determinadas rotas multimodais são ou não suficientes para atender os requisitos apresentados anteriormente. Esse também pode ser um objeto para novos estudos. que fundamentalmente deveriam determinar os atributos 
considerados como importantes na seleção de alternativas de transporte e dos possiveis descontos necessários para se compensar diferenças na qualidade do serviço.

Dada a maior complexidade da tomada de decisão com respeito ao transporte multimodal, um sistema de informação sobre as características dos diferentes serviços e de seus preços, seria uma outra recomendação decorrente deste trabalho. Como foi apresentado, a competitividade da alternativa multimodal varia caso a caso, ficando difícil para uma empresa, individualmente, levantar e avaliar toda informação necessária. O sistema de informações sobre valores de frete seria ainda importante para a viabilização da avaliação da competitividade. considerando-se as variações sazonais de frete, o que nĩo foi possivel realizar no presente trabalho, dada a inexistência de dados sazonais, levantados sistematicamente sobre todas as rotas consideradas.

O presente trabalho foi realizado em um periodo de início de modificações estruturais no sistema de transporte nacional. em especial envolvendo a privatização por concessão das ferrovias federais, e a privatização de estradas rodoviárias, principalmente estaduais. Desta forma, existem perspectivas de diminuição de até $20 \%$ no valor do frete ferroviário e, por outro lado, aumento no valor do frete rodoviário. Também deve-se salientar a importância da privatização dos portos, em especial do porto de Santos, que está diretamente relacionado com a movimentação dos produtos estudados com destino a exportação. A melhoria desse porto e o aumento da participação deste nas exportações de farelo de soja. pode aumentar o volume de soja em grão e farelo de soja movimentados pela hidrovia com destino ì exportação. Essas modificações podem alterar os resultados. inclusive no sentido da melhoria da competitividade da alternativa multimodal que inclui a hidrovia Tietê-Parani.

Não obstante à possíveis modificações futuras, os principais elementos influenciadores da atividade de transporte hidroviário, foram aqui determinados e salientados, oferecendo ponto de partida e termo de comparação para novos trabalhos futuros. 


\section{ANEXO}

Tabela 1 - Distâncias referentes às origens e destinos, por alternativa multimodal e unimodal rodoviária, com destino à Santos.

\begin{tabular}{|c|c|c|c|c|c|c|c|}
\hline \multirow{4}{*}{ Origem - Destino } & \multicolumn{7}{|c|}{ Alternativa de transporte } \\
\hline & \multicolumn{6}{|c|}{ Multimodal } & \multirow{2}{*}{$\begin{array}{l}\text { Unimodal } \\
\text { rodoviário }\end{array}$} \\
\hline & Tipo & r 1 & r2 & $\mathrm{f}$ & h & total & \\
\hline & & \multicolumn{6}{|c|}{ distância $(\mathrm{km})$} \\
\hline Rio Verde - Sintos & $r-f$ & 459 & 0 & 895 & 0 & 1354 & 1000 \\
\hline Rio Verde - Santos & $r-h-f$ & 195 & 0 & 496 & 640 & 1331 & 1000 \\
\hline Rio Verde - Santos & $\mathrm{r}-\mathrm{h}-\mathrm{r}$ & 195 & 307 & 0 & 720 & 1222 & 1000 \\
\hline Jatai - Santos & $r-f$ & 378 & 0 & 895 & 0 & 1273 & 1150 \\
\hline Jatai - Santos & $\mathrm{r}-\mathrm{h}-\mathrm{f}$ & 240 & 0 & 496 & 640 & 1376 & 1150 \\
\hline Jatai - Santos & $r-h-r$ & 240 & 307 & 0 & 720 & 1267 & 1150 \\
\hline Rondonopolis - Santos & $r-f$ & 797 & 0 & 895 & 0 & 1692 & 1460 \\
\hline Rondonopolis - Santos & $r-h-f$ & 603 & 0 & 496 & 640 & 1739 & 1460 \\
\hline Rondonopolis - Santos & $r-h-r$ & 603 & 307 & 0 & 720 & 1630 & 1460 \\
\hline Sao Simao - Santos & $h-f$ & 0 & 0 & 496 & 640 & 1136 & 910 \\
\hline Sao Simao - Santos & $h-r$ & 0 & 307 & 0 & 720 & 1027 & 910 \\
\hline
\end{tabular}

onde: $\mathrm{rl}$ - conexão rodoviária de coleta, $\mathrm{r} 2$ - conexão rodoviária de distribuição, $\mathrm{f}$ ferroviäria e $\mathrm{h}$ - hidroviária. 
Tabela 2 - Distâncias referentes às origens e destinos, por alternativa multimodal e unimodal rodoviária.

\begin{tabular}{|c|c|c|c|c|c|c|c|}
\hline \multirow{4}{*}{ Origem - Destino } & \multicolumn{7}{|c|}{ Alternativa de transporte } \\
\hline & \multicolumn{6}{|c|}{ Multimodal } & \multirow{2}{*}{$\begin{array}{l}\text { Unimodal } \\
\text { rodoviário }\end{array}$} \\
\hline & Tipo & r 1 & r2 & f & h & total & \\
\hline & & \multicolumn{6}{|c|}{ distância $(\mathrm{km})$} \\
\hline Rio Verde - Osvaldo Cruz & $r-11-1$ & 195 & 0 & 127 & 410 & 732 & 520 \\
\hline Rio Verde - Osvaldo Cruz & $r-h-r$ & 195 & 98 & 0 & 344 & 637 & 520 \\
\hline Rio Verde - Descalvado & $r-h-r$ & 195 & 138 & 0 & 640 & 973 & 700 \\
\hline Rio Verde - Campinas & $r-l^{\infty}$ & 430 & 0 & 626 & 0 & 1056 & 860 \\
\hline Rio Verde - Campinas & $r-h-f$ & 195 & 0 & 227 & 640 & 1062 & 860 \\
\hline Rio Verde - Campinas & $r-h-r$ & 195 & 144 & 0 & 720 & 1059 & 860 \\
\hline Rio Verde - Tietê & $r-h-r$ & 195 & 210 & 0 & 640 & 1045 & 772 \\
\hline Rio Verde - Ourinhos & $r-h-f$ & 195 & 0 & 390 & 473 & 1058 & 936 \\
\hline Rio Verde - Ourinhos & $r-h_{1-r}$ & 195 & 152 & 0 & 640 & 987 & 936 \\
\hline Rio Verde - Mogi Guaçu & $r-h-r$ & 195 & 220 & 0 & 640 & 1055 & 858 \\
\hline Rio Verde - Mairinque & $r-1$ & 430 & 0 & 741 & 0 & 1171 & 950 \\
\hline Rio Verde - Mairinque & $r-11-f^{\circ}$ & 195 & 0 & 380 & 640 & 1215 & 950 \\
\hline Rio Verde - Mairinque & $r-11-r$ & 195 & 278 & 0 & 720 & 1193 & 950 \\
\hline Rio Verde - Paranagua & $r-11-r$ & 195 & 656 & 0 & 720 & 1571 & 1300 \\
\hline Sao Simão - Osvaldo Cruz & $h-l^{2}$ & 0 & 0 & 127 & 410 & 537 & 325 \\
\hline Sao Simão - Osvaldo Cruz & $h-r$ & 0 & 98 & 0 & 344 & 442 & 325 \\
\hline Sao Simão - Descalvado & $h-r$ & 0 & 138 & 0 & 640 & 778 & 505 \\
\hline Sao Simão - Campinas & $h-i$ & 0 & 0 & 227 & 640 & 867 & 665 \\
\hline Sao Simão - Campinas & $h-1$ & 0 & 144 & 0 & 720 & 864 & 665 \\
\hline Sao Simão - Campinas & $r+1$ & 235 & 0 & 626 & 0 & 861 & 665 \\
\hline Sao Simão - Tietè & $h-1$ & 0 & 210 & 0 & 640 & 850 & 577 \\
\hline Sao Simão - Ourinhos & $h-1$ & 0 & 0 & 390 & 473 & 863 & 921 \\
\hline Sao Simão - Ourinhos & $h=H^{\circ}$ & 0 & 152 & 0 & 640 & 792 & 921 \\
\hline Sao Simão - Mogi-Guaçu & $\ln -\mathbf{k}$ & 0 & 220 & 0 & 640 & 860 & 663 \\
\hline Sao Simão - Mairinque & $h=h^{2}$ & 0 & 0 & 380 & 640 & 1020 & 755 \\
\hline Sao Simão - Mairinque & $h-r$ & 0 & 278 & 0 & 720 & 998 & 755 \\
\hline Sao Simão - Mairinque & $r=r$ & 235 & 0 & 741 & 0 & 976 & 755 \\
\hline
\end{tabular}

onde: $\mathrm{r} 1$ - conexão rodoviária de coleta, $\mathrm{r} 2$ - conexão rodoviária de distribuiçăo, f - conexão ferroviária c h - conexão hidroviaria. 
Tabela 3 - Valores calculados para o custo unitário de transporte hidroviário (US\$/t.km) para o comboio simples de $2200 \mathrm{t}$.

\begin{tabular}{|c|c|c|c|c|}
\hline \multirow[b]{2}{*}{$\begin{array}{l}\text { no de } \\
\text { yidagens }\end{array}$} & \multicolumn{4}{|c|}{ is de carregamento } \\
\hline & 47,5 & 50 & 62,5 & 75 \\
\hline 10 & 0.08167 & 0.07762 & 0.06221 & 0.05194 \\
\hline 11 & 0.07501 & 0.07129 & 0.05715 & 0.04772 \\
\hline 12 & 0.06946 & 0.06602 & 0.05293 & 0.04421 \\
\hline 13 & 0.06477 & 0.06156 & 0.04936 & 0.04123 \\
\hline 14 & 0.05074 & 0.05773 & 0.04630 & 0.03868 \\
\hline 15 & 0.05725 & 0.05442 & 0.04365 & 0.03647 \\
\hline 16 & 0.05420 & 0.05152 & 0.04133 & 0.03454 \\
\hline 17 & 0.05151 & 0.04896 & 0.03929 & 0.03284 \\
\hline 18 & 0.04912 & 0.04669 & 0.03747 & 0.03132 \\
\hline 19 & 0.04697 & 0.04465 & 0.03584 & 0.02996 \\
\hline 20 & 0.04505 & 0.04282 & 0.03437 & 0.02874 \\
\hline 21 & 0.04330 & 0.04117 & 0.03305 & 0.02764 \\
\hline 22 & 0.04172 & 0.03966 & 0.03184 & 0.02663 \\
\hline 23 & 0.04027 & 0.03828 & 0.03074 & 0.02572 \\
\hline 24 & 0.03894 & 0.03702 & 0.02974 & 0.02488 \\
\hline 25 & 0.03772 & 0.03586 & 0.02881 & 0.02410 \\
\hline 26 & 0.03659 & 0.03479 & 0.02795 & 0.02339 \\
\hline 27 & 0.03555 & 0.03380 & 0.02716 & 0.02273 \\
\hline 28 & 0.03458 & 0.03288 & 0.02642 & 0.02211 \\
\hline 29 & 0.03368 & 0.03203 & 0.02574 & 0.02154 \\
\hline 30 & 0.03284 & 0.03123 & 0.02510 & 0.02101 \\
\hline 31 & 0.03205 & 0.03048 & 0.02450 & 0.02051 \\
\hline 32 & 0.03131 & 0.02978 & 0.02394 & 0.02004 \\
\hline 33 & 0.03062 & 0.02912 & 0.02341 & 0.01960 \\
\hline 34 & 0.02997 & 0.02850 & 0.02291 & 0.02919 \\
\hline 35 & 0.02935 & 0.02791 & 0.02244 & 0.01880 \\
\hline 36 & 0.02877 & 0.02736 & 0.02200 & 0.01843 \\
\hline 37 & 0.02822 & 0.02684 & 0.02159 & 0.01808 \\
\hline 38 & 0.02770 & 0.02634 & 0.02119 & 0.01775 \\
\hline 39 & 0.02720 & 0.02587 & 0.02081 & 0.01744 \\
\hline 40 & 0.02673 & 0.02543 & 0.02046 & 0.01714 \\
\hline 41 & 0.02629 & 0.02500 & 0.02012 & 0.01686 \\
\hline 42 & 0.02586 & 0.02460 & 0.01979 & 0.01659 \\
\hline 43 & 0.02546 & 0.02421 & 0.01949 & 0.01633 \\
\hline 44 & 0.02507 & 0.02384 & 0.01919 & 0.01609 \\
\hline 45 & 0.02470 & 0.02349 & 0.01891 & 0.01586 \\
\hline 46 & 0.02435 & 0.02316 & 0.01864 & 0.01563 \\
\hline 47 & 0.02401 & 0.02284 & 0.01838 & 0.01542 \\
\hline 48 & 0.02368 & 0.02253 & 0.01814 & 0.01521 \\
\hline 49 & 0.02337 & 0.02223 & 0.01790 & 0.01501 \\
\hline 50 & 0.02307 & 0.02195 & 0.01767 & 0.01482 \\
\hline 51 & 0.02278 & 0.02167 & 0.01745 & 0.01464 \\
\hline
\end{tabular}




\begin{tabular}{|c|c|c|c|c|}
\hline & .02251 & 0.02141 & 0.01724 & 0.01447 \\
\hline & 0.02224 & 0.02116 & 0.01704 & 0.01430 \\
\hline & 0.02199 & 0.02092 & 0.01685 & 0.01414 \\
\hline & 0.02174 & 0.02068 & 0.01666 & 0.01398 \\
\hline & 0.02150 & 0.02046 & 0.01648 & 0.01383 \\
\hline & 0.02127 & 0.02024 & 0.01631 & 0.01368 \\
\hline & 0.02105 & 0.02003 & 0.01614 & 0.01354 \\
\hline & 0.02084 & 0.01982 & 0.01597 & 0.01341 \\
\hline & 0.02063 & 0.01963 & 0.01582 & 0.01328 \\
\hline & 0.02043 & 0.01944 & 0.01567 & 0.01315 \\
\hline & 0.02024 & 0.01925 & 0.01552 & 0.01303 \\
\hline & 0.02005 & 0.01907 & 0.01538 & 0.01291 \\
\hline & 0.01987 & 0.01890 & 0.01524 & 0.01279 \\
\hline & 0.01969 & 0.01874 & 0.01510 & 0.01268 \\
\hline & 0.01952 & 0.01857 & 0.01497 & 0.01257 \\
\hline & 0.01935 & 0.01842 & 0.01485 & 0.01247 \\
\hline & 0.01919 & 0.01826 & 0.01473 & 0.01237 \\
\hline & 0.01904 & 0.01811 & 0.01461 & 0.01227 \\
\hline & 0.01889 & 0.01797 & 0.01449 & 0.01217 \\
\hline & 0.01874 & 0.01783 & 0.01438 & 0.01208 \\
\hline & 0.01860 & 0.01769 & 0.01427 & 0.01199 \\
\hline & 0.01846 & 0.01756 & 0.01417 & 0.01190 \\
\hline & 0.01832 & 0.01743 & 0.01406 & 0.01181 \\
\hline & 0.01819 & 0.01731 & 0.01396 & 0.01173 \\
\hline & 0.01806 & 0.01719 & 0.01386 & 0.01165 \\
\hline & 0.01793 & 0.01707 & 0.01377 & 0.01157 \\
\hline & 0.01781 & 0.01695 & 0.01368 & 0.01149 \\
\hline & 0.01769 & 0.01684 & 0.01359 & 0.01142 \\
\hline & 0.01758 & 0.01673 & 0.01350 & 0.01134 \\
\hline & 0.01746 & 0.01662 & 0.01341 & 0.01127 \\
\hline & 0.01735 & 0.01652 & 0.01333 & 0.01120 \\
\hline & 0.01725 & 0.01641 & 0.01325 & 0.01114 \\
\hline & 0.01714 & 0.01631 & 0.01317 & 0.01107 \\
\hline & 0.01704 & 0.01622 & 0.01309 & 0.01100 \\
\hline & 0.01694 & 0.01612 & 0.01301 & 0.01094 \\
\hline & 0.01684 & 0.01603 & 0.01294 & 0.01088 \\
\hline & 0.01675 & 0.01594 & 0.01287 & 0.01082 \\
\hline & 0.01665 & 0.01585 & 0.01279 & 0.01076 \\
\hline & 0.01656 & 0.01576 & 0.01272 & 0.01070 \\
\hline & 0.01647 & 0.01568 & 0.01266 & 0.01064 \\
\hline & 0.01638 & 0.01559 & 0.01259 & 0.01059 \\
\hline & 0.01630 & 0.01551 & 0.01253 & 0.01053 \\
\hline & 0.01621 & 0.01543 & 0.01246 & 0.01048 \\
\hline
\end{tabular}


Tabela 4 - Valores calculados para o custo unitário de transporte hidroviário (US\$/t.km) para o comboio duplo de $4400 \mathrm{t}$.

\begin{tabular}{|c|c|c|c|c|}
\hline \multicolumn{5}{|c|}{$\%$ de carregamento } \\
\hline $\begin{array}{c}\text { no. de } \\
\text { viagens }\end{array}$ & 47,5 & 50 & 62,5 & 75 \\
\hline 10 & 0.0501 & 0.0476 & 0.0382 & 0.0319 \\
\hline 11 & 0.0460 & 0.0438 & 0.0351 & 0.0294 \\
\hline 12 & 0.0427 & 0.0406 & 0.0326 & 0.0272 \\
\hline 13 & 0.0399 & 0.0379 & 0.0304 & 0.0255 \\
\hline 14 & 0.0374 & 0.0356 & 0.0286 & 0.0239 \\
\hline 15 & 0.0353 & 0.0336 & 0.0270 & 0.0226 \\
\hline 16 & 0.0335 & 0.0318 & 0.0256 & 0.0214 \\
\hline 17 & 0.0318 & 0.0303 & 0.0243 & 0.0204 \\
\hline 18 & 0.0304 & 0.0289 & 0.0232 & 0.0195 \\
\hline 19 & 0.0291 & 0.0277 & 0.0223 & 0.0186 \\
\hline 20 & 0.0279 & 0.0266 & 0.0214 & 0.0179 \\
\hline 21 & 0.0269 & 0.0256 & 0.0206 & 0.0172 \\
\hline 22 & 0.0259 & 0.0247 & 0.0198 & 0.0166 \\
\hline 23 & 0.0251 & 0.0238 & 0.0192 & 0.0161 \\
\hline 24 & 0.0243 & 0.0231 & 0.0186 & 0.0156 \\
\hline 25 & 0.0235 & 0.0224 & 0.0180 & 0.0151 \\
\hline 26 & 0.0228 & 0.0217 & 0.0175 & 0.0147 \\
\hline 27 & 0.0222 & 0.0211 & 0.0170 & 0.0143 \\
\hline 28 & 0.0216 & 0.0206 & 0.0166 & 0.0139 \\
\hline 29 & 0.0211 & 0.0200 & 0.0162 & 0.0136 \\
\hline 30 & 0.0206 & 0.0196 & 0.0158 & 0.0132 \\
\hline 31 & 0.0201 & 0.0191 & 0.0154 & 0.0129 \\
\hline 32 & 0.0196 & 0.0187 & 0.0151 & 0.0127 \\
\hline 33 & 0.0192 & 0.0183 & 0.0148 & 0.0124 \\
\hline 34 & 0.0188 & 0.0179 & 0.0145 & 0.0121 \\
\hline 35 & 0.0185 & 0.0176 & 0.0142 & 0.0119 \\
\hline 36 & 0.0181 & 0.0172 & 0.0139 & 0.0117 \\
\hline 37 & 0.0178 & 0.0169 & 0.0136 & 0.0115 \\
\hline 38 & 0.0175 & 0.0166 & 0.0134 & 0.0113 \\
\hline 39 & 0.0172 & 0.0163 & 0.0132 & 0.0111 \\
\hline 40 & 0.0169 & 0.0161 & 0.0130 & 0.0109 \\
\hline 41 & 0.0166 & 0.0158 & 0.0128 & 0.0107 \\
\hline 42 & 0.0164 & 0.0156 & 0.0126 & 0.0106 \\
\hline 43 & 0.0161 & 0.0153 & 0.0124 & 0.0104 \\
\hline 44 & 0.0159 & 0.0151 & 0.0122 & 0.0103 \\
\hline 45 & 0.0156 & 0.0149 & 0.0120 & 0.0101 \\
\hline 46 & 0.0154 & 0.0147 & 0.0119 & 0.0100 \\
\hline 47 & 0.0152 & 0.0145 & 0.0117 & 0.0099 \\
\hline 48 & 0.0150 & 0.0143 & 0.0116 & 0.0097 \\
\hline 49 & 0.0148 & 0.0141 & 0.0114 & 0.0096 \\
\hline 50 & 0.0147 & 0.02140 & 0.0113 & 0.0095 \\
\hline 51 & 0.0145 & 0.0138 & 0.0112 & 0.0094 \\
\hline 52 & 0.0143 & 0.0136 & 0.0110 & 0.0093 \\
\hline 53 & 0.0142 & 0.0135 & 0.0109 & 0.0092 \\
\hline
\end{tabular}




\begin{tabular}{lllll}
54 & 0.0140 & 0.0133 & 0.0108 & 0.0091 \\
55 & 0.0139 & 0.0132 & 0.0107 & 0.0090 \\
56 & 0.0137 & 0.0131 & 0.0106 & 0.0089 \\
57 & 0.0136 & 0.0129 & 0.0105 & 0.0088 \\
58 & 0.0134 & 0.0128 & 0.0104 & 0.0087 \\
59 & 0.0133 & 0.0127 & 0.0103 & 0.0086 \\
60 & 0.0132 & 0.0126 & 0.0102 & 0.0086 \\
61 & 0.0131 & 0.0124 & 0.0101 & 0.0085 \\
62 & 0.0130 & 0.0123 & 0.0100 & 0.0084 \\
63 & 0.0128 & 0.0122 & 0.0099 & 0.0083 \\
64 & 0.0127 & 0.0121 & 0.0098 & 0.0083 \\
65 & 0.0126 & 0.0120 & 0.0097 & 0.0082 \\
66 & 0.0125 & 0.0119 & 0.0097 & 0.0081 \\
67 & 0.0124 & 0.0118 & 0.0096 & 0.0081 \\
68 & 0.0123 & 0.0117 & 0.0095 & 0.0080 \\
69 & 0.0122 & 0.0116 & 0.0094 & 0.0080 \\
70 & 0.0121 & 0.0116 & 0.0094 & 0.0079 \\
71 & 0.0120 & 0.0115 & 0.0093 & 0.0078 \\
72 & 0.0120 & 0.0114 & 0.0092 & 0.0078 \\
\hline & & & &
\end{tabular}




\section{REFERÊNCIAS BIBLIOGRÁFICAS}

AGUIAR, D.R.D. Formação de preços na indústria brasileira de soja - 1982/1989. Piracicaba, 1990. 140p. Dissertação (M.S.) - Escola Superior de Agricultura "Luiz de Queiroz", Universidade de São Paulo.

BANCO CENTRAL DO BRASIL - BACEN. Boletim do Banco Central do Brasil. Brasília: BACEN, v.31, n.9, set. 1995. 482p. (suplemo estatístico)

BALAU, J.A.C. Dimensionamento de comboio fluvial para transporte de bauxita na região amazônica. In: NOVAES, A.G. Métodos de otimização - aplicações aos transportes. São Paulo: Edgard Blücher, 1978. cap. 18, p.357-78.

BARROS, G.S.C. Economia da Comercialização Agrícola. Piracicaba: FEALQ, 1987. 306p.

BEILOCK, K.R. \& CASAVANT, K. Perishables - The new intermodal battleground. American Journal of Agricultural Economics. v.66, n.5, p.651-656. 1984.

BENJAMIN, J. An analysis of mode choice for shippers in a constrained network with applications to just-in-time inventory. Transportation Research - B, v.24, n.3, p.229-45, 1990.

BIERMAN, D. E. \& RYDZKOWSKI, W. Contemporary problems of European waterways. Transportation quarterly, v.42, n.2, p.289-306, apr. 1988.

BONNOT, J. Le projet Rhin-Rhône: un dossier complet, détaillé. La CNR est techniquement en mesure d'engager les travaux à I'été 1994. Navigation Ports \& Industries. Strasbourg, n.17, p. 511, sep. 1993.

BRONZINI, M.S.; KINNISON, H.A.; PHILIP, C.E. \& DROBNY, C.J. Managing barge operations for improved productivity. Transportation Research Record, v.1015, p.10-6. 1985.

BTS - Bureau of transportation statistics. Transportation Statistics - Annual Report 1994. Washington: BTS-USDT, jan. 1994.

BURNQUIST, H.L., (coord.) Liberalização comercial: um fator de desenvolvimento do setor agrícola brasileiro. Brasília: IPEA, 1994. 216p. (Série Estudos de Políticas Agrícolas, Relatórios de Pesquisas (IPEA), 14)

BURG, H.B. \& DALEY, J.M. Transportation as perceived by shallow-draft water carriers: implications for improved marketing decisions. Transportation Research Record, v. 1015, p.1-5. 1985

CAIXETA FILHO, J.V. A modelagem de perdas no transporte de produtos agrícolas. Piracicaba, 1995. 112p. Tese (Livre-Docência) - Escola Superior de Agricultura "Luiz de Queiroz", Universidade de São Paulo. 
CHAIN Jr., M. Os caminhos do Mercosul - transporte fluvial em Mato Grosso e paises do Mercosul. Campo Grande: SEBRAE, 1995.

COMPANHIA ENERGÉTICA DE SÃO PAULO - CESP. Hidrovia Tietê-Paraná, integração e desenvolvimento regional. São Paulo: CESP, jul. 1992.

- Apresentação de parâmetros básicos para comparação indicativa entre os modais hidroviários $\mathbf{x}$ ferroviário $\mathbf{x}$ rodoviário. São Paulo: CESP, 1994. 35p.

Informações básicas da hidrovia Tietê-Paraná. São Paulo: CESP, 1995a. 22p.

- Hidrovia Tietê-Paraná - embarcações tipo-características e dimensões. São Paulo: CESP, mar. 1995b. 31p.

COHEN. M.D. A decision support system prototype for network problems. Cary: SAS institute Inc. 1984.

COUNCIL FOR AGRICULTURAL SCIENCE AND TECHNOLOGY. An approach to evaluation of rural transportation needs and problems in the United States. In: UNITED STATES SENATE. Report on a field study of problems in agricultural transportation and marketing. Washington: U.S. Government Printing Office, 1974. p. 9-27.

DASKIN, M.S. Logistics: An overview of the state of the art and perspectives on future research. Transportation Research - A, v.19A, n.5/6, p.383-393. 1985.

EASTMAN, S.E. Selected produtivity compararisons in surface freight transportation: inland water, rail, an d truck, 1955-1979. Transportation Research Record, v.880, p.22-26. 1982.

ELLWANGER, G. The internalisation of the external effects of transport. Rail International, p.9-15, may 1995.

EMPRESA DI: PORTOS DO BRASIL - THEMAG. Viabilidade da navegação no rio Piracicaba, no trecho compreendido entre a cidade de Piracicaba e a sua foz, no Rio Tietê. São Paulo: THEMAG, 1987. 268p. (Relatorio Final)

ESTRAZULAS, J.A. Projetos agrícolas e estudos especiais. São Paulo: BM\&F, 1996. $32 p$.

FEDELER, J.A. \& HEADY, E. O. Grain Marketing and Transportation Interdependencies: A National Model. American Journal of Agricultural Economics, v.58. n.2, p. 224-235, may 1976.

FERREIRA, L.R.: BURNQUIST, H.L. \& AGUIAR, D.R.D. Infraestrutura, comercialização e competitividade da agricultura brasileira. Brasília: IPEA, out. 1993. 63p. (Texto para Discussão $n^{\mathbb{Q} 318 \text { ) }}$

FNP CONSULTORIA \& COMÉRCIO. AgriAnual 96: Anuário estatístico da agricultura brasileira. Sĩo Paulo: FNP, 1996. 392p. 
FOWKES, A.S.I NASH,C.A. \& TWEDDLE. G. Investigating the marketing for intermodal freight technologies. Transportation Research-A. v.25, n.4, p.161-72. 1991.

GALLIMORE, W.W. Transporting food and agricultural products. In: USDA. Agricultural-food policy review: Perspectives for the 1980's. Washington: USDA, apr. 1981. p. 82-91.

GEIPOT - EMPRESA BRASILEIRA DE PLANEJAMENTO DE TRANSPORTE. Corredores de transporte Centro-Leste e Paraná - relatório. Brasília: GEIPOT, 1993. 188p.

. Anuário Estatístico dos Transportes. Brasília: GEIPOT, 1995. 266p.

GIL, H.C. Como elaborar projetos de pesquisa. São Paulo: Atlas, 1988. 159p.

GUALDA, N D F. Modelo para análise da competitividade entre alternativas de transporte no estado de São Paulo. Revista Politécnica, v. 81, n.188, p.14-7, jul. 1985.

HAWNN, A. F. \& SHARP, F.M. Inland navigation systems analysis. Transportation Research Receord, v.636, p.8-13, 1977.

JOHNSON, M.A. Estimating the influence of service quality on transportation demand. American Journal of Agriculture Economic, v.58, n.3, p.496-503, aug. 1976.

JOHNSON, C. J. \& WOOD, D. F. Contemporary logistics. 4 ed. New York: Macmillan Publishing Company. 1990.579p.

KANAFANI, A.K. Transportation Demand Analysis. New York: Mcgraw Hill, 1983. $320 \mathrm{p}$.

KOO, W.W. \& LARSON, D.W. Transportation Models for Agricultural Products. Baulder: Westview Press, 1985.211p.

KOO,W.W.; THOMPSON, S.R. \& LARSON, D.W. Alternative transportation rate and cost structures: A linear programming model. In: KOO, W.W. \& LARSON, D.W. Transportation Models for Agriculture Products. Baulder: Westview Press, 1985. cap. 7, p.125-51.

KRAFT, G.; MEYER, J.R. \& VALETTE, J.P. The role of transportation in regional economic development. Lexington: Lexington Books, 1971. 129p.

KYLE. R.A. Intermodalism and Improved Transportation Productivity. Transportation Research Record, v. 763, p.1-2. 1980.

LICIO, A. \& CARBUCCI, R. Agricultura e os corredores de transporte multimodais. Revista de Política Agrícola, v.5, n.2, abr/maio-jun. 1996. p. 22-36.

I.IMA. S.M.A. Eficúcia da política de preços mínimos nos anos oitenta: o caso do milho no Brasil. Piracicaba, 1993, 157p. Dissertação (M.S.) - Escola Superior de Agricultura "Luiz de Queiroz", Universidade de São Paulo. 
MARCONI, M de A. \& LAKATOS, E.M. Técnicas de Pesquisa: planejamento e execussão de pesquisas, amostragens e técnicas de pesquisa, elaboração, análise e interpretação de dados. 2 ed. São Paulo: Atlas, 1990.

MELO, F. H. A crise da soja no Brasil. Conjuntura Econômica. out. 1994. p.44-5.

MICHAELS, G.H.; LEVINS, R.A. \& FRUIN, J.E. Rail/Truck competition for grain traffic in Mennesota: Implications for rate making. American Journal of Agriculture Economic, p. 276-279, may 1982.

MIKLIUS, W.; CASAVANT, K.L. \& GARROD, P.V. Estimation of demand for transportation of agricultural commodities. American Journal of Agriculture Economic, v.58, n.2, p. 217-223, may 1976.

MIN, H. International Intermodal Choices Via Chance-Constrained Goal Programming. Transportation Research - A, v.25, n.6, p.351-62. 1991.

NAVIGATION PORTS \& INDUSTRIES. Strasbourg, n.14, p.440-441. juil. 1994.

NOVAES, A. G. Demanda de transporte. São Paulo: Depto. de Engenharia de Transporte/POLI/USP, 1984. 159p.

REVISTA AVES \& OVOS. Previsão de consumo de milho - 1996. São Paulo, n.4, 1996.

RP Engenheiros Associados. Programa de Racionalização do Transporte de Cargas Agrícolas (PBQP). Estratégias para o Desenvolvimento Integrado da Agricultura Brasileira. cap. 3. Brasília: RP Engenheiros Associados, 1993. 247p.

ROBERTSON. A. C. Cost modeling: theory and practice. Transportation Research Record, v.758, p.75-81, 1980.

SANTO, B.R.E.; DAMASO,O.R. \& NASSAR, A.M. Evolução e perspectivas econômicas da produção de milho no Brasil. Revista de Política Agrícola, v.3, n.4, out-dez. 1994.

SAS INSTITUTE INC. SAS/OR User's Guide, version 6. 1 ed. Cary: Sas Institute Inc., $1989.479 \mathrm{p}$.

SOARES, M. G \& CAIXETA FILHO, J.V. Caracterização e custos do transporte rodoviário de cargas agrícolas. Piracicaba: DESR/ESALQ, 1996.

SOUZA, E.L.L. Cadeia agroindustrial do milho. In: MARQUES, P. V, coord. Anais do sexto curso de Comercialização de Commodities Agropecuárias. Piracicaba, ESALQ-DEPTO ECONOMIA E SOCIOLOGIA RURAL/FEALQ, 1995. p.159-80.

TOLEDO, P.E.N. Perspectivas do sistema hidroviário Tietê-Paraná no transporte do calcário agrícola no Estado de São Paulo. Piracicaba, 1982. 119p. Dissertação (M.S.) - Escola Superior de Agricultura "Luiz de Queiroz", Universidade de São Paulo. 
TROCCOLI, I.R. Primeira safra de milho no Centro-Sul, superou as expectativas. Revista Agroanalysis, v. 15, n.4, p.22-4. abr. 1995.

VEITH. M.T. \& BRONZINI, M.S. Commodity-flow and multimodal transportation analysis for inland waterway planning. Transportation Research Receord, v.636, p.8-13, 1977.

VITALE, J.E. Economic feasibility of transporting western coal on the New York State barge canal system. Transportation Research Record, v.763, p.27-33, 1980.

WAGNER, H. M. Pesquisa Operacional. 2 ed. Rio de Janeiro: Prentice-Hall do Brasil, 1986. 851p.

WRIGHT, C. L. Análise cconômica de transporte e armazenagem de grãos - Estudo do corredor de exportação de Paranaguá. Brasília: GEIPOT, 1980. 187p.

YIN, R.K. Case Study Research: design and methods. 6 ed. Newbury Park: SAGE Publications Inc., 1988. 165p. 


\section{APÊNDICE}

\section{Programa utilizado no processamento da rota Rio Verde-Santos.}

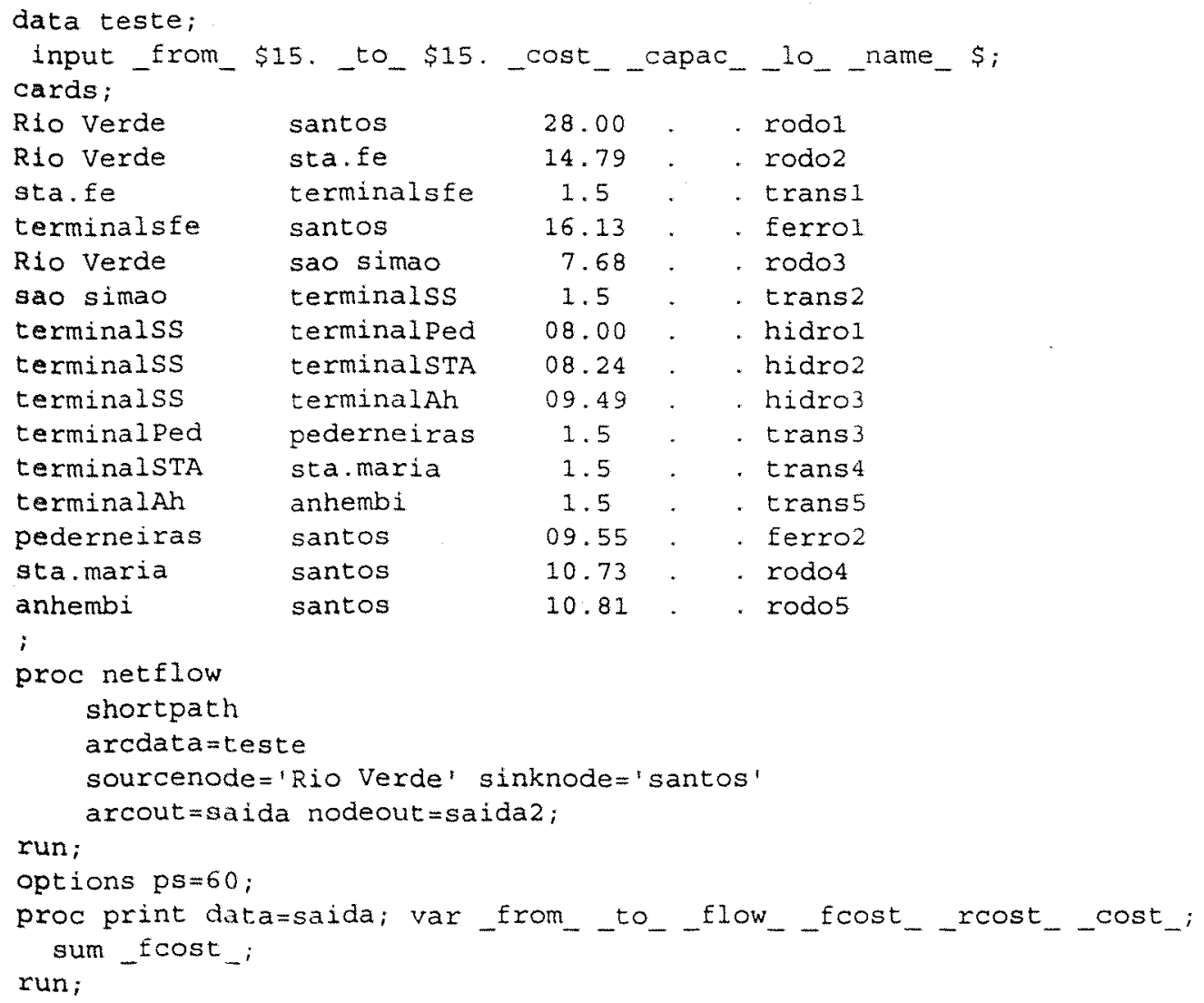

Saída de resultados do SAS, referente ao processamento do programa apresentado acima

$\begin{aligned} \text { OBS } & \text {-FROM } \\ 1 & \text { terminalAh } \\ 2 & \text { terminalped } \\ 3 & \text { Rio Verde } \\ 4 & \text { terminalsfe } \\ 5 & \text { pederneiras } \\ 6 & \text { sta.maria } \\ 7 & \text { anhembi } \\ 8 & \text { Rio Verde } \\ 9 & \text { Rio Verde } \\ 10 & \text { terminalsTa } \\ 11 & \text { terminalss } \\ 12 & \text { terminalss } \\ 13 & \text { sao simao } \\ 14 & \text { terminalss } \\ 15 & \text { sta.fo }\end{aligned}$

$\begin{array}{lc}\text { TO_- } & \text { FLOW } \\ \text { anhembi } & 0 \\ \text { pederneiras } & 0 \\ \text { santos } & 1 \\ \text { santos } & 0 \\ \text { santos } & 0 \\ \text { santos } & 0 \\ \text { santos } & 0 \\ \text { sao simao } & 0 \\ \text { sta. fe } & 0 \\ \text { sta.maria } & 0 \\ \text { terminalah } & 0 \\ \text { terminalped } & 0 \\ \text { terminalss } & 0 \\ \text { terminalsta } & 0 \\ \text { tarminalsfe } & 0\end{array}$

- FCOST
0
0
28
0
0
0
0
0
0
0
0
0
0
0
0
$\Rightarrow====$
28

$\operatorname{RCOST}_{-} \quad \quad \operatorname{COST}$

$\begin{array}{rr}. & 1.50 \\ . & 1.50 \\ 4.42 & 28.00 \\ 0.23 & 16.13 \\ 1.65 & 9.55 \\ 2.98 & 10.73 \\ . & 10.81 \\ . & 7.68 \\ . & 14.79 \\ . & 1.50 \\ . & 9.49 \\ . & 8.00 \\ . & 1.50 \\ . & 8.24 \\ & 1.50\end{array}$




\section{QUESTIONÁRIO}

\section{Caro Sr. <CONTATO $>$}

As informaçòes solicitadas no presente questionário se reterem a demanda da <NOME> pelo transporte de milho em grto. em especifico para os serviços de transporte contratados de tcrceiros.

1. Quais seriam as rotas e as respectivas modalidades (rodoviária, ferroviária, hidroviairia) utilizadas no transporte do milho demandado pela «apelidow?

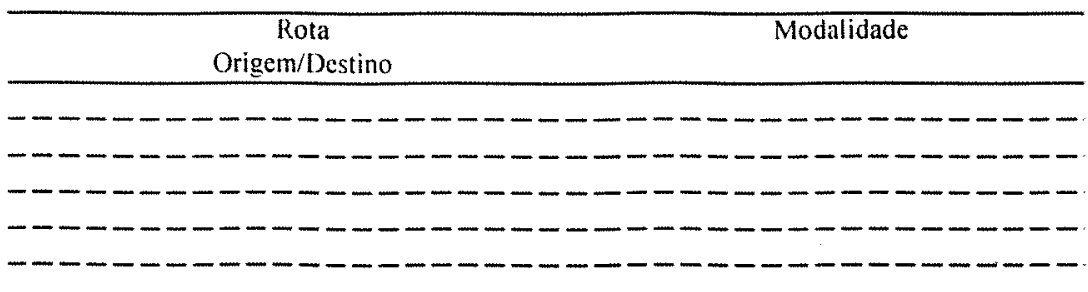

2. Qual a quantidade média demandada por mês de milho em grão pela «apelidon?

3. Se vocì fosse relatar os problemas com o transporte do milho em grào, quais seriam os principais aspectos a destacar ?

4. Na sua opiniaðo o aspecto mais importante de um serviço de transporte é

5. Na contratação de uma transportadora para a movimentaçðo de milho em grăo, qual é o grau de importància (1 a 5$)$ de cada um dos atributos apresentados abaixo?

\begin{tabular}{|c|c|c|c|}
\hline $\begin{array}{l}\text { I totalmente sem } \\
\text { importància }\end{array}$ & $\begin{aligned} 2= & \text { sem importância em } \\
& \text { certas situaçdes }\end{aligned}$ & $3=$ indiferente & $\begin{aligned} 4= & \text { importante em } \\
& \text { certas situaçðes }\end{aligned}$ \\
\hline
\end{tabular}

- tempo da empresa no mercado

()

- prazo de entrega

- idade da frota

- seguro contra acidentes e roubo de carga

()

- especialização no transporte de milho

- perdas e danos à carga

- visita de agentes promocionais de venda

- ter referèncias sobre scrviços anteriores prestados pela transportadora

( )

- frota própria

- prestar o serviço de ponta a ponta

- disponibilidade para alcnder transporte de cargas năo programadas

( ) com antecedencia

- pontualidade na entruga 
6. De cada par de alternativas de serviço de transporte, assinale aquela que você escolheria entre "A" ou "B". Faça a escolha em relação a todos os pares. mesmo que nào esteja muito convicto de sua preferència.

\begin{tabular}{|c|c|c|c|}
\hline $\begin{array}{c}\text { frete (US\$) } \\
\text { tempo em trinsito (horas) } \\
\text { entrega no tempo certo }(\%) \\
\text { perdas e danos }(\%)\end{array}$ & $\begin{array}{l}30 \\
12 \\
90 \\
10\end{array}$ & $\begin{array}{c}\text { frete (US\$) } \\
\text { tempo em trânsito (horas) } \\
\text { entrega no tempo certo }(\%) \\
\text { perdas e danos }(\%)\end{array}$ & $\begin{array}{r}30 \\
60 \\
100 \\
1\end{array}$ \\
\hline$(A)$ & & (B) & \\
\hline $\begin{array}{c}\text { frete (US } \$) \\
\text { tempo em trànsito (horas) } \\
\text { entrega no tempo certo }(\%) \\
\text { perdas e danos }(\%) \\
\end{array}$ & $\begin{array}{l}30 \\
12 \\
90 \\
10 \\
\end{array}$ & $\begin{array}{c}\text { frete (US\$) } \\
\text { tempo em trànsito (horas) } \\
\text { entrega no tempo certo }(\%) \\
\text { perdas e danos }(\%)\end{array}$ & $\begin{array}{r}27 \\
60 \\
100 \\
1 \\
\end{array}$ \\
\hline (A) & & (B) & \\
\hline $\begin{array}{c}\text { frete (US\$) } \\
\text { tempo em trinsito (horas) } \\
\text { entrega no tempo certo }(\%) \\
\text { perdas e danos }(\%)\end{array}$ & $\begin{array}{l}30 \\
12 \\
90 \\
10\end{array}$ & $\begin{array}{c}\text { frete (US\$) } \\
\text { tempo em trànsito (horas) } \\
\text { entrega no tempo certo }(\%) \\
\text { perdas e danos }(\%)\end{array}$ & $\begin{array}{r}24 \\
60 \\
100 \\
1\end{array}$ \\
\hline (A) & & (B) & \\
\hline $\begin{array}{c}\text { frete (US\$) } \\
\text { tempo em trilusito (horas) } \\
\text { entrega no tempo certo }(\%) \\
\text { perdas c danos }(\%)\end{array}$ & $\begin{array}{l}30 \\
12 \\
90 \\
10\end{array}$ & $\begin{array}{c}\text { frete (US\$) } \\
\text { tempo em trânsito (horas) } \\
\text { entrega no tempo certo }(\%) \\
\text { perdas e danos }(\%)\end{array}$ & $\begin{array}{r}15 \\
60 \\
100 \\
1\end{array}$ \\
\hline (A) & & (B) & \\
\hline
\end{tabular}

7. No cálculo do custo total de transporte do milho em grão para a «apelido», são considerados outros elementos além do frete e seguro? Por exemplo, custos extras ocasionados pelo não cumprimento dos prazos estabelecidos.

Se sim, quais seriam esses elementos
( ) Sim
( ) Nă

8. Para duas determinndas rotas de transporte. a sua escolha, quais seriam os valores pagos pelo frete nos meses em que a «apelido» contratou o serviço de transporte de milho em grão?

\begin{tabular}{|c|c|c|}
\hline \multicolumn{3}{|c|}{ Rotal } \\
\hline \multirow{3}{*}{\multicolumn{2}{|c|}{$\begin{array}{l}\text { Origem/Destino } \\
\text { Modalidade de transporte } \\
\text { Distância }(\mathrm{km})\end{array}$}} & $:$ \\
\hline & & \\
\hline & & $:$ \\
\hline Mes & $\begin{array}{l}\text { Valor do frete } \\
\text { (USS/t) }\end{array}$ & $\begin{array}{c}\text { Quantidade } \\
\text { total } \\
\text { transportad } \\
a(t) \\
\end{array}$ \\
\hline \multicolumn{3}{|l|}{ Janeiro } \\
\hline \multicolumn{3}{|l|}{ Fevereiro } \\
\hline \multicolumn{3}{|l|}{ Marco } \\
\hline \multicolumn{3}{|l|}{ Abril } \\
\hline \multicolumn{3}{|l|}{ Maio } \\
\hline \multicolumn{3}{|l|}{ Junho } \\
\hline \multicolumn{3}{|l|}{ Julho } \\
\hline \multicolumn{3}{|l|}{ Agosto } \\
\hline \multicolumn{3}{|l|}{ Setembro } \\
\hline \multicolumn{3}{|l|}{ Outubro } \\
\hline \multicolumn{3}{|l|}{ Novembro } \\
\hline Dezcinbro & & \\
\hline
\end{tabular}

\begin{tabular}{l|l|l|}
\hline $\begin{array}{l}\text { Origem/Destino } \\
\text { Modalidade de transporte }\end{array}$ \\
Distância (km)
\end{tabular}

9. Outros comentários pertinentes 